\author{
UNIVERSIDADE DE SÃO PAULO \\ FACULDADE DE CIÊNCIAS FARMACÊUTICAS \\ Programa de Pós-Graduação em Ciência dos Alimentos \\ Área de Concentração: Bromatologia
}

\title{
IMPACTO NO METABOLISMO DE CÉLULAS DE CÂNCER COLORRETAL TRATADAS COM PECTINAS DE MAMÃO PAPAIA, in vitro, SOB INIBIÇÃO QUÍMICA E BIOQUÍMICA DA EXPRESSÃO DE GAL-3
}

Rodrigo Guimarães Lopes

\author{
Dissertação para obtenção do Título de Mestre \\ Orientador: Prof. Dr. João Paulo Fabi
}

SÃO PAULO - SP

2019 



\author{
UNIVERSIDADE DE SÃO PAULO \\ FACULDADE DE CIÊNCIAS FARMACÊUTICAS \\ Programa de Pós-Graduação em Ciência dos Alimentos \\ Área de Concentração: Bromatologia
}

IMPACTO NO METABOLISMO DE CÉLULAS DE CÂNCER COLORRETAL TRATADAS COM PECTINAS DE MAMÃO PAPAIA, in vitro, SOB INIBIÇÃO QUÍMICA E BIOQUÍMICA DA EXPRESSÃO DE GAL-3

\author{
Rodrigo Guimarães Lopes \\ Versão Original \\ Dissertação para obtenção do Título de Mestre \\ Orientador: Prof. Dr. João Paulo Fabi
}

SÃO PAULO - SP

2019 
Autorizo a reprodução e divulgação total ou parcial deste trabalho, por qualquer meio convencional ou eletronico, para fins de estudo e pesquisa, desde que citada a fonte.

O presente trabalho foi realizado com apoio da Coordenação de Aperfeiçoamento de Pessoal de Nível Superior - Brasil (CAPES) Código de Financiamento 001

Ficha Catalográfica elaborada eletronicamente pelo autor, utilizando o programa desenvolvido pela Seção Técnica de Informática do ICMC/USP e adaptado para a Divisão de Biblioteca e Documentação do Conjunto das Químicas da USP

Bibliotecária responsável pela orientação de catalogação da publicação: Marlene Aparecida Vieira - CRB - 8/5562

L864i

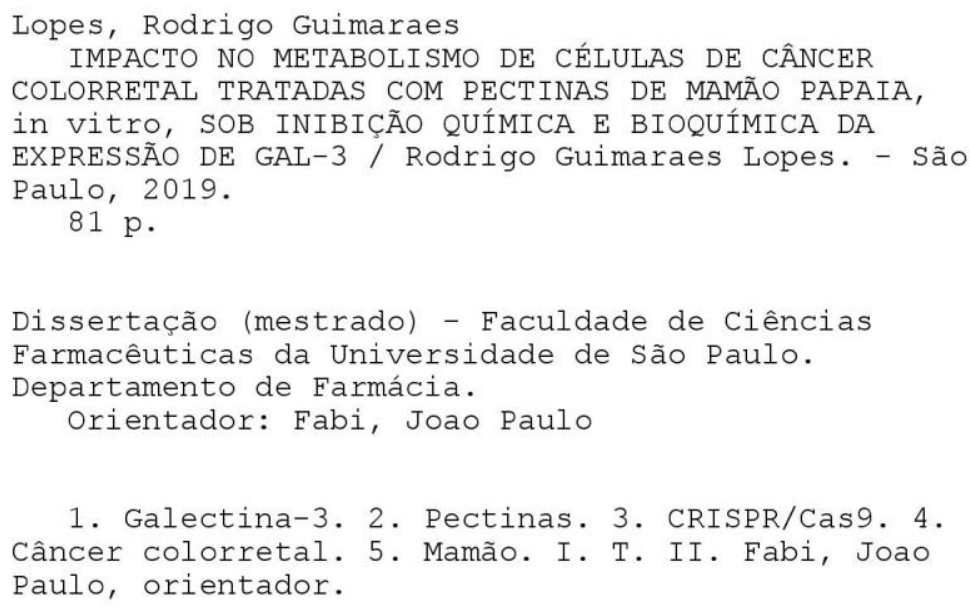


Rodrigo Guimarães Lopes

IMPACTO NO METABOLISMO DE CÉLULAS DE CÂNCER COLORRETAL TRATADAS COM PECTINAS DE MAMÃO PAPAIA, in vitro, SOB INIBIÇÃO QUÍMICA E BIOQUÍMICA DA EXPRESSÃO DE GAL-3

Comissão Julgadora da Dissertação para obtenção do Título de Mestre

Prof. Dr. João Paulo Fabi

Orientador/Presidente

1ํe examinador

$2^{\circ}$ examinador

3ำexaminador

$4^{\circ}$ examinador

São Paulo, de de 2019. 

"Primeiramente, esforçar-se para a formação do caráter! Primeiramente, esforçar-se para manter-se no verdadeiro caminho da razão! Primeiramente, criar o intuito do esforço! Primeiramente, respeitar acima de tudo! Primeiramente, conter ímpeto de agressão!" Dojo-Kun - Código de conduta Karateca 



\section{Agradecimentos}

Não há pessoa que seja mais digna de estar no topo dos meus agradecimentos que minha companheira Larissa Cardoso Paz. Ao longo destes três duríssimos anos, você foi quem esteve mais próxima de todo o processo de transição do Rodrigo de 2016, para o Rodrigo que hoje escreve este texto. Você esteve ao meu lado em cada lágrima derramada, em cada desabafo, em cada celebração, em cada conquista. Faltam palavras no meu vocabulário para expressar o tamanho do meu carinho, amor e gratidão por você ser tão amável, alegre, paciente, solícita e companheira comigo. A você, a plenitude dos meus pensamentos.

À minha família, Lucimar, Carlos, Felipe, Gabriel, Luciana, vó Cícera, vó Dolores, vô José, Cleusa, Orlando, Bruna e Cláudia, meu amor e gratidão também. Vocês são a essência do que me torna cidadão hoje, e se cheguei onde cheguei, foi porque tive a base que vocês me proporcionaram.

Ao Colégio Satélite, em especial à minha eterna professora de biologia, Edna Boniolo, por terem estimulado meu senso crítico, e por garantirem minha base educacional para que hoje eu pudesse estar caminhando sobre os ombros, e por entre os gigantes. Foi no ambiente desta grande escola que eu fiz amizades que faço questão de carregar para onde eu for. Agradeço com indescritível carinho ao lann Longhini, Wayner Guimarães e Renato França. Se eu sou quem eu sou hoje, foi porque tive a dádiva de ter vocês como parte da minha fundação enquanto ser humano. Eu não seria metade de quem eu sou hoje, sem vocês.

Às Faculdades Oswaldo Cruz por terem expandido os horizontes do meu conhecimento e, assim como o Colégio Satélite, garantido que eu pudesse hoje estar onde estou. Ricardo Serafim, Patrícia Yamaoka, Márcia Sussermann, Professora Bia, Renata Teixeira e Gabriel Arini, cada um de vocês contribuiu de alguma forma para a minha caminhada, e tenho grande carinho por cada um de vocês. Ao Pedro Lucas de Araújo também reservo imensa gratidão e carinho pelo companheirismo e solicitude.

À Universidade de São Paulo, por permitir que eu pudesse estar tão próximo do árduo processo de produção de conhecimento. Tânia, Lúcia, Luciene, Aline, Samira, Janayra, Raíssa, Victor, Ellen, Mayara, Mayra e professora Isabel, saibam que vocês também ocupam fração significativa da minha história. 
Aos meus colegas e alunos do Hexag: Minhoca, Renata, Lucas, Arthur, Pedro, Vinícius, Júlia, Heider, Nina, Lígia, Luana Mender, Ana Cristina e Rebeca. Vocês me fizeram sentir na pele que o conceito de família não se delimita à consanguinidade. Não é nenhum exagero dizer que eu amo a cada um de vocês, e essa batalha teria sido imensamente mais dura do que foi, não fosse pela presença de vocês durante esses três longos anos. Cada segundo junto de vocês foi de leveza, de tranquilidade, aprendizado e alto-astral. Eu sou eternamente grato a vocês.

Aos meus colegas de treino, com ênfase ao Sensei Ivaldo, ao Fábio e ao Mateus. Vocês reforçaram todos os valores que quero construir ao longo da vida através do Karatê. Muito obrigado por garantirem que eu seja alguém de quem me orgulho.

Ao Matheus Verne por seu profissionalismo, disposição e amizade. Você entende melhor do que ninguém quão pesados foram estes três anos para mim, e sua compaixão, carinho e paciência foram essenciais para que hoje eu enxergasse a mim e ao mundo da forma como vejo hoje.

Por fim, dedico este último parágrafo com grande carinho ao meu orientador e amigo João Paulo Fabi. Você acreditou em mim desde o começo, sempre me apoiando e confiando no meu potencial. Eu não teria crescido tanto como profissional, se eu não tivesse um referencial como você para seguir. Gratidão não é uma palavra que defina com plenitude a honra que foi ter você como parte fundamental desse processo.

Cada um de vocês foi essencial para que eu fosse quem sou hoje. Muito, muito obrigado por cada segundo que vocês me proporcionaram com a companhia de vocês. 


\section{RESUMO}

LOPES, R. G. Impacto no metabolismo de células de câncer colorretal tratadas com pectinas de mamão papaia, in vitro, sob inibição química e bioquímica da expressão de GAL-3. 2019. Pp. 81. Dissertação (Mestrado) Faculdade de Ciências Farmacêuticas, Universidade de São Paulo, São Paulo, 2019.

O câncer atualmente figura entre uma das principais causas de morte no mundo e, dentre os diversos tipos diferentes de tumores, destaca-se o colorretal (CCR). Estudos apontam forte correlação entre sedentarismo e alto consumo de produtos de origem animal associados à baixa ingestão de vegetais, frutas e leguminosas, resultando no baixo consumo de fibras solúveis, componentes amplamente presentes em frutos carnosos, como é o caso do mamão. Dentre as fibras solúveis dos frutos, destacam-se as pectinas, polissacarídeos que podem apresentar atividade antitumoral possivelmente devido à capacidade de interação com a galectina-3, uma proteína humana cuja superexpressão está intimamente relacionada ao desenvolvimento e metástase de células cancerosas. Além disso, indícios prévios sugerem a possibilidade da interação das pectinas com receptores transmembrana como os do tipo toll-like, interferindo nas vias de sinalizações celulares e, consequentemente, interferindo no desenvolvimento e progressão do câncer colorretal. Sendo assim, este projeto busca elencar o impacto promovido pela ação das frações solúveis em água de pectinas da polpa do mamão papaia em células de câncer colorretal, in vitro, produzindo efeitos anti-proliferativos. Para tanto, foram realizadas inibições químicas da galectina-3 e do receptor Toll-Like Receptor-4 em linhagens celulares de câncer colorretal HCT116 e HT29, bem como o nocaute gênico da expressão de galectina-3 da linhagem HCT116, através da técnica CRISPR/Cas9. Os resultados obtidos reforçam a relação dose-dependente entre a fração solúvel em água de pectinas de mamão papaia com a diminuição da viabilidade de células tumorais, in vitro, além de sugerir que haja uma via independente da interação dos polissacarídeos com a galectina-3 que contribua para o efeito observado.

Palavras-chave: Galectina-3, Pectinas, CRISPR/Cas9, Câncer colorretal, Mamão. 

LOPES, R. G. Impacts on the metabolism of colorectal cancer cells treated with papaya pectins, in vitro, under chemical and biochemical inhibition of GAL-3 expression. 2019. Pp. 81. Dissertação (Mestrado) - Faculdade de Ciências Farmacêuticas, Universidade de São Paulo, São Paulo, 2019.

\begin{abstract}
Cancer nowadays stands as one of the main causes of death worldwide and, amongst the different types of tumors, colorectal cancer (CRC) stands out. Studies show a strong correlation between sedentary lifestyle and high intake of animal products associated with low consumption of soluble fibers, nutrients that are present in fleshy fruits, such as papayas. Among the fruits' soluble fibers, pectins may show antitumoral activities possibly due to its high capability of interacting with galectin-3. Galectin-3 is a human protein whose overexpression is related to the development of cancerous cells and metastasis. Additionally, previous findings indicate the possibility of an interaction between pectins and transmembrane receptors of tumor cells such as the toll-like ones, intervening on the signaling pathways and, thus, dampening the development and progression of colorectal cancer. Therefore, this research aims to investigate on the impacts promoted by the water soluble fractions of papaya pulp pectins over colorectal cancer cells, in vitro, producing anti-proliferative effects. For this purpose, chemical inhibitions of galectin-3 and Toll-Like Receptor-4, and also the knockout of GAL-3 through CRISPR/Cas9 method were conducted in colorectal cancer cell lineages HCT116 and HT29. The results obtained reinforce the dosedependent relationship between water soluble fractions of papaya pectins and the reduction of the tumor cells' viability, in vitro, while also suggesting that there is an independent pathway of the interaction between papaya pectin and galectin3 that contributes to the observed effect.
\end{abstract}

Keywords: Galectin-3, Pectins, CRISPR/Cas9, Colorectal cancer, Papaya. 



\section{LISTA DE ABREVIATURAS}

AKT: Protein Kinase B - Proteína Quinase B

bak: B-cell lymphoma-2 homologous antagonist - Antagonista homólogo de linfoma de células $B$ número 2

bax: B-cell lymphoma-2-associated X protein - Proteína $X$ associada ao linfoma de células $B$ número 2

BF: Bright Field - Campo claro

Cas-9: CRISPR Associated protein 9 - Proteína associada ao CRISPR número 9

CCR: Câncer Colorretal

CD-14: Cluster of differentiation 14 - Cluster de diferenciação número 14

CDK-1: Cyclin-Dependent Kinase 1- Quinase dependente de ciclina

CRC: Colorectal Cancer - Câncer colorretal

crRNA: CRISPR RNA

CRISPR: Clustered Regularly Interspaced Short Palindromic Repeats -

Grupamentos de Repetições Curtas e Palindrômicas Regularmente Interespaçadas

DMEM: Dulbecco's Modified Eagle Medium - Meio Eagle modificado por Dulbecco

DMH: 1,2-Dimetil-Hidrazina

DPC: Dias Pós-Colheita

DSB: Double-Strand Break - Quebra da fita dupla

dsRNA: double-stranded RNA - RNA de fita dupla

DSS: Dextran Sulfato de Sódio

ELISA: Enzyme-Linked Immunosorbent Assay - Ensaio de Imunossorção

Enzimaticamente Ligado

FA: Fração Ácida

FACS: Fluorescence Activated Cell Sorting - Triagem de Células Ativada por Fluorescência

FBS: Fetal Bovine Serum - Soro Bovino Fetal

FITC: Fluorescein Isothiocyanate - Isotiocianato de Fluoresceína

FSA: Fração Solúvel em Água

FSO: Fração Solúvel em Oxalatos

GAL-3: Galectina-3

GFP: Green Fluorescent Protein - Proteína Fluorescente Verde

gRNA: guide RNA - RNA guia

HDR: Homology Directed Repair - Reparo Dirigido por Homologia 
HRP: Horseradish peroxidase - Peroxidase de Raíz-forte

HTCP: High Temperature Citrus Pectin - Pectina de Citros após Alta Temperatura

INCA: Instituto Nacional de Câncer José de Alencar Gomes da Silva

LogMW: Log Molecular Weight - Log de Peso Molecular

LPS: Lipopolissacarídeo

MCP: Modified Citrus Pectin - Pectina de Citros Modificada

MTT: Brometo de 3-(4,5-dimetiltiazol-2-il)-2,5-difeniltetrazólio

NAcLac: N-Acetil-Lactosamina

NF-кB: Necrosis Factor кB - Fator de Necrose кB

RFP: Red Fluorescent Protein - Proteína Fluorescente Vermelha

PAM: Protospacer Adjacent Motif - Sítio Adjacente Protoespaçante

PM: Peso Molecular

PTEN: Phosphatase and Tensin Homolog - Homólogo de Fosfatase e Tensina

RIPA: Radioimmunoprecipitation Assay - Ensaio de Radioimunoprecipitação

SDS-PAGE: Sodium dodecil sulfate-polyacrylamide gel electrophoresis -

Eletroforese em gel de poliacrilamida-dodecil sulfato de sódio

T0: Tratamento 0 - Fração Solúvel em Água + N-Acetil-Lactosamina / Resatorvid

T1: Tratamento 1 - Fração Solúvel em Água

T2: Tratamento 2 - Fração Solúvel em Água + N-Acetil-Lactosamina

T3: Tratamento 3 - Fração Solúvel em Água + Resatorvid

T4: Tratamento 4 - Fração Solúvel em Água + N-Acetil-Lactosamina + Resatorvid

TLR4: Toll-Like Receptor 4 - Receptor tipo Toll número 4

TNF- $\alpha$ : Tumor Necrosis Factor $\alpha$ - Fator de Necrose Tumoral $\alpha$

Tr: Tempo de Retenção

TRITC: Carboxytetramethylrhodamine Isothiocyanate - Isotiocianato de

Carboxitetrametilrodamina 


\section{SUMÁRIO}

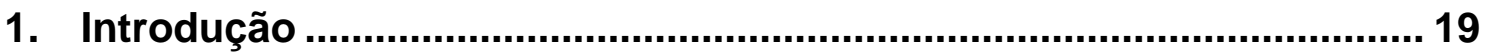

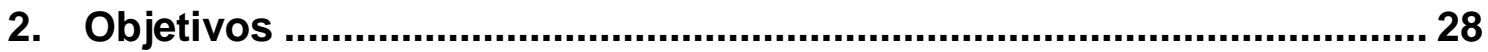

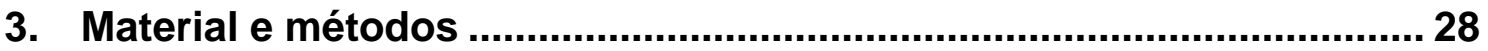

3.1. Amostras de mamão papaia …………………………………………....... 28

3.2. Extração e purificação das pectinas do material celular de mamões

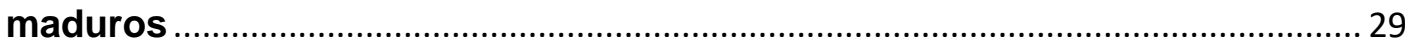

3.3. Ensaios de caracterização da pectina de mamão papaia......................... 29

3.3.1. Composição em monossacarídeos da pectina do mamão ............................. 29

3.3.2. Determinação da homogeneidade e peso molecular de polissacarídeos da

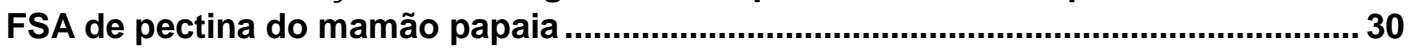

3.3.3. Determinação do teor de proteínas pelo método de Bradford ...................... 30

3.3.4. Determinação da concentração de compostos fenólicos totais pelo método

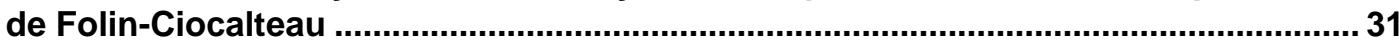

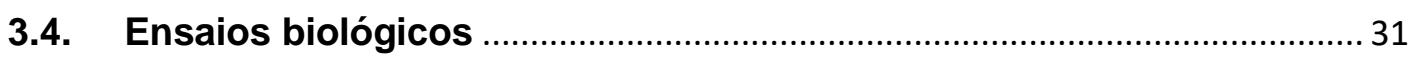

3.4.1. Cultivo celular e contagem de células viáveis .......................................... 31

3.4.2. Inibições químicas in vitro da GAL-3 e do TLR4 ....................................... 32

3.4.3. Ensaio colorimétrico de viabilidade celular (redução do MTT) ..................... 33

3.4.4. Curva padrão de crescimento populacional ............................................... 34

3.4.5. Knock-out da expressão de TLR4 e Galectina-3 das linhagens HCT116 e

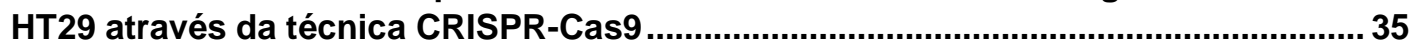

3.4.6. Isolamento de linhagens fluorescentes por citometria de fluxo (FACS Cell Sorting) 36

3.4.7. Western Blotting

3.4.8. Tratamentos da linhagem HCT116 KO para expressão de GAL-3 com

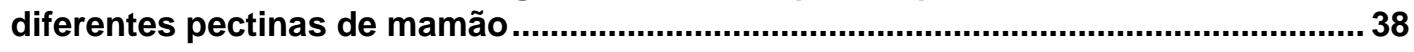

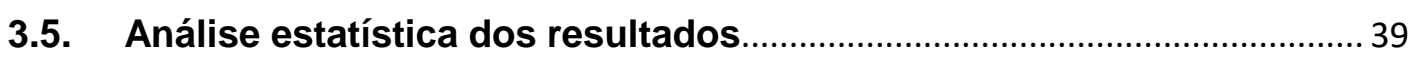

4. Resultados e Discussão................................................................... 40

4.1. Extração e purificação das pectinas da parede celular de mamões

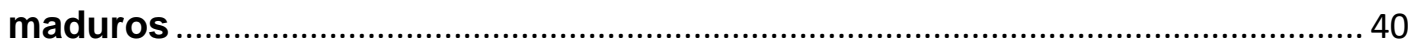

4.2. Composição em monossacarídeos da pectina do mamão ...................... 40

4.3. Determinação da homogeneidade e peso molecular de polissacarídeos da FSA de pectina do mamão papaia ..................................... 43

4.4. Determinação do teor de proteínas pelo método de Bradford................ 45

4.5. Determinação da concentração de compostos fenólicos totais pelo

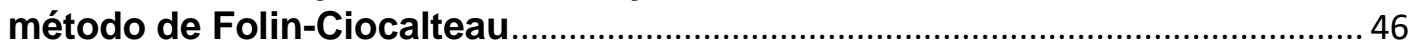

4.6. Inibições químicas in vitro da GAL-3 e do TLR4 ..................................... 47

4.6.1. Tratamento 0 : Inibidores químicos........................................................... 47

4.6.2. Efeito dos tratamentos concomitantes (T1, T2, T3 e T4) em HCT116 .......... 49 
4.6.3. Efeito dos tratamentos concomitantes (T1, T2, T3 e T4) em HT29 ..............51

4.6.4. Comparação entre os tratamentos e as linhagens celulares .......................53

4.6.5. População celular final após tratamentos concomitantes (T1, T2, T3 e T4)

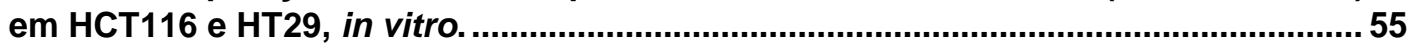

4.7. Knock-out gênico da expressão de GAL-3 e TLR4 via CRISPR-Cas9, e seleção celular por citometria de fluxo (FACS) .................................................. 57

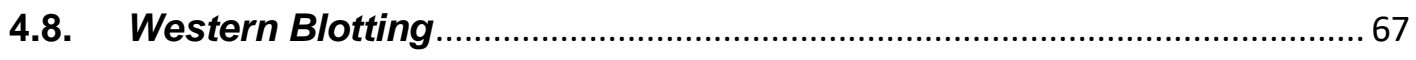

4.9. Tratamentos da linhagem HCT116 GAL-3 KO com diferentes pectinas

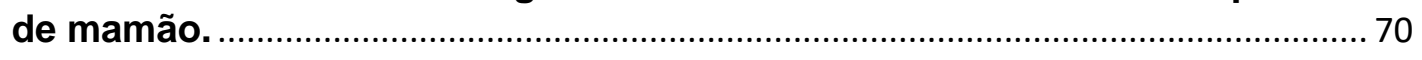

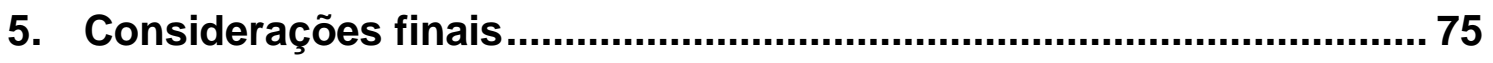

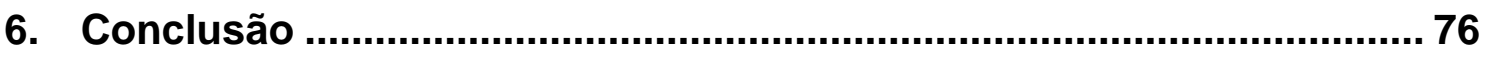

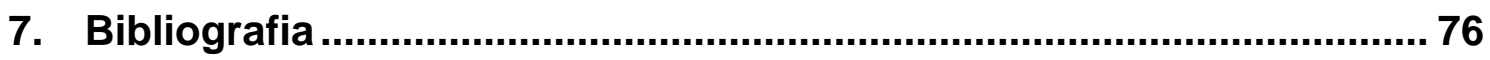




\section{Introdução}

A sociedade moderna, especialmente em países dos continentes americanos, possui um estilo de vida bastante característico com pouca prática de exercícios físicos, baixo consumo de vegetais, frutas e leguminosas, e alta ingestão de produtos de origem animal (BRUCE et al., 2000). Tais hábitos aparentam contribuir para o desenvolvimento de doenças associadas ao estilo de vida, as chamadas doenças crônicas não transmissíveis (BODE e DONG, 2009). Dentre estas, destacam-se os diversos tipos de cânceres, sendo 0 colorretal comumente associado ao estilo de vida acima descrito (GATOF, D., 2002). Em 2018, o câncer colorretal ocupava o terceiro lugar nas estatísticas mundiais de incidência, e o segundo lugar em mortes causadas por câncer (Bray, et al. 2018). Dados publicados pelo INCA (Instituto Nacional de Câncer José Alencar Gomes da Silva) indicam um risco estimado de 16,83 e 17,90 novos casos para cada 100 mil homens e mulheres, respectivamente no biênio 20182019 (INCA, 2018).

O câncer colorretal é uma doença que acomete, mais frequentemente, as porções sigmoide e descendente do intestino grosso e sua progressão advém do surgimento de adenomas pequenos que, quando não removidos, podem evoluir para carcinoma (LEVINE et al. 2006). BRUCE et al. (2000) sugerem que a dieta ocidental contribui para o desenvolvimento de câncer colorretal (CCR) a partir do fornecimento excessivo de moléculas energéticas (triacilgliceróis e glicose, por exemplo) que, associados ao baixo gasto energético característico do sedentarismo, estimulam proliferação celular e promovem microambiente de constante estresse oxidativo, que pode ser agravado por quadro de disbiose, conforme indicado por MYLES (2014).

A sequência de eventos que envolvem a progressão adenoma-carcinoma pode se dar através de duas importantes vias que afetam a expressão tanto genes supressores de tumores (como APC e TP53), como oncogenes (KRAS, PI3KCA, BRAF e NRAS). No primeiro caso, alterações mutagênicas podem ocorrer através de instabilidade cromossômica, originada a partir da duplicação ou deleção de trechos cromossômicos, correspondendo a $85 \%$ dos casos registrados de CRC. Já no segundo caso, as mutações podem ocorrer por instabilidade em microssatélites, correspondente a 15\% dos casos, não sendo incomum os dois eventos ocorrerem de forma concomitante (STRUM, 2016). Em 
ambos os casos, além de alterações nos genes responsáveis pela supressão e progressão de tumores, podem estar presentes alterações nos mecanismos genéticos de reparo do DNA, bem como modificações de ordem epigenética, podendo ser herdadas por outras gerações (MARKOWITZ e BERTAGNOLLI, 2009).

Dentre as várias modificações bioquímicas que as células de câncer colorretal apresentam quando comparadas com células normais do epitélio intestinal, diversos estudos apontam que as células de câncer colorretal superexpressam uma proteína pró-proliferativa e pró-metastática chamada galectina-3 (GAL-3). Existe uma evidente correlação entre o desenvolvimento de células tumorais intestinais altamente produtoras de GAL-3 com a progressão do câncer e sua metástase (NEWLACZYL e YU, 2011). A GAL-3 é uma proteína ubíqua e largamente expressa em diversos tecidos humanos, incluindo células do sistema imunológico, células epiteliais e em neurônios sensoriais.

Em sua extremidade C-terminal, a proteína apresenta um domínio de reconhecimento de carboidratos (Carbohydrate Recognition Domain - CRD), ligado a um domínio $\mathrm{N}$-terminal flexível composto de 110 a 130 aminoácidos, essencial para a polimerização desta, conforme ilustrado na Figura 1. A porção CRD apresenta afinidade de ligação para $\beta$-galactosídeos presentes em glicoproteínas de sistemas biológicos, principalmente as da matriz extracelular. $\mathrm{Na}$ presença desses ligantes, a GAL-3 sofre mudanças conformacionais, formando uma estrutura (quaternária) em forma de pentâmero graças à porção flexível de sua cadeia (NEWLACZYL e YU, 2011). 


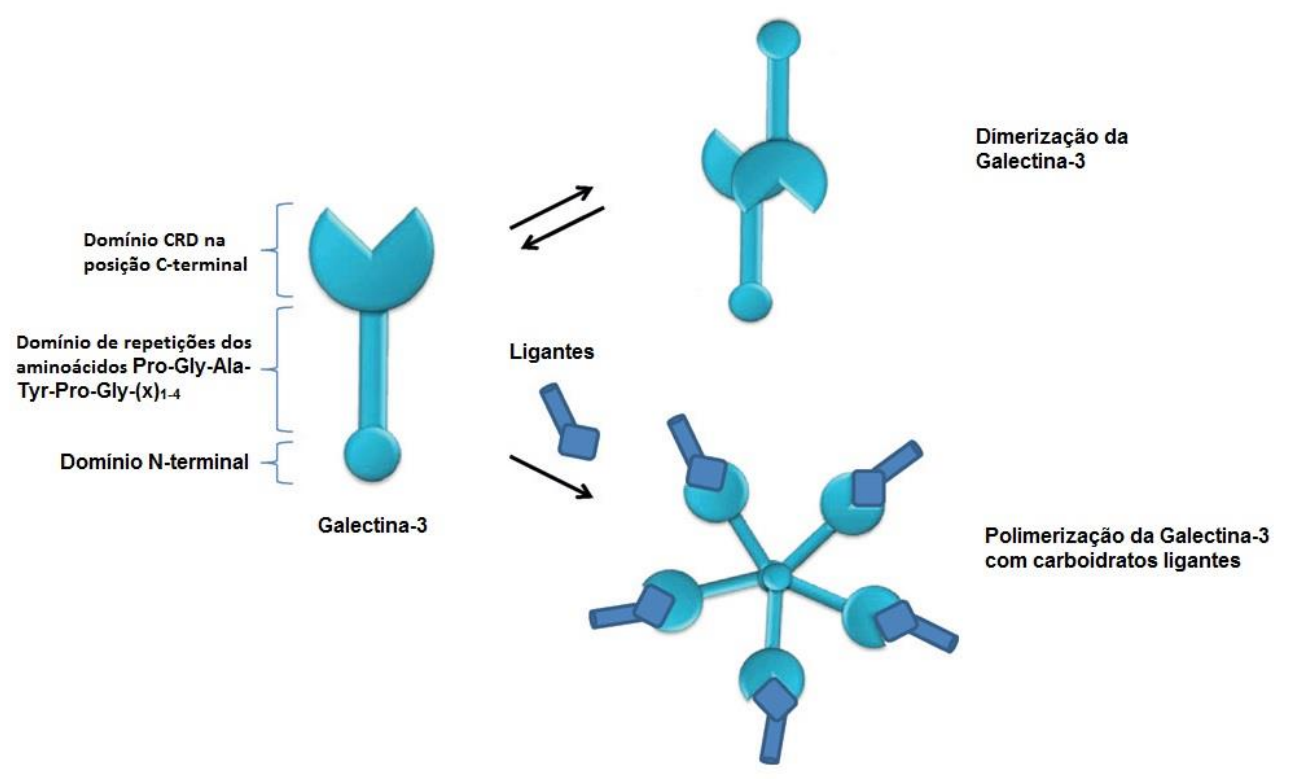

Figura 1. Representação esquemática da estrutura química da GAL-3. Figura adaptada de NEWLACZYL e YU (2011).

Experimentos demonstraram que ratos knockout para a expressão de GAL-3 não apresentaram alterações fenotípicas. Tal fenômeno pode indicar que sua função é substituível por outros membros da família das galectinas, e reafirma que sua superexpressão e mudança de localização são características peculiares para determinados tipos de câncer (NEWLACZYL e YU, 2011).

Sintetizada no citoplasma celular, a GAL-3 transita entre o citoplasma e núcleo, podendo também ser secretada para a superfície celular ou para o meio externo. No meio extracelular, a proteína encontra-se normalmente na forma dos pentâmeros acima exemplificados, sendo estruturas que interagem com os ligantes das superfícies celulares, formando estruturas entrelaçadas. Tal interação resulta na sinalização celular de moléculas que estão ligadas à superfície das células, permitindo então, a ocorrência de reações em cascata que, de forma geral, estimulam a sobrevivência celular. No ambiente extracelular, a proteína é responsável por promover migração celular, além de estimular angiogênese através de interação com o endotélio, bem como através da atração de macrófagos à região do tumor, que culmina em angiogênese induzida por macrófagos/monócitos (CARDOSO, 2016). A Figura 2 representa os efeitos desencadeados pela GAL-3.

Devido à sua capacidade de formar estruturas entrelaçadas, a GAL-3, quando superexpressa, pode reter sinalizadores pró-apoptóticos e bloquear a 
internalização de receptores promotores da morte celular, como o DR4 e DR5, impedindo a indução da apoptose por estas vias (MAZURECK et al. 2012).

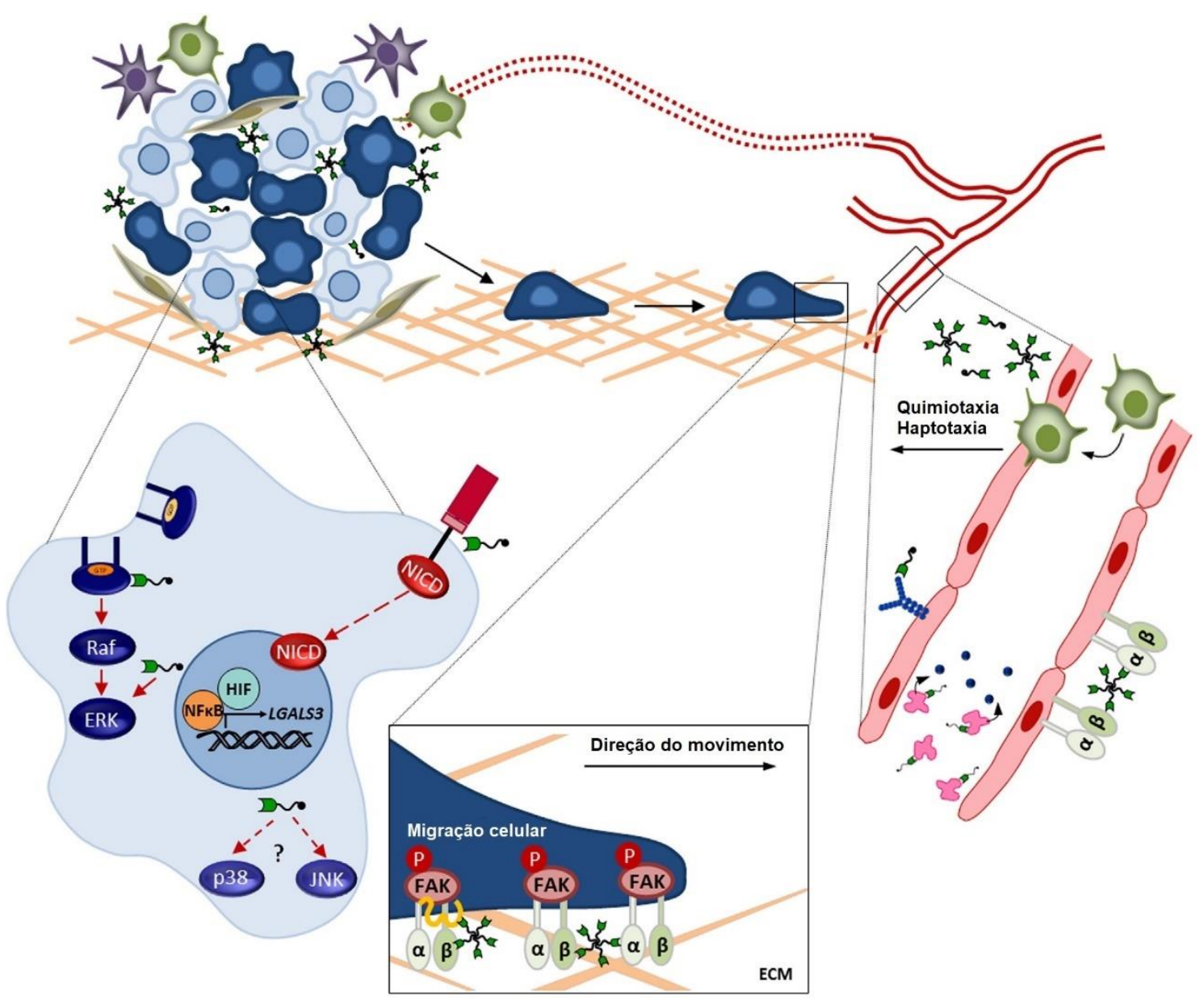

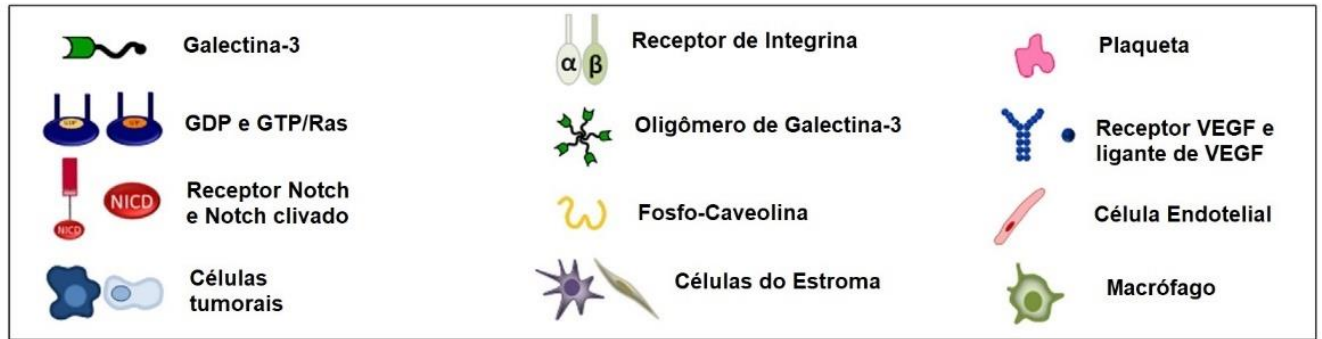

Figura 2. Representação esquemática dos efeitos promovidos pela Galectina-3. Raf: proteína quinase serina/treonina; ERK: quinase regulada por sinalização extracelular; HIF: fator induzido por hipóxia; NFkB: fator nuclear к B; LGALS3: gene codificador para a Galectina3; JNK: quinases N-terminal c-Jun; FAK: quinase de adesão focal; ECM: matriz extracelular. Figura adaptada de CARDOSO, 2016.

A GAL-3, além de interagir com resíduos de galactose presentes na membrana plasmática de diversas células, também consegue interagir com resíduos de galactose de polissacarídeos mais complexos. Um exemplo é a 
pectina de citros modificada térmica e/ou enzimaticamente, comercialmente conhecida como GCS-100 e que foi capaz de induzir a apoptose de células de mielomas e acumular as células nas fases $G_{1}$ e sub- $G_{1}$, diminuindo assim a proliferação celular e inibindo a metástase em modelos in vitro (STREETLY et al., 2010).

Nangia-Maker, et al. (2002) demonstraram que ratos alimentados com pectinas de citros modificadas apresentaram redução do volume de tumores mamários com relação ao grupo controle, além de demonstrarem queda acentuada da porcentagem de migração de células endoteliais da veia umbilical humana, cujo resultado foi proveniente da interação destas pectinas com a GAL3 , destacando a importância da interação entre estas duas moléculas.

Entretanto, ao compararem a eficácia de pectinas modificadas por tratamento térmico (HTCP - High Temperature Citrus Pectin) com as pectinas modificadas por tratamento de $\mathrm{pH}$, Hao et al. (2013) concluíram que as HTCP foram capazes de inibir a proliferação de diversos tipos de células cancerosas, induzir a apoptose celular pela via da Caspase-3, promover captura das células na fase $G_{2} / M$, inibir o crescimento de tumores $S-180$ em $49 \%$ com relação ao controle e estender o tempo de sobrevivência dos camundongos doentes utilizados no estudo, enquanto que a pectina modificada por $\mathrm{pH}$ não apresentou atividade antitumoral. Destaca-se deste estudo que os efeitos provocados pela HTCP nas células tumorais não possuem mecanismos imunomodulatórios envolvidos, tampouco se baseiam na inibição da GAL-3, permitindo inferir que sua ação possa se dar por efeito direto nas células tumorais. Jackson et al. (2007), por sua vez, fizeram uso de pectinas de citros com diversas modificações estruturais a fim de verificar os efeitos em linhagens de células de câncer prostático. Os autores concluíram que a atividade pró-apoptótica é favorecida pela presença de ramificações e ligações ésteres e que os efeitos observados não se deram por interação com a GAL-3, tido que os tipos celulares estudados não expressam esta proteína, indicando que outro mecanismo independente da inibição desta proteína possa estar associado à indução da morte celular pelas pectinas.

Ortega-González et al. (2014) demonstraram que oligossacarídeos nãodigeríveis foram capazes de produzir efeitos não-prebióticos em células do epitélio intestinal através de sinalização imunológica. O grupo observou que 
células cultivadas com polissacarídeos de diferentes origens foram capazes de induzir a produção de citocinas inflamatórias, como NF-kB, através de sinalização de receptores TLR4, proteínas classicamente associadas à indução de processos inflamatórios em células do sistema imunológico.

Atualmente, sabe-se que o receptor TLR4 também é expresso em enterócitos e, embora não seja explicada com precisão qual a função deste receptor nestas células do epitélio intestinal, reconhece-se a importância de sua ação na defesa do organismo através do reconhecimento e subsequente resposta a agentes patógenos. Cario et al. (2000) comprovaram a atividade imunológica do TLR4 em enterócitos quando estimulados pelo LPS de forma dose-dependente, embora sua ação seja bastante atenuada no ambiente intestinal. Isso se dá pelo fato destas células não expressarem o CD14 nativamente em sua membrana celular, utilizando-se da forma solúvel desta proteína presente no meio extracelular. Tal fenômeno explica a constante exposição do epitélio intestinal à microbiota da região sem desencadear respostas imunológicas agressivas constantemente.

Liu et al. (2010) ao investigarem a via de sinalização LPS/TLR4/NFkB, concluíram que um oligogalactano de maçã foi capaz de promover a internalização do TLR4 da membrana celular para o citoplasma, fazendo com que a resposta intestinal inflamatória de ratos à DMH/DSS (1,2-dimetil-hidrazina / Dextran Sulfato de Sódio - mistura de compostos capaz de provocar inflamação intestinal que rapidamente evolui para câncer colorretal) fosse otimizada, impedindo a instalação e progressão do câncer por vias relacionadas à resposta inflamatória, mostrando assim uma via independente da GAL-3 na progressão e/ou inibição do câncer de cólon. Neste mesmo estudo, culturas celulares de HT29 submetidas à tratamento com pectinas exibiram leve aumento da síntese de RNA mensageiro para TLR4, maior produção de TNFa e aumento da fosforilação de IkBa, o que resulta na otimização da resposta destas células epiteliais à estímulos inflamatórios decorrentes dos tratamentos com as pectinas.

Já Vogt et al. (2016) comprovaram a capacidade que as pectinas possuem de promover proteção do epitélio intestinal através da interação com o TLR4, ao avaliar a redução da resistência elétrica transepitelial de células expostas ao tratamento com PMA (phorbol 12-myristate 13-acetate). Os autores ainda associaram esta propriedade de defesa celular à esterificação das pectinas, 
concluindo que as pectinas com maior grau de esterificação resultaram em maior ativação do TLR4 epitelial.

Embora o receptor TLR4 esteja associado ao desencadeamento de respostas imunológicas, a sinalização resultante da estimulação desse receptor e/ou do receptor TLR3 também é capaz de promover a morte celular através do mecanismo de necroptose. A necroptose é uma via de morte celular programada, com características necróticas, que pode ser desencadeada quando ocorre evasão dos mecanismos apoptóticos normais (geralmente promovida por patógenos intracelulares), funcionando como uma via emergencial de garantir a eliminação do patógeno. Este mecanismo tem sido associado a condições inflamatórias como esclerose múltipla, esclerose lateral amiotrófica e doença de Crohn. Entretanto, não se sabe se estes são causas secundárias associadas à doença, ou se seriam fatores promotores destas, já que o processo de liberação de material intracelular provoca o desencadeamento de processos inflamatórios (NEWTON, 2016). A figura a seguir representa esquematicamente o processo de indução da necroptose por ativação de receptores TLR3/4.

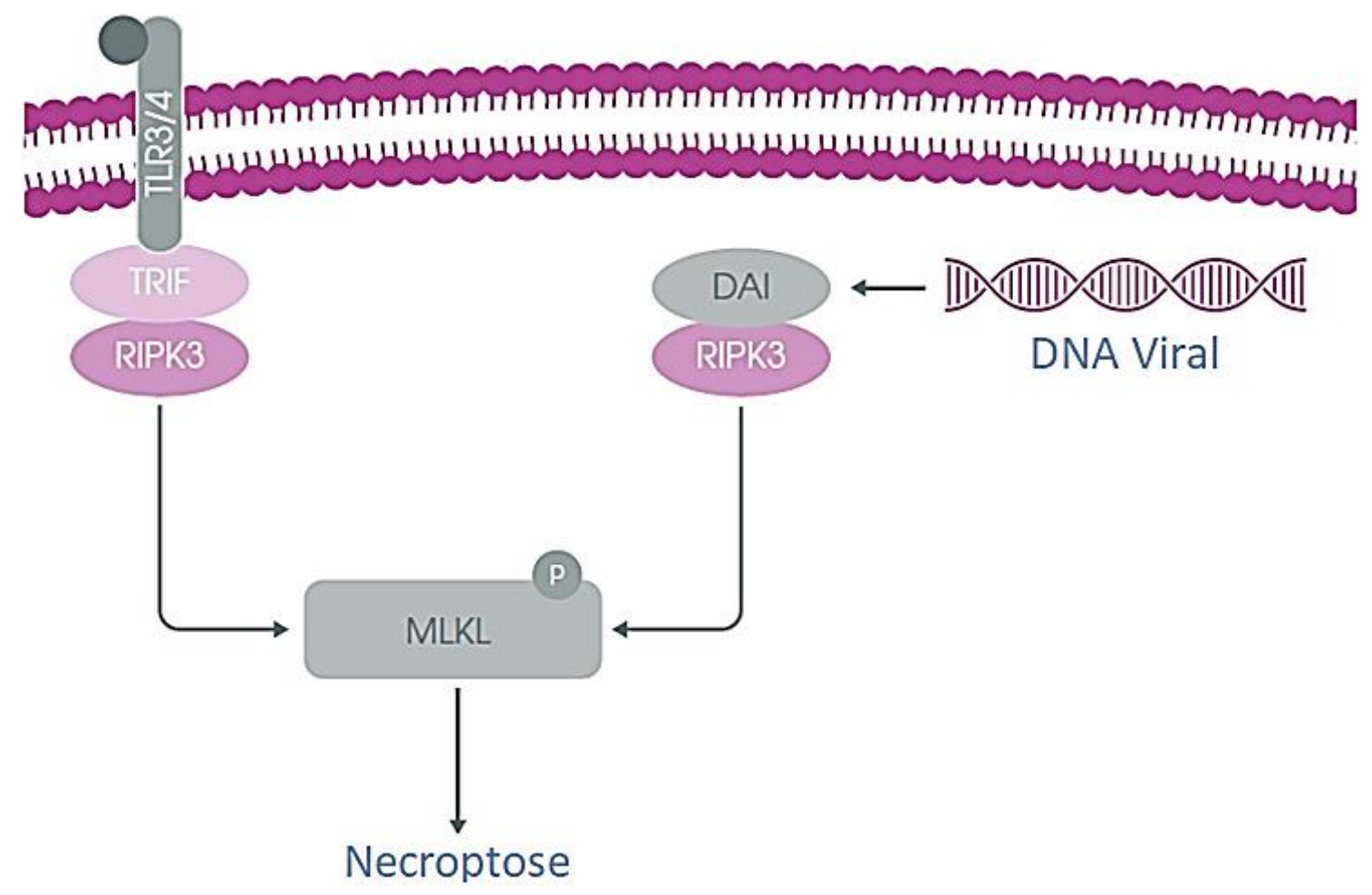

Figura 3. Representação esquemática da via necroptótica. TRIF: domínio TIR contendo interferon- $\beta$ indutor de adaptadores; RIPK3: proteína quinase serina/treonina 3 interagente com receptor; DAl: ativador dependente de DNA de fatores reguladores IFN; MLKL: domínio tipo quinase de linhagem mista; Figura adaptada de ABCAM. 
Prado, et al. (2017) verificaram que linhagens de câncer colorretal HCT116 e HT29 e de câncer de próstata PC3 submetidas a tratamentos com frações solúveis em água ricas em pectinas extraídas da polpa de mamões papaia com diferentes tempos de amadurecimento sofreram necroptose. Pectinas extraídas do fruto com 3 dias de amadurecimento pós-colheita promoveram elevação dos níveis de pAkt e pErk1/2 em HCT116, enquanto na HT29 promoveu efeito contrário, sugerindo que a linhagem HCT116 pode ter rapidamente acumulado espécies reativas de oxigênio, sugerindo possivelmente uma sinalização de receptores TLR visto que as pectinas testadas não inibiram a GAL-3 humana recombinante.

Ao avaliar a estrutura das pectinas, é possível inferir que os ramnogalacturonanos apresentam maior ação anti-proliferativa em células de câncer que os homogalacturonanos quando comparado à inibição da GAL-3. Já quando comparado à interação com o TLR4 e o possível desencadeamento de reações bioquímicas responsáveis pela morte celular, a porção de homogalacturonanos poderia interagir de maneira mais efetiva. Dados prévios do grupo de pesquisa mostram que as pectinas extraídas de diferentes amostragens de mamões podem ou não inibir a GAL-3, além de estimular vias de sinalização possivelmente envolvidas na estimulação do TLR4 de forma diferente aos resultados obtidos para as pectinas modificadas de citros. Isso pode ser devido ao fato de que nos mamões a modificação das pectinas se dá através do fenômeno de amadurecimento, aumentando a solubilidade destas em água e provavelmente favorecendo uma possível interação com a GAL-3 ou com - TLR4. Destaca-se que a fração solúvel em água das pectinas do mamão apresenta grau de esterificação de mais de 90\% (KOUBALA et al. 2014) e, conforme mencionado anteriormente, a ação das pectinas em receptores TLR4 é favorecida de forma proporcional ao grau de esterificação destas.

Devido a essas informações preliminares a eficácia das pectinas na promoção da apoptose e inibição da proliferação celular será estudada em duas culturas de células de câncer colorretal, a HCT116 e a HT29. A linhagem HCT116 é uma cultura indiferenciada de células tumorais, isolada a partir de um carcinoma (BRATTAIN, et al., 1981), apresenta alta capacidade invasiva (JUNIOR, et al. 2011) e possui mutação no gene KRAS (TABUSA, 2013). A 
linhagem HT29, por sua vez, provém de um adenocarcinoma (HEKMATI, 1990), apresenta diferenciação com mutação no gene BRAF e perfil menos agressivo (PRADO et al., 2017; CHRISTENSEN, 2012).

Ambas as células expressam a GAL-3 (PRADO et al., 2017), mas a HT29 apresenta o receptor TLR4 em quantidades significativamente maiores que a HCT116 (ZHAO et al. 2007; SUZUKI et al. 2003). Através da inibição química intercalada das moléculas alvo (GAL-3 e/ou TLR4), será possível compreender sob qual dessas vias as pectinas exercem sua função anti-proliferativa nas células de câncer epitelial de cólon. Além disso, a inibição biológica da expressão da GAL-3 e TLR4 com uso do método CRISPR (Clustered Regularly Interspaced Short Palindromic Regions), permitirá complementar as informações obtidas pelas inibições químicas e assim propor um panorama bioquímico da ação das pectinas de frutas nas células de câncer.

A ferramenta CRISPR-Cas9 foi desenvolvida a partir da descoberta de que bactérias e arqueas apresentavam sistema de imunidade adaptativa contra fagos e plasmídeos, através do reconhecimento de padrões adjacentes de protoespaçados (PAMs - Protospacer Adjacent Motifs) presentes no material genético do organismo invasor. A partir do reconhecimento desses padrões, o microorganismo afetado é capaz de produzir fitas de RNAs complementares, chamadas crRNA (CRISPR RNA), que formam complexos ribonucleoproteicos com endonucleases específicas, denominadas Cas (CRISPR Associated protein). A partir da formação deste complexo, a bactéria é capaz de reconhecer o material genético invasor na ocorrência de nova infecção, e promover a quebra das ligações fosfodiésteres da molécula alvo. Como o reparo de material genético em biossistemas, nessas situações, é suscetível a erros, geralmente o material genético invasor é destruído através do mecanismo de junção não homóloga das extremidades da fita de DNA (AMITAI e SOREK, 2016). Desta forma, sabendo-se que o complexo ribonucleoproteico formado possui uma região de RNA editável, é possível desenvolver uma molécula chamada gRNA (guide RNA) que seja complementar a um determinado gene de interesse.

O gRNA produzido com base em determinado gene de interesse permite então que a ribonucleoproteína desenvolvida seja capaz de reconhecer este gene e promover a quebra da dupla-fita de DNA, para fins de inativação do gene. Além disso, é possível inserir sequências de DNA que, através de mecanismos 
de reparo dirigido por homologia (HDR - Homology Directed Repair) podem promover o reparo definitivo de genes relacionados com doenças genéticas, por exemplo. Por ser altamente específico, ter custo relativamente baixo e por produzir mutações permanentes, a ferramenta rapidamente tornou-se de grande importância para a engenharia genética pois, além de promover a deleção de genes de interesse, a ribonucleoproteína, cuja função de endonuclease pode ser inativada, pode também ser acoplada a diversas proteínas, permitindo o estudos de mapeamento genômico através da acoplagem de GFPs (Green Fluorescent Protein) à Cas9 permitindo ainda a regulação transcricional através da acoplagem de ativadores ou repressores transcricionais à ribonucleoproteína (TYCKO, et al. 2017).

Sendo assim, o presente trabalho utilizou dessa tecnologia na tentativa de promover o silenciamento dos genes da galectina-3 e do TLR4, buscando explorar alguns dos possíveis mecanismos pelos quais as pectinas de mamões são capazes de comprometer a capacidade e eficiência metabólica de células de CRC, com possíveis benefícios para a saúde.

\section{Objetivos}

O principal objetivo do trabalho foi elencar os impactos no metabolismo geral de células de câncer colorretal promovidos pela ação de frações solúveis em água de mamão papaia ricas em pectinas somados às inibições químicas da Galectina-3 e dos receptores TLR4, assim como a inibição biológica da Galectina-3 gerada pela técnica de CRISPR-Cas9.

Este estudo buscou, em conjunto com os demais trabalhos realizados pela equipe de pesquisadores sob orientação do prof. Dr. João Paulo Fabi, delinear os efeitos benéficos produzidos no organismo humano provenientes do consumo de pectinas de mamões amadurecidos naturalmente.

\section{Material e métodos}

\subsection{Amostras de mamão papaia}

As amostras de frutos utilizadas nos experimentos foram as mesmas estudadas em FABI, et al. (2014) e obtidas a partir de um produtor situado na cidade de Linhares, Espírito Santo, Brasil, tendo sido colhidos com até $25 \%$ da 
casca amarelada, correspondendo a aproximadamente 150 dias pós-antese. No artigo referenciado, apenas os primeiros quatro dias após a colheita foram estudados. No presente trabalho, a amostra utilizada corresponde ao fruto congelado com 6 dias de amadurecimento após a colheita.

\subsection{Extração e purificação das pectinas do material celular de mamões maduros}

Amostras da polpa de mamões maduros congeladas em $\mathrm{N}_{2}$ líquido (aproximadamente 20,00 gramas) foram trituradas e incubadas em triplicata em mistura de clorofórmio e metanol $(1: 1, \mathrm{v} / \mathrm{v})$ a $60^{\circ} \mathrm{C}$ por 20 minutos, para remoção de pigmentos e gorduras, além de promover inativação enzimática (CARRINGTON et al. 1993; IRWIN et al. 2003). Em seguida, as amostras foram centrifugadas por 15 minutos a $10000 \mathrm{Xg}$ e os sobrenadantes foram descartados. Os materiais precipitados foram lavados com 3 volumes de etanol $80 \%$ para retirada de açúcares solúveis e com 3 volumes de acetona para fins de secagem e retirada de impurezas remanescentes. Após secagem em temperatura ambiente, os resíduos foram pesados a fim de determinar a constituição da massa total de parede celular extraída e cálculo dos rendimentos. Finalizadas as pesagens, as amostras foram extraídas por 3 vezes com $20 \mathrm{~mL}$ de água destilada sob agitação constante por 20 minutos e centrifugadas (10000 Xg) por 10 minutos. Os sobrenadantes foram liofilizados, pesados e denominados como fração solúvel em água (FSA).

\subsection{Ensaios de caracterização da pectina de mamão papaia}

\subsubsection{Composição em monossacarídeos da pectina do mamão}

A determinação da composição de açúcares neutros e ácidos urônicos das amostras em triplicata de pectina extraídas foi realizada através da hidrólise de 1,0 mg da FSA (extraída conforme descrito em 3.2) em 1,0 mL de Ácido Trifluoracético (TFA) 2,0 M a 120ํ por 90 minutos. Após hidrólise, foram adicionados 2,0 $\mathrm{mL}$ de álcool t-butílico às replicatas da amostra, e posteriormente submetidas à secagem em fluxo de $\mathrm{N}_{2}$ até atingir $\mathrm{pH}$ em torno de 6,0. Em seguida, as replicatas foram ressuspendidas em $\mathrm{H}_{2} \mathrm{O}$ MilliQ e filtradas em filtro millipore de $0,45 \mu \mathrm{m}$ de porosidade e analisados em sistema HPAECPAD ICS 5000+, em coluna analítica CarboPac PA10 (250 x $4 \mathrm{~mm})$, com 
respectiva pré-coluna. Os padrões utilizados para os açúcares neutros foram fucose, arabinose, ramnose, galactose, glicose, xilose e manose; e para os ácidos urônicos foram os ácidos galacturônico e glicurônico.

\subsubsection{Determinação da homogeneidade e peso molecular de polissacarídeos da FSA de pectina do mamão papaia}

Para avaliação da homogeneidade e determinação do peso molecular dos polissacarídeos presentes na FSA da pectina extraída do mamão papaia, amostras em triplicata foram diluídas em água $(0,5 \mathrm{mg} / \mathrm{mL})$ e filtradas em filtro millipore com porosidade de $0,45 \mu \mathrm{m}$. A análise foi realizada em sistema cromatográfico de exclusão por tamanho, acoplado com detectores por índice de refração e de comprimento de onda múltiplo (HPSEC-RID/MWD), em sistema Infinity (Agilent, Santa Clara, CA, EUA). O sistema dispunha de quatro colunas PL-aquagel-OH (30, 40, 50 e 60; $300 \times 7,5 \mathrm{~mm}$, porosidade $8,0 \mu \mathrm{m}$ ) conectadas em série. A fase móvel utilizada foi composta de solução de nitrito de sódio 0,05 M com azida sódica $(0,2 \%)$, em fluxo constante de 0,6 $\mathrm{mL} / \mathrm{min}$. Como padrões, utilizou-se a série Dextran-T de Leuconostoc mesenteroides (Sigma-Aldrich, EUA) com tamanhos de 5, 12, 25, 50, 80, 150, 410 e $750 \mathrm{kDa}$, bem como solução de glicose 1,0\% para indicação do volume de permeação total (volume de eluição total). Após obtenção do cromatograma, os pesos moleculares médios das amostras são definidos através da correlação entre o LogMW vs Tr dos padrões utilizados. Através da regressão linear obtida desta correlação, é possível inferir os valores de pesos moleculares médios das amostras.

\subsubsection{Determinação do teor de proteínas pelo método de Bradford}

O teor de proteínas das amostras de pectinas obtidas foi determinado baseando-se no método de Bradford (1976), adaptado para leitura em placa de 96 poços. Replicatas técnicas de 1,0 mg de pectina foram diluídas em água e distribuídas em poços contendo corante diluído para ensaio de proteínas $(1,0 \mathrm{~mL}$ Bio-Rad Protein Assay Dye Reagent Concentrate $+3,0 \mathrm{~mL} \mathrm{H}_{2} \mathrm{O}$ MilliQ) e analisadas em espectrofotômetro (leitura em $\lambda=595 \mathrm{~nm}$ ). $O$ branco analítico foi preparado a partir da mistura de $\mathrm{H}_{2} \mathrm{O} \mathrm{MilliQ}$ + solução corante. A curva-padrão 
utilizada foi construída utilizando 10 concentrações graduais $(1,0-10,0 \mu \mathrm{g} / \mu \mathrm{L})$ de Albumina Sérica Bovina + solução corante em qsp. $200 \mu \mathrm{L}$ por poço.

\subsubsection{Determinação da concentração de compostos fenólicos totais pelo método de Folin-Ciocalteau}

A presença de compostos fenólicos na amostra foi determinada utilizandose método descrito por Swain e Hillis (1959), adaptado para leitura em placa de 96 poços. A curva-padrão foi preparada utilizando-se ácido gálico em 10 concentrações graduais $(0,1-1,0 \mu \mathrm{g} / \mu \mathrm{L})$, completando cada poço com $\mathrm{H}_{2} \mathrm{O}$ MilliQ para 12,5 $\mu \mathrm{L}$. Em seguida, foram adicionados $12,5 \mu \mathrm{L}$ de Solução Reagente de Folin, 200,0 $\mu \mathrm{L}$ de $\mathrm{H}_{2} \mathrm{O}$ MilliQ e $25 \mu \mathrm{L}$ de solução supersaturada de $\mathrm{Na}_{2} \mathrm{CO}_{3}(0,5 \mathrm{~g} / \mathrm{mL}$ de $\mathrm{H} 2 \mathrm{O}$ MilliQ). As amostras foram preparadas utilizando o mesmo procedimento utilizado na construção da curva-padrão, substituindo as diluições de ácido gálico por $12,5 \mu \mathrm{L}$ de solução $2,0 \mathrm{mg} / \mathrm{mL}$ de pectina (FSA). Para o branco de leitura, utilizou-se $12,5 \mu \mathrm{L}$ de $\mathrm{H}_{2} \mathrm{O}$ MilliQ em substituição à amostra e ao ácido gálico, seguindo mesmo método de preparo descrito anteriormente. Após as preparações, a placa foi mantida em repouso por 30 minutos, sob abrigo de luz. Após o tempo de descanso, foi realizada leitura em espectrofotômetro sob $\lambda=720 \mathrm{~nm}$. Os resultados obtidos foram expressos em miligramas de equivalente de Ácido Gálico (EqAG).

\subsection{Ensaios biológicos}

\subsubsection{Cultivo celular e contagem de células viáveis}

As linhagens de células de câncer colorretal provenientes da American Type Culture Collection (ATCC; Manassas, VA, EUA) HT29 (ATCC: HTB-38) e HCT116 (no ATCC: CCL 247) utilizadas foram cultivadas de acordo com as diretrizes da ATCC para manutenção celular e instruções descritas em PERES (2005). As linhagens foram cultivadas em meio DMEM suplementado com $10 \%$ Soro Bovino Fetal (FBS) e incubadas em atmosfera umidificada, a $37^{\circ} \mathrm{C}$ e $5 \%$ $\mathrm{CO}_{2}$. Ambas as linhagens celulares foram adquiridas do Banco de Células do Rio de Janeiro. A viabilidade celular foi contabilizada através em contador de células automatizado Bio-Rad TC20 Automated Cell Counter após tratamento com Azul de Tripano (1:1 v/v). 


\subsubsection{Inibições químicas in vitro da GAL-3 e do TLR4}

Para a realização dos ensaios de inibições químicas das referidas proteínas, replicatas técnicas e biológicas das linhagens celulares foram distribuídas em placas de 96 poços, de forma a se obter a concentração de $1 \mathrm{x}$ $10^{4}$ células/poço. Os poços foram preparados com $180 \mu \mathrm{L}$ de cada cultura celular e, após tempo necessário para total adesão das células à placa (12h), houve adição posterior de $20 \mu \mathrm{L}$ de solução contendo a substância a ser analisada, de forma a obter um volume final de $200 \mu \mathrm{L} /$ poço. Para cada linhagem celular, foram realizados cinco tipos de tratamentos distintos, cada um com duração de 24, 48 e 72 horas, detalhadamente descritos a seguir.

Como controle positivo de morte celular, as replicatas foram submetidas a tratamento com Triton- $X 0,2 \%$ e, concomitantemente, células foram cultivadas em meio de cultura sem tratamentos a fim de estabelecer o branco experimental (controle positivo de crescimento celular). A viabilidade celular foi determinada através do ensaio colorimétrico de redução do MTT (descrito em 3.3.9).

\subsubsection{Tratamento 0 : Inibidores químicos}

A fim de averiguar se os inibidores químicos específicos utilizados ( $\mathrm{N}$ Acetil-Lactosamina para GAL-3 e Resatorvid para TLR4) seriam capazes de produzir alterações na viabilidade celular das linhagens HCT116 e HT29, três diferentes passagens das células foram distribuídas em triplicatas técnicas em placa de 96 poços e submetidas a 4 concentrações diferentes de cada inibidor, preparadas em meio DMEM 10\% FBS. As concentrações utilizadas para os inibidores foram definidas de acordo com MORRIS et al. (2004) e MATSUNAGA et al. (2011). Os poços contendo branco experimental (sem tratamento) foram preparados nas placas correspondentes a este tratamento, bem como os controles positivos para morte celular (tratamento com Triton-X 100). Experimentos prévios realizados por outros integrantes do grupo de estudo, demonstraram que a suplementação dos inibidores ao longo das 24 horas para os tempos de 48 e 72 horas de tratamento não alterou os resultados.

\subsubsection{Tratamento 1: FSA da pectina de mamão}

De modo semelhante ao explicado no item 3.4.2.1, replicatas biológicas e técnicas das linhagens utilizadas no estudo foram submetidas a tratamento, após 
tempo necessário para adesão em placa, com 4 soluções da FSA extraída conforme descrito em 3.2, em diferentes concentrações $(0,2 \% ; 0,05 \% ; 0,03 \%$ e $0,01 \% \mathrm{p} / \mathrm{v})$ a fim de constatar os efeitos provocados pela exposição das células às pectinas do mamão papaia.

\subsubsection{Tratamento 2: N-Acetil-Lactosamina + FSA}

As células foram submetidas inicialmente a tratamento com solução 1,0 $\mu \mathrm{M}$ de N-Acetil-Lactosamina em meio DMEM 10\% FBS e, após 15 minutos de exposição, foram tratadas com 4 soluções de FSA em concentrações diferentes, em triplicata, conforme descrito em 3.4.2.2. A solução estoque de N-AcetilLactosamina foi preparada através da diluição do composto em $\mathrm{H}_{2} \mathrm{O}$ MilliQ, onde a partir desta, foi aliquotado volume necessário para preparo da solução descrita anteriormente em meio DMEM.

\subsubsection{Tratamento 3: Resatorvid + FSA}

Assim como descrito em 3.4.2.3, as células foram submetidas a tratamento com solução de 1,0 $\mu \mathrm{M}$ de Resatorvid em meio DMEM 10\% FBS e, após 15 minutos de exposição, foram tratadas com as 4 soluções de FSA referidas anteriormente, em triplicata. A solução estoque de Resatorvid foi preparada através da diluição do composto em Dimetilformamida (MATSUNAGA et al., 2011), onde a partir desta, foi aliquotado volume necessário para preparo da solução descrita anteriormente em meio DMEM.

\subsubsection{Tratamento 4: N-Acetil-Lactosamina + Resatorvid + FSA}

Conforme metodologia utilizada nos outros tratamentos, fora preparada uma solução contendo 1,0 $\mu \mathrm{M}$ de N-Acetil-Lactosamina + 1,0 $\mu \mathrm{M}$ de Resatorvid em meio DMEM 10\% FBS e aplicada às células aderidas em placa. Após 15 minutos, foram adicionadas as 4 soluções de FSA referidas anteriormente no item 3.4.2.2.

\subsubsection{Ensaio colorimétrico de viabilidade celular (redução do MTT)}

A viabilidade celular de ambas as linhagens estudadas foi medida através da redução do composto MTT (brometo de 3-(4,5-dimetiltiazol-2-il)-2,5- 
difeniltetrazólio) pelas desidrogenases mitocondriais de células vivas, após os tratamentos de inibições químicas serem concluídos.

Após os tempos de tratamento decorridos, o meio de cultura de cada poço foi removido, com subsequente adição de $180 \mu \mathrm{L}$ de novo meio DMEM $10 \%$ FBS. Em seguida, foram adicionados $20 \mu \mathrm{L}$ de solução $5,0 \mathrm{mg} / \mathrm{mL}$ de MTT (coloração amarelada) em cada poço. Após 3 horas de incubação em atmosfera umidificada, a $37^{\circ} \mathrm{C}$ e $5 \% \mathrm{CO}_{2}$, o meio de cultura $+\mathrm{MTT}$ foi removido de cada poço, com subsequente adição de $150 \mu \mathrm{L}$ de Dimetil Sulfóxido (DMSO) para promover lise celular e, consequentemente, diluir o composto MTT reduzido (cor roxa). As placas foram então submetidas a agitação constante por 3 minutos e, em seguida, foram analisadas em espectrofotômetro, em $\lambda=490 \mathrm{~nm}$. O branco experimental (células sem tratamentos) foi utilizado como parâmetro de crescimento celular de $100 \%$, e os outros grupos foram comparados a ele para obtenção da porcentagem de viabilidade celular.

\subsubsection{Curva padrão de crescimento populacional}

Considerando que o ensaio de viabilidade celular por redução do MTT reflete a condição metabólica das populações celulares avaliadas, in vitro, seus valores não são capazes de refletir, direta e numericamente, a população celular avaliada, embora seja um teste de grande valia para avaliar o comportamento metabólico das linhagens celulares frente aos tratamentos utilizados. Para tal, é necessária a realização de uma curva padrão de crescimento, a fim de fornecer uma regressão linear capaz de correlacionar os valores de absorbância obtidos de acordo com a redução do MTT com as populações celulares, permitindo converter os valores obtidos nos testes descritos ao longo do item 3.4 .3 e $4.6 \mathrm{em}$ valores de crescimento ou queda populacional.

A curva padrão de crescimento foi obtida através da distribuição de valores crescentes de células em placa de 96 poços, obtendo um total de 6 pontos, sendo estes $1,00 \times 10^{3} ; 5,00 \times 10^{3} ; 1,00 \times 10^{4} ; 3,00 \times 10^{4} ; 5,00 \times 10^{4} \mathrm{e}$ $1,00 \times 10^{5}$. Após distribuição das populações celulares em seus respectivos poços com $180 \mu \mathrm{L}$ de meio de cultura (DMEM, suplementado com 10\% FBS + $1 \%$ Streptomicina e Ampicilina), foi adicionado $20 \mu \mathrm{L}$ de solução de MTT 5,0 
$\mathrm{mg} / \mathrm{mL}$ em cada poço, e as placas foram incubadas por 3 horas, em incubadora a $37^{\circ} \mathrm{C}$, com atmosfera de $5 \% \mathrm{CO}_{2}$. Após tempo de incubação, as placas foram submetidas a processo de centrifugação por 2 minutos, a $960 \mathrm{rpm}$. Em seguida, o sobrenadante foi descartado, e o precipitado solubilizado em $150 \mu \mathrm{L}$ de DMSO, a fim de promover lise celular e solubilização dos cristais reduzidos de MTT (coloração roxa). As placas foram então submetidas a agitação constante por 3 minutos e, em seguida, foram analisadas em espectrofotômetro, em $\lambda=490 \mathrm{~nm}$.

\subsubsection{Knock-out da expressão de TLR4 e Galectina-3 das linhagens HCT116 e HT29 através da técnica CRISPR-Cas9}

O knock-out da expressão das proteínas TLR4 e Galectina-3 nas linhagens celulares HCT116 e HT29 foi realizado com a utilização da técnica CRISPRCas9. Os desligamentos foram realizados isoladamente para cada proteína.

Para tal, as linhagens foram semeadas em placas de cultura de 6 poços $\left(1,5 \times 10^{5}-2,5 \times 10^{5}\right.$ células em $3 \mathrm{~mL}$ de meio de cultura DMEM) 24 horas antes do procedimento de transfecção.

Em seguida, foram preparadas as soluções contendo o DNA plasmidial correspondente à proteína de interesse (Solução $A: 1,0 \mu \mathrm{g} T L R 4$ ou galectin-3 CRISPR/Cas9 KO Plasmid + 1,0 $\mu \mathrm{g}$ TLR4 ou galectin-3 Double Nickase Plasmid + 1,0 $\mathrm{gg}$ TLR4 ou galectin-3 HDR Plasmid em Plasmid Transfection Medium qsp.150,0 $\mathrm{LL}$ ), e outra solução contendo reagente de transfecção (Solução B: 5,0 - 10,0 $\mu \mathrm{L}$ Ultracruz Transfection Reagent em Plasmid Transfection Medium qsp. $150 \mu \mathrm{L}$ ). Cada solução foi preparada em temperatura ambiente e permaneceu em repouso por 5 minutos.

Após o tempo de repouso, as soluções A e B foram misturadas, imediatamente agitadas e incubadas em temperatura ambiente por 20 minutos, de forma a serem adicionadas aos poços contendo as culturas celulares.

Após transfecção, as células foram mantidas sob incubação em incubadora a $37^{\circ} \mathrm{C}$, sob atmosfera de $5,0 \%$ de $\mathrm{CO}_{2}$ por $72 \mathrm{~h}$, sem troca de meio de cultura. Em seguida, as células foram selecionadas em meio de cultura DMEM, suplementado com $10 \%$ FBS e Puromicina $(1,0 \mu \mathrm{g} / \mathrm{mL})$, a fim de selecionar os clones mutantes. 
Ao fim do procedimento de mutação e seleção dos clones estáveis, as culturas celulares foram analisadas em microscópio ótico de fluorescência, a fim de detectar a emissão de fluorescência proveniente da expressão de GFP e RFP (Green Fluorescent Protein e Red Fluorescent Protein, respectivamente). O gene para a expressão dessas proteínas estava contido em cada um dos plasmídeos utilizados na transformação, conforme descrito anteriormente (CRISPR/Cas9 KO Plasmid e Double Nickase Plasmid continham os genes para a expressão de GFP, enquanto o HDR Plasmid continha o gene para a expressão de RFP), e sua visualização em microscopia ótica de fluorescência é um indicativo de que a incorporação dos plasmídeos e assimilação da informação genética ali contida pelas células foi bem-sucedida.

\subsubsection{Isolamento de linhagens fluorescentes por citometria de fluxo (FACS Cell Sorting)}

Após transfecção dos plasmídeos e suposta modificação gênica das células pelo método descrito em 3.4.5., e subsequente constatação de fluorescência oriunda da expressão de GFP e RFP em microscopia ótica de fluorescência, as linhagens que apresentaram melhores sinais de adaptação ao procedimento (velocidade de crescimento, contagem celular de viabilidade e pontos de fluorescência em placa), foram submetidas à técnica de citometria de fluxo ativada por fluorescência (FACS), a fim de isolar as células que potencialmente tenham sofrido o desligamento gênico, com o intuito de otimizar o método de modificação gênica.

A citometria de fluxo foi realizada utilizando-se as instalações do Departamento de Imunologia do Instituto de Ciências Biomédicas da USP, por intermédio do Centro de Facilidades de Apoio à Pesquisa (CEFAP).

\subsubsection{Western Blotting}

A técnica de Western Blotting foi empregada para confirmar o desligamento da expressão gênica das proteínas TLR4 e Galectina-3 na linhagem HCT116, promovido através da técnica CRISPR-Cas9.

A linhagem HT29 não foi capaz de resistir à modificação gênica induzida pelo sistema CRISPR-Cas9 utilizado neste trabalho, deixando, portanto, de ser utilizada para os demais experimentos conduzidos. 
As culturas celulares submetidas ao processo de desligamento gênico e selecionadas de acordo com o descrito no item 3.4.5. foram submetidas à lise celular em tampão RIPA contendo coquetel inibidor de protease (protease inhibitor cocktail - Sigma - p8340), sob agitação por 15 minutos, a $4^{\circ} \mathrm{C}$. Após lise, as células foram coletadas com o auxílio de espátula adequada, e centrifugadas a $10.000 \mathrm{Xg}$, por 10 minutos, a $4^{\circ} \mathrm{C}$. Ao fim do processo, 0 sobrenadante foi coletado e armazenado em congelador a $-20^{\circ} \mathrm{C}$.

Após lise celular e coleta do material proteico resultante, a quantidade total de proteínas foi determinada através do ensaio BCA (Bicinchonic Acid - Pierce ${ }^{\mathrm{TM}}$ BCA Protein Assay Kit - Thermo Fisher) com leitura das amostras em espectrofotômetro $(\lambda=562 \mathrm{~nm})$.

As amostras dos lisados obtidos a partir das culturas celulares HCT116 foram submetidas ao processo de separação por eletroforese em géis de poliacrilamida (SDS-PAGE) de gradiente 4 - 20\% (Bio-rad), sob corrente constante de $140 \mathrm{~V}$ até o fim da corrida, indicado pela chegada da banda do corante de Laemmli adicionado à amostra, no fim da placa contendo o gel. Os poços dos géis foram ocupados com $5 \mu \mathrm{L}$ de padrões de pesos moleculares (GE Healthcare Amersham ECL Plex Fluorescent Rainbow Markers); $20 \mu \mathrm{g}, 10 \mu \mathrm{g}$ e $5 \mu \mathrm{g}$ de proteínas totais obtidas dos lisados de células HCT 116 nativas; e $20 \mu \mathrm{g}$ de amostras de culturas HCT116 tratadas com os plasmídeos, separadas por procedimento FACS (descrito em 3.4.6.), divididas entre os clones que foram selecionadas pela expressão de RFP, e clones recuperados após cell sorting (portanto, contendo RFP e traços de GFP). Para as amostras de lisado celular HCT116 TLR4 KO, foram adotados como controle, as mesmas quantidades em massa de proteínas totais e volumes de lisado de HCT116 nativa que as utilizadas para o teste de HCT116 GAL-3 KO; com os poços correspondentes às amostras de HCT116 TLR KO contendo $20 \mu \mathrm{g}$ de proteínas totais, em duplicata.

Após separação, os géis de poliacrilamida contendo as amostras foram submetidos a processo de transferência semi-dry, a fim de fixar as proteínas de interesse em membrana de nitrocelulose, para posterior revelação. O processo de transferência foi realizado em equipamento Trans-Blot Turbo Transfer System (Bio-Rad), de forma que as amostras foram submetidas a $25 \mathrm{~V}$ e $1.0 \mathrm{~A}$ constantemente, por 45 minutos. Ao fim do procedimento, as membranas contendo as amostras foram imersas em soluções de anticorpos primários 
específicos para cada uma das proteínas de interesse, e sequencialmente submetidas a tratamento com anticorpos secundários, acoplados à enzima HRP, permitindo a revelação da membrana por imunofluorescência. A proteína utilizada como referência para o teste foi a $\beta$-Actina, devido ao seu peso molecular (43 kDa).

Após tempo de incubação com os devidos anticorpos, as membranas foram submetidas a tratamento com o kit Clarity Max Western ECL Substrate, de acordo com as instruções fornecidas pelo fabricante, e então reveladas. A ausência de fluorescência na região de banda correspondente à proteína de interesse, em comparação com amostra de cultura celular não submetida ao desligamento gênico, confirma a ação do sistema CRISPR-Cas9.

\subsubsection{Tratamentos da linhagem HCT116 KO para expressão de GAL-3 com diferentes pectinas de mamão}

Após modificação gênica, isolamento e confirmação do $\mathrm{KO}$ para a expressão de GAL-3 em linhagem HCT116, conforme descrito em 3.4.5., 3.4.6. e 3.4.7., passagens da referida linhagem foram submetidas a tratamentos com diferentes frações de pectinas de mamão papaia, com subsequente determinação do estado metabólico através do ensaio de redução do MTT, conforme descrito em 3.4.3. Os ensaios foram conduzidos considerando tempos de 24,48 e $72 \mathrm{~h}$, e $\mathrm{n}=4$ para cada passagem, com populações celulares de $10^{4}$ células/poço.

As amostras de fibras utilizadas para este ensaio com suas concentrações designadas foram cedidas por outros alunos do departamento para os testes, e são denominadas a seguir:

- MCP: Modified Citrus Pectin $[1,0 \%$ e 0,1\% p/V] - Pectinas de Citrus Modificadas, através de tratamentos com altas temperaturas e/ou pH. Tratam-se de oligossacarídeos extensivamente conhecidos em literatura por sua atividade antitumoral (GLINSKY e RAZ, 2009; PRADO et al., 2019a; LECLERE, et al. 2013). As diferentes concentrações foram aplicadas às culturas isoladamente, e em concomitância com o inibidor de receptores TLR4 Resatorvid [1,0 $\mu \mathrm{M}]$. 
A amostra utilizada foi caracterizada em PRADO et al, 2019b, possuindo 35,2 kDa de peso molecular média.

- 4FA: Fração ácida das pectinas de mamões com maturação de 4 dias pós-colheita $[0,1 \% \mathrm{p} / \mathrm{V}]$, aplicada às culturas isoladamente. A amostra foi caracterizada por Lucas de Freitas Pedrosa, e é composta por uma fração péctica de $133 \mathrm{kDa}$ de peso molecular média (dados não publicados).

- 4FSA e 5FSA: Frações solúveis em água das pectinas de mamões com maturação de 4 e 5 dias pós-colheita, respectivamente $[0,1 \% \mathrm{p} / \mathrm{V}]$, aplicadas às culturas isoladamente e em concomitância com o inibidor de receptores TLR4 Resatorvid $[1,0 \mu \mathrm{M}]$. As amostras foram caracterizadas em PRADO, et al. 2016, cujos pesos moleculares correspondem a 71 e $73 \mathrm{kDa}$.

- 3FSO: Fração solúvel em oxalatos das pectinas de mamões com maturação de 3 dias pós-colheita $[0,1 \% \mathrm{p} / \mathrm{V}]$, aplicadas às culturas isoladamente e em concomitância com o inibidor de receptores TLR4 Resatorvid [1,0 $\mu \mathrm{M}]$. A amostra foi caracterizada em PRADO, et al. 2019c, apresentando peso molecular médio entre 410 e 80 kDa.

- 6DPC: Anteriormente identificada apenas como 'FSA' para os ensaios de inibição química. Trata-se da fração solúvel em água das pectinas de mamões com maturação de 6 dias pós-colheita $[0,2$ e 0,1\% p/ $\mathrm{V}]$, aplicadas às culturas isoladamente em concomitância com o inibidor de receptores TLR4 Resatorvid [1,0 $\mu \mathrm{M}]$. A amostra foi caracterizada neste trabalho, conforme descrito no item 3.3.

Neste contexto, faz necessário destacar que todas as amostras utilizadas foram capazes de promover inibição da GAL-3, exceto a do atual trabalho, 6DPC (dado não exposto), sendo de grande valia para este trabalho, especialmente considerando que foram obtidas de pontos de maturação e formas de extração diferentes, conforme abordado na descrição de cada uma delas.

\subsection{Análise estatística dos resultados}

Os resultados foram expressos como média \pm desvio padrão (DP) para gráficos em barras e em mediana + valores mínimo e máximo para cada grupo 
de dados nos gráficos em barras flutuantes (floating bars). Para verificação do cumprimento dos pressupostos de normalidade (distribuição normal dentro de um conjunto de dados) foi utilizado o teste de D'Agostino-Pearson. Dados paramétricos foram comparados com grupo controle através do teste de Dunnet e entre si através do teste de Tukey. As análises estatísticas foram realizadas com auxílio do programa GraphPad Prism 6.0 (Graph Pad Software®, La Jolla, CA, EUA).

\section{Resultados e Discussão}

\subsection{Extração e purificação das pectinas da parede celular de mamões maduros}

Partindo-se de triplicatas de amostra de mamão papaia congeladas do sexto dia pós colheita (6DPC), conforme descrito em 3.1 e 3.2, o rendimento médio obtido foi de $1,83 \% \pm 0,11$ de fração celular total (FCT) sobre a massa fresca de fruto.

Após a extração da fração solúvel em água (FSA) a partir da fração celular total (FCT), foi obtida massa final de $0,177 \mathrm{~g} \pm 0,006$, com rendimento de $48,18 \%$ $\pm 8,7$ com relação à FCT. Desta forma, houve rendimento final de 0,88\% $\pm 0,10$ de FSA com relação à massa fresca do fruto, corroborando com o descrito em KOUBALA, et al. (2014) e PRADO, et al. (2016).

\subsection{Composição em monossacarídeos da pectina do mamão}

A determinação da composição em monossacarídeos da pectina de mamão papaia extraída se faz necessária a fim de se delimitar com clareza quais são os açúcares que estarão atuantes na atividade biológica do polissacarídeo utilizado, bem como o teor de cada um deles na amostra.

Os dados brutos das análises realizadas conforme descrito em 3.3.1 estão representados a seguir (média \pm desvio-padrão), em gráfico de barras (Figura 4): 


\section{Composição em Monossacarídeos}

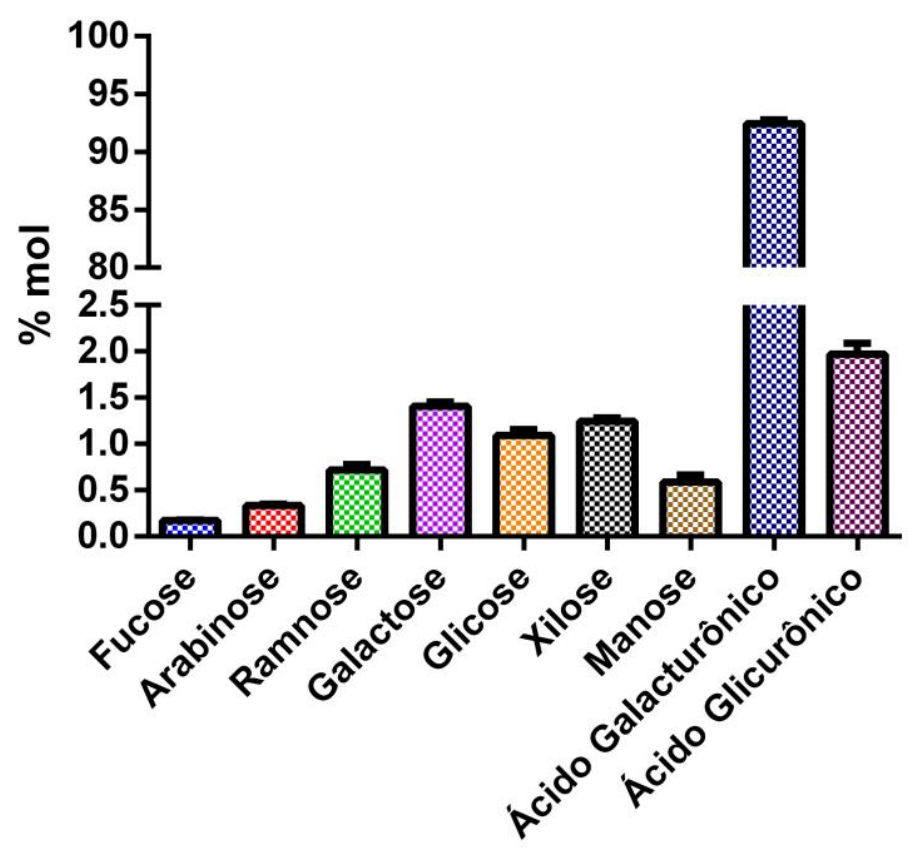

Monossacarídeos

Figura 4. Gráfico em barras dispondo os valores obtidos em \% (mol) para cada monossacarídeo constituinte da amostra de pectina de mamão papaia avaliada. Dados representados como média \pm desvio padrão de triplicatas das amostras.

Avaliando os dados obtidos, é possível inferir que a FSA obtida é formada, em sua grande parte, por pectina consistindo majoritariamente de ácido galacturônico $(92,5 \%)$, caracterizando as estruturas de homogalacturonanos predominantes da amostra (HARHOLT, 2010), com frações menores dos demais açúcares neutros sendo os de maiores proporções a galactose e a xilose.

Tendo em vista que a amostra de mamão papaia utilizada para extração da pectina consistiu de frutos com 6 dias de amadurecimento pós-colheita, os teores de monossacarídeos obtidos nos experimentos apresentaram comportamento esperado para o período de amadurecimento considerado. De acordo com descrito por PRADO et al. (2016), a pectina do mamão papaia apresenta aumento considerável das concentrações de ácido galacturônico e galactose nas frações solúveis em água ao longo de seu amadurecimento, devido à hidrólise dos açúcares complexos pela ação de enzimas endógenas. PRADO et al. (2017), utilizando a mesma amostragem de amadurecimento de mamões, mas de frutos do dia $1^{\circ}$ ao $4^{\circ}$ após a colheita, verificaram através de 
análise de ligações de carboidratos que as pectinas de mamões, possuem em sua estrutura, arabinogalactanos do tipo II. Os resultados aqui demonstrados corroboram com os dados expostos em PRADO et al. (2017), considerando a quantidades dos monossacarídeos em predominância, bem como com 0 comportamento esperado no processo de amadurecimento deste fruto.

A tabela a seguir, apresenta os valores em \% molar dos monossacarídeos da amostra utilizada:

\begin{tabular}{l}
\hline \multicolumn{10}{c|}{ Tabela 1. Composição em monossacarídeos (\% molar) } \\
\hline
\end{tabular}

A Tabela 1 foi construída considerando os dados em \% molar dos monossacarídeos constituintes da amostra de FSA utilizada, através do método descrito em 3.3.1.

A determinação estimada de teor em homogalacturonanos e ramnogalacturonanos do tipo I foi realizada utilizando a equação proposta por M'SAKNI, et al. (2006), exposta a seguir:

- $H G(\%)=$ GalA (\%) - Ram (\%)

- $\mathrm{RG}-\mathrm{I}(\%)=[\mathrm{GalA}(\%)-\mathrm{HG}(\%)]+\operatorname{Ram}(\%)+\operatorname{Ara}(\%)+$ Gal $(\%)$

Os dados expostos delimitam e são capazes de predizer a composição das frações pécticas da amostra utilizada, permitindo inferir que, conforme descrito anteriormente, a amostra é composta majoritariamente de homogalacturonanos, contendo frações discretas de ramnogalacturonanos do tipo I. 


\subsection{Determinação da homogeneidade e peso molecular de polissacarídeos da FSA de pectina do mamão papaia}

Conforme descrito em 3.3.2, de acordo com os tempos de retenção $\left(T_{r}\right)$ obtidos para cada padrão utilizado, obteve-se a seguinte equação da reta: $y=-$ $0,1954 x+12,70\left(R^{2}=0,997\right)$. Os tempos de retenção relativos a cada padrão de peso molecular estão representados a seguir (Tabela 2):

\begin{tabular}{l}
\hline $\begin{array}{c}\text { Tabela 2. Correlação entre os } \\
\text { tempos de retenção e respectivos } \\
\text { padrões de peso molecular }\end{array}$ \\
\begin{tabular}{|c|c|}
\hline $\begin{array}{c}\text { Peso molecular } \\
\text { (kDa) }\end{array}$ & $\begin{array}{c}\text { Tempo de } \\
\text { retenção }\end{array}$ \\
\hline $\mathbf{5 , 0}$ & 45,742 \\
\hline $\mathbf{1 2 , 5}$ & 44,357 \\
\hline $\mathbf{2 5 , 0}$ & 42,514 \\
\hline $\mathbf{5 0 , 0}$ & 40,965 \\
\hline $\mathbf{8 0 , 0}$ & 39,900 \\
\hline $\mathbf{1 5 0 , 0}$ & 38,596 \\
\hline $\mathbf{4 1 0 , 0}$ & 36,191 \\
\hline $\mathbf{7 5 0 , 0}$ & 34,899 \\
\hline
\end{tabular}
\end{tabular}

O perfil cromatográfico da amostra analisada em triplicata está representado a seguir, em conjunto com a regressão linear obtida a partir dos padrões moleculares utilizados na análise. 


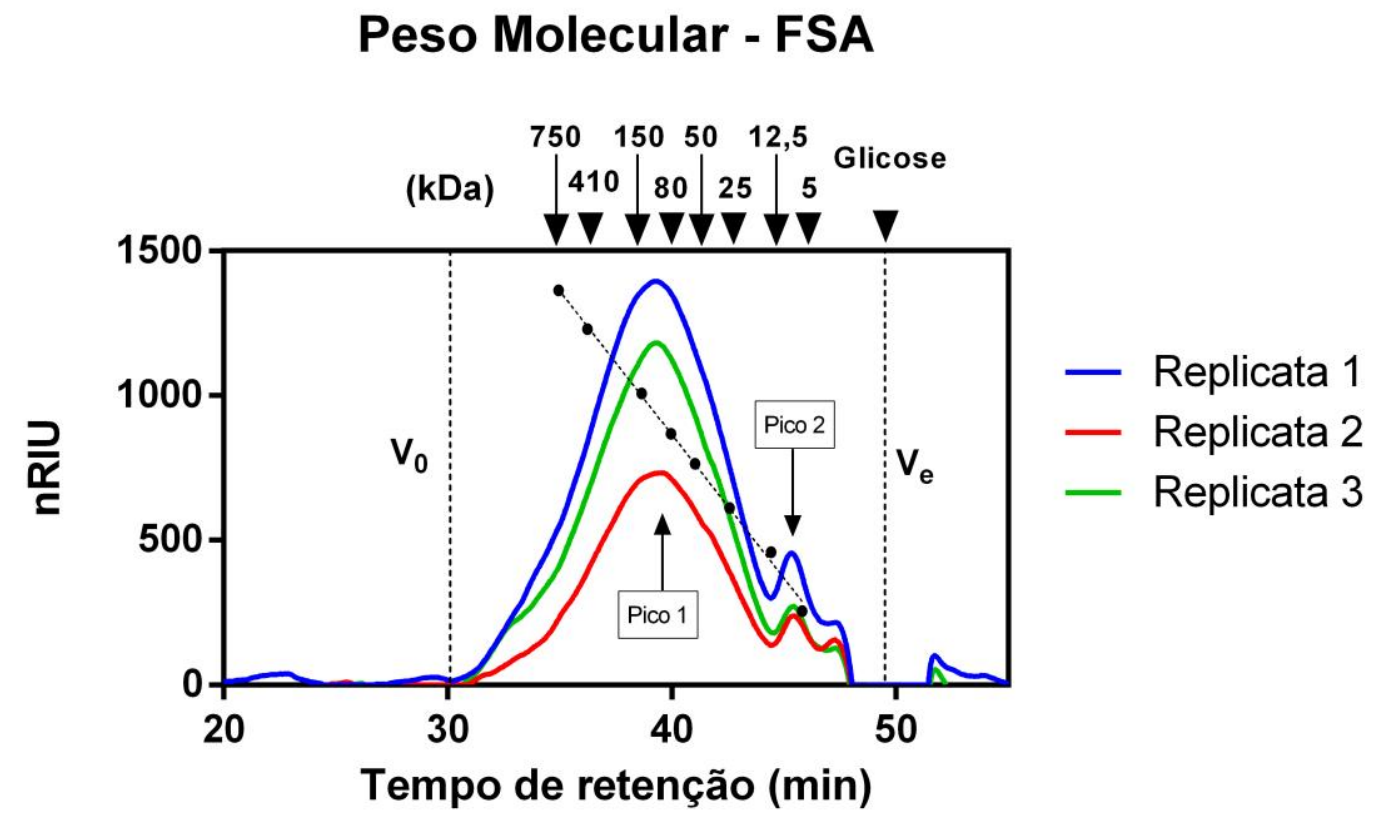

Figura 5. Sobreposição dos cromatogramas por exclusão de tamanho obtidos para cada replicata técnica da amostra de FSA. A reta pontilhada representa a regressão linear obtida a partir dos valores logarítmicos dos pesos moleculares dos padrões utilizados vs os tempos de retenção indicados na parte superior do cromatograma (Equação da reta: $y=-0,1954 x+12,70$; $\left.R^{2}=0,997\right)$. Separação realizada em coluna PL-aquagel-OH $(30,40,50$ e $60 ; 300 \times 7,5 \mathrm{~mm}$, porosidade $8,0 \mu \mathrm{m})$ conectadas em série. $\mathrm{V}_{0}$ : Volume de exclusão total (volume morto); $\mathrm{V}_{\mathrm{e}}$ : Volume de Permeação Total (volume de eluição).

A partir dos cromatogramas obtidos da amostra analisada e aplicação dos valores de Tr para cada pico em respectiva equação da reta (Figura 5), é possível calcular os valores de peso molecular para as frações de polissacarídeos presentes na amostra. Abaixo, estão representados os valores individuais dos picos para cada replicata da amostra.

Tabela 3. Valores de pesos moleculares obtidos por replicata em análise por HPSEC.

\begin{tabular}{|l|c|c|c|c|c|c|}
\hline \multirow{2}{*}{} & \multicolumn{2}{|c|}{ Replicata 1 } & \multicolumn{2}{c|}{ Replicata 2 } & \multicolumn{2}{c|}{ Replicata 3 } \\
\cline { 2 - 7 } & $\mathbf{T}_{\mathbf{r}}$ & $\begin{array}{c}\text { PM } \\
\mathbf{( k D a )}\end{array}$ & $\mathbf{T}_{\mathbf{r}}$ & $\begin{array}{c}\text { PM } \\
\mathbf{( k D a )}\end{array}$ & $\mathbf{T}_{\mathbf{r}}$ & $\begin{array}{c}\text { PM } \\
\text { (kDa) }\end{array}$ \\
\hline Pico 1 & 39,27 & 104,27 & 39,42 & 98,54 & 39,29 & 103,66 \\
\hline Pico 2 & 45,33 & 6,80 & 45,43 & 6,50 & 45,39 & 6,61 \\
\hline
\end{tabular}

Tr: Tempo de retenção; PM: peso molecular. 
Com base no exposto, pode-se afirmar que a amostra é composta de duas frações polissacarídicas com peso molecular de 102,16 kDa $\pm 3,04$, e 6,64 $\mathrm{kDa} \pm 0,12$ (expressos como média \pm desvio padrão por pico).

Tais valores aproximam-se do encontrado em amostras de mamão papaia com 3 e 4 dias de amadurecimento (PRADO, et al. 2017). Neste cenário, seria esperado que os picos apresentassem peso molecular reduzido, entretanto, ao longo do amadurecimento do fruto, pela ação das pectinases, ocorre migração de polissacarídeos anteriormente insolúveis em água, para a FSA, justificando o peso molecular semelhante encontrado para as frações extraídas de frutos no terceiro e quarto dia após a colheita (PRADO, et al. 2016).

\subsection{Determinação do teor de proteínas pelo método de Bradford}

A fim de garantir que a FSA extraída fosse composta apenas por carboidratos, fez-se necessário determinar a presença de possíveis contaminantes na amostra que pudessem, eventualmente, interagir com as células utilizadas no estudo. Para tal, foi realizada análise da presença de proteínas pelo método de Bradford, conforme descrito em 3.3.3. A imagem a seguir representa foto da placa obtida no experimento:

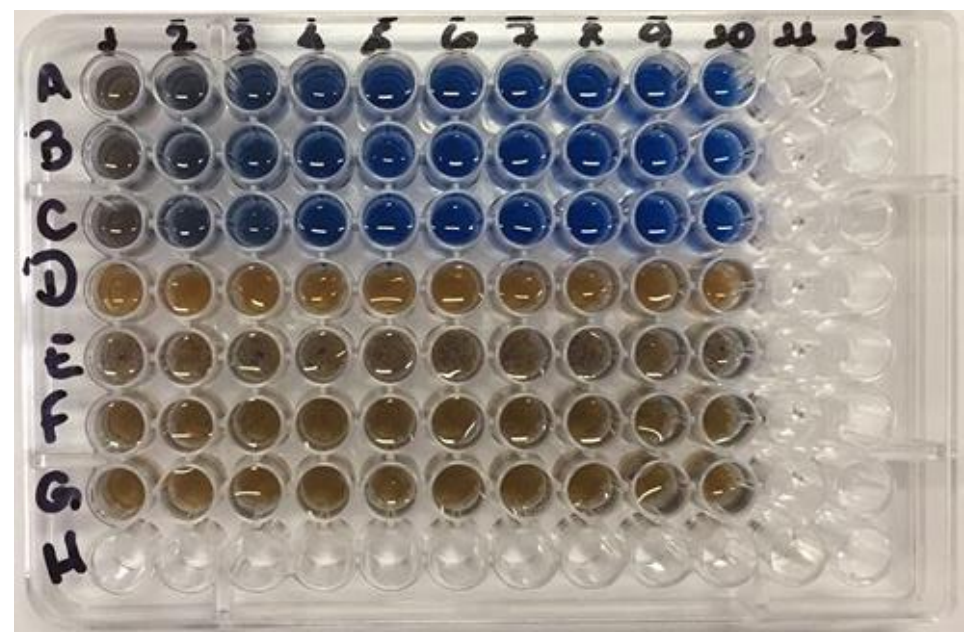

Figura 6. Amostra preparada em placa de 96 poços utilizada para análise de teor de proteínas pelo método de Bradford. Linhas A1 - A10, B1 - B10 e C1 - C10: Poços contendo 10 pontos de concentrações graduais de padrão analítico $(0,005 \mu \mathrm{g}$ Albumina/ $\mu \mathrm{L}-0,05 \mu \mathrm{g}$ Albumina/ $\mu \mathrm{L})$; Linha D1 - D10: Branco analítico; Linhas E1 - E10, F1 - F10 e G1 - G10: replicatas amostrais. 
A partir dos valores de absorbância obtidos, foi possível inferir que a amostra não possui quantidades significativas de proteínas, tido que os dados obtidos por amostra se encontraram abaixo do limite de detecção do método.

\subsection{Determinação da concentração de compostos fenólicos totais pelo método de Folin-Ciocalteau}

A determinação da presença de compostos fenólicos na amostra de FSA extraída faz-se necessária, tido que estas moléculas podem interferir na sobrevida de células tumorais através da modulação da expressão de NF-kB, por exemplo (GUTIÉRREZ-GRIJALVA et al., 2016), podendo produzir possíveis resultados falso-positivos.

Os resultados obtidos através da análise de placa de 96 poços em espectrofotômetro, preparada conforme método descrito em 3.3.4, demonstraram valores de absorbância menores do que o limite de detecção do método. Abaixo, está representada foto da placa preparada a partir da amostra analisada:

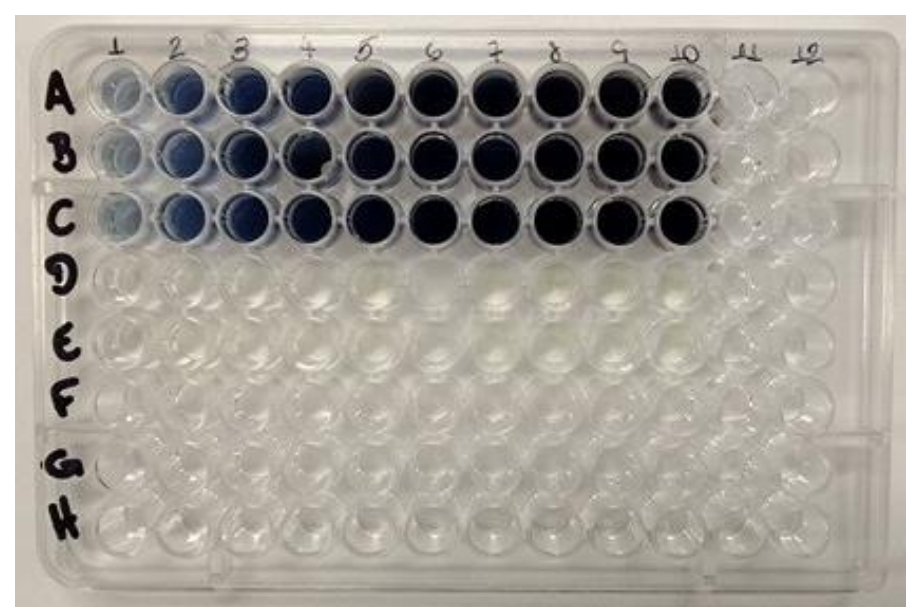

Figura 7. Amostra preparada em placa de 96 poços utilizada para análise de teor de compostos fenólicos pelo método de Folin-Ciocalteau. Linhas A1 - A10, B1 - B10 e C1 - C10: Poços contendo 10 pontos de concentrações graduais de padrão analítico $(0,0004$ EqAG - 0,004 EqAG); Linha D1 - D10: Branco analítico; Linhas E1 - E10: amostra. 


\subsection{Inibições químicas in vitro da GAL-3 e do TLR4}

\subsubsection{Tratamento 0: Inibidores químicos}

Conforme descrito em 3.4.2.1, as células cultivadas foram tratadas com os compostos responsáveis por promover a inibição química das proteínas de interesse, a fim de averiguar se estes poderiam alterar de alguma maneira a viabilidade das células estudadas. As Figuras 8 e 9, ilustradas a seguir, dispõem os resultados referentes à viabilidade celular (em porcentagem) das células tratadas com N-Acetil-Lactosamina (NAcLac) e com Resatorvid, respectivamente, considerando os tempos de 24,48 e 72 horas de tratamento.

\section{T0 - NAcLac}

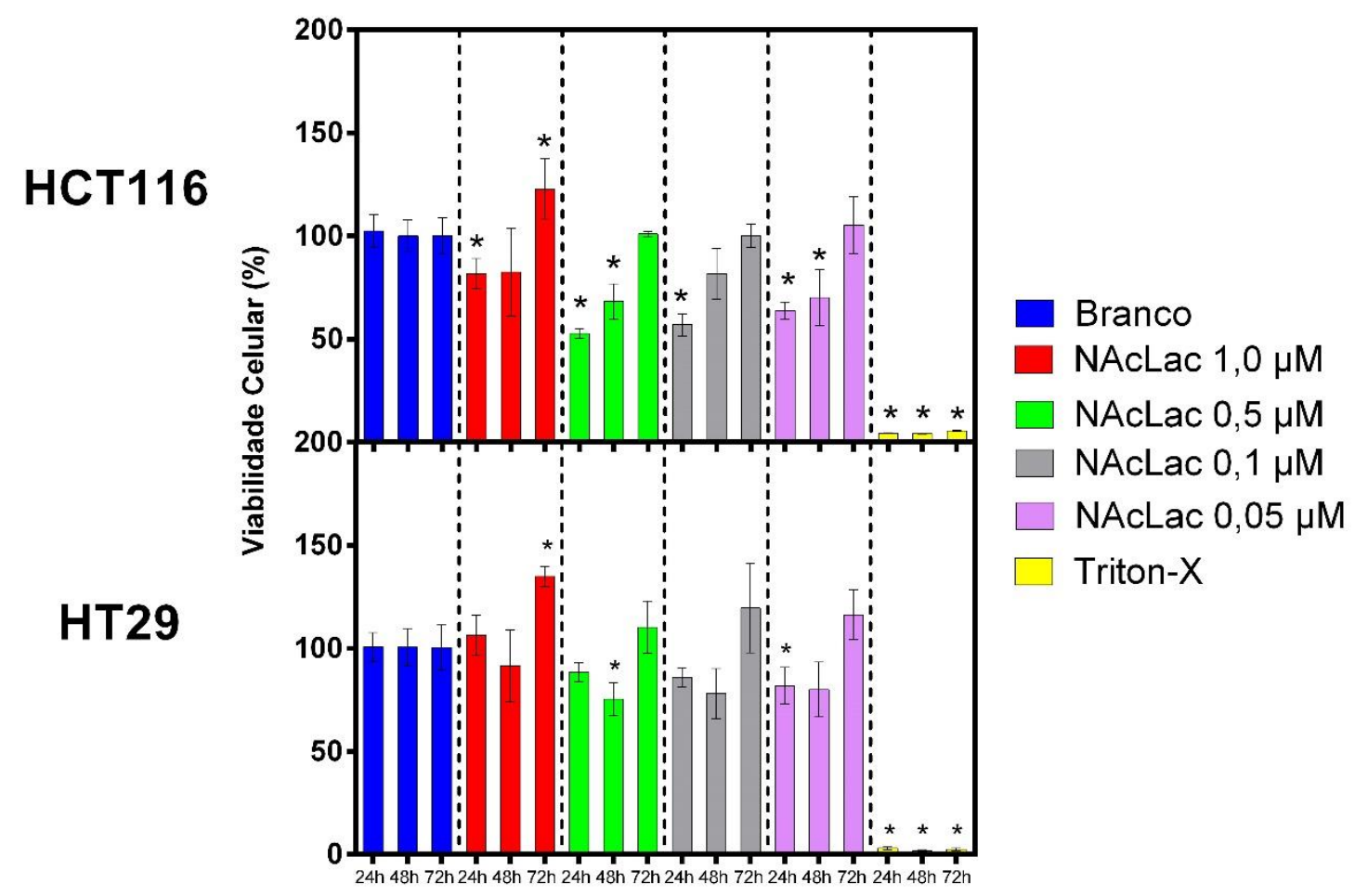

Figura 8. Gráficos em barras relacionando as viabilidades celulares (em porcentagem) de cada linhagem celular, tratadas com N-Acetil-Lactosamina em respectivos tempos de tratamento (24, 48 e 72 horas). Os asteriscos representam diferença estatística entre os valores de cada concentração utilizada em relação ao branco experimental relativo aos respectivos tempos de tratamento ( $p<0,05$; Teste de Dunnett). A ausência de asteriscos indica que não houve diferença estatística relevante.

Ao avaliar os gráficos representados na Figura 8, é possível inferir que 0 tratamento com o inibidor da GAL-3 foi capaz de produzir queda na viabilidade celular da linhagem HCT116, com relação ao branco experimental, no período 
de 24 horas, para as quatro concentrações utilizadas no experimento. A HT29 mostrou-se ligeiramente mais resistente ao tratamento. Percebe-se também que, ao longo do tempo, as linhagens recuperam sua viabilidade inicial. Conforme descrito em 3.4.2.1., experimentos foram repetidos com a suplementação dos inibidores ao longo das 24 e 48 horas, mas o comportamento de viabilidade permaneceu o mesmo.

Podem ser vários os motivos pelos quais se observou um efeito de queda da viabilidade. Entretanto, devido ao contraponto de que essa queda não foi dose dependente, pode-se especular que o estresse que as células sofreram após 0 tratamento, ao serem submetidas à presença de um composto originalmente estranho ao meio de cultura, pode ter sido determinante na queda de viabilidade, especialmente devido ao fato destas recuperarem a sua viabilidade ao longo do período de tempo estudado.

\section{T0 - Resatorvid}

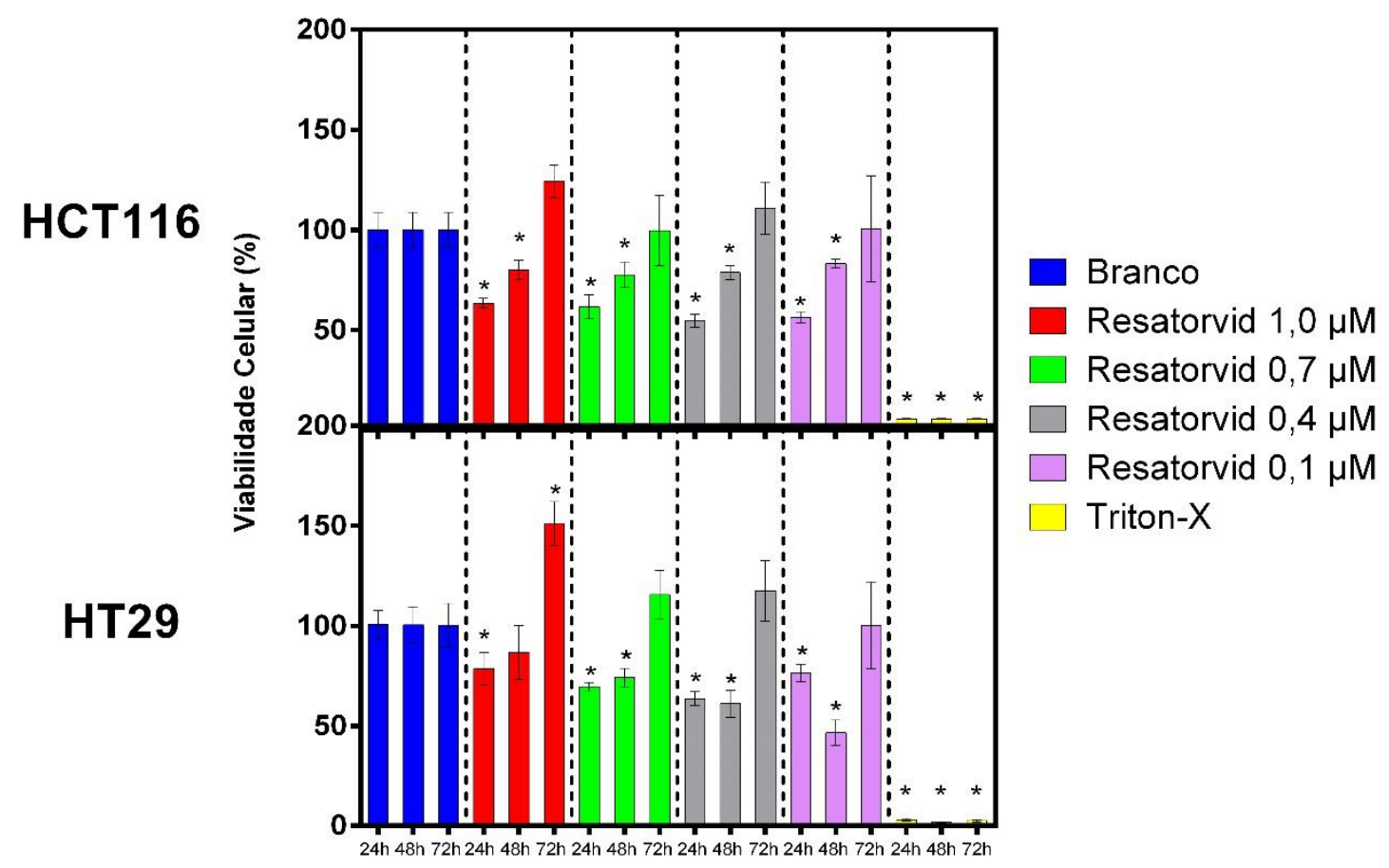

Figura 9. Gráficos em barras relacionando as viabilidades celulares (em porcentagem) de cada linhagem celular, tratadas com Resatorvid em respectivos tempos de tratamento (24, 48 e 72 horas). Os asteriscos representam diferença estatística entre os valores de cada concentração utilizada em relação ao branco experimental relativo aos respectivos tempos de tratamento $(p<$ 0,05 ; teste de Dunnett). A ausência de asteriscos indica que não houve diferença estatística relevante. 
Assim como observado na Figura 8, inicialmente as células tratadas com resatorvid apresentaram queda na sua viabilidade em 24 horas de tratamento, com recuperação ao longo do tempo. Entretanto, diferentemente do que foi observado no tratamento com NAcLac, a HT29 apresentou maior sensibilidade ao tratamento com Resatorvid, de acordo com o observado em Figura 9.

A queda da viabilidade da HCT116 após o tratamento com Resatorvid reforça a hipótese anterior para o tratamento com NAcLac de que as células sofreram estresse resultante da inserção de moléculas estranhas ao meio de cultivo. Dado o fato desta linhagem expressar o receptor TLR4 não-funcional, não seria esperado haver alteração de suas atividades metabólicas, ao menos não por ação direta do composto utilizado.

Quanto à HT29, observa-se que o tratamento com o inibidor da sinalização do receptor TLR4, na concentração de 1,0 $\mu \mathrm{M}$ foi capaz de, ao longo do tempo, promover elevação acentuada da viabilidade celular. Este efeito pode ter sido observado provavelmente por efeito protetor do composto utilizado, já que a molécula é capaz de impedir a cascata de sinalizações promovida pela ativação do receptor TLR4. A linhagem poderia, por alguma razão não estudada no presente trabalho, estar exposta a um estado de estresse oxidativo resultante de estímulo ao TLR4 constante que manteria a viabilidade celular equilibrada. Uma vez que se tenha a diminuição da sinalização do TLR4, pode-se ter uma diminuição de uma possível resposta inflamatória com consequente diminuição de liberação de radicais livres de oxigênio, permitindo assim uma diminuição da morte celular e uma consequente elevação da viabilidade celular observada.

\subsubsection{Efeito dos tratamentos concomitantes ( $\mathrm{T} 1, \mathrm{~T} 2$, $\mathrm{T} 3$ e $\mathrm{T} 4)$ em HCT116}

Os gráficos obtidos a partir de cada tratamento (realizados conforme descrito em 3.4.2.2; 3.4.2.3; 3.4.2.4 e 3.4.2.5) em linhagem HCT116 estão dispostos a seguir (Figura 10): 
HCT116

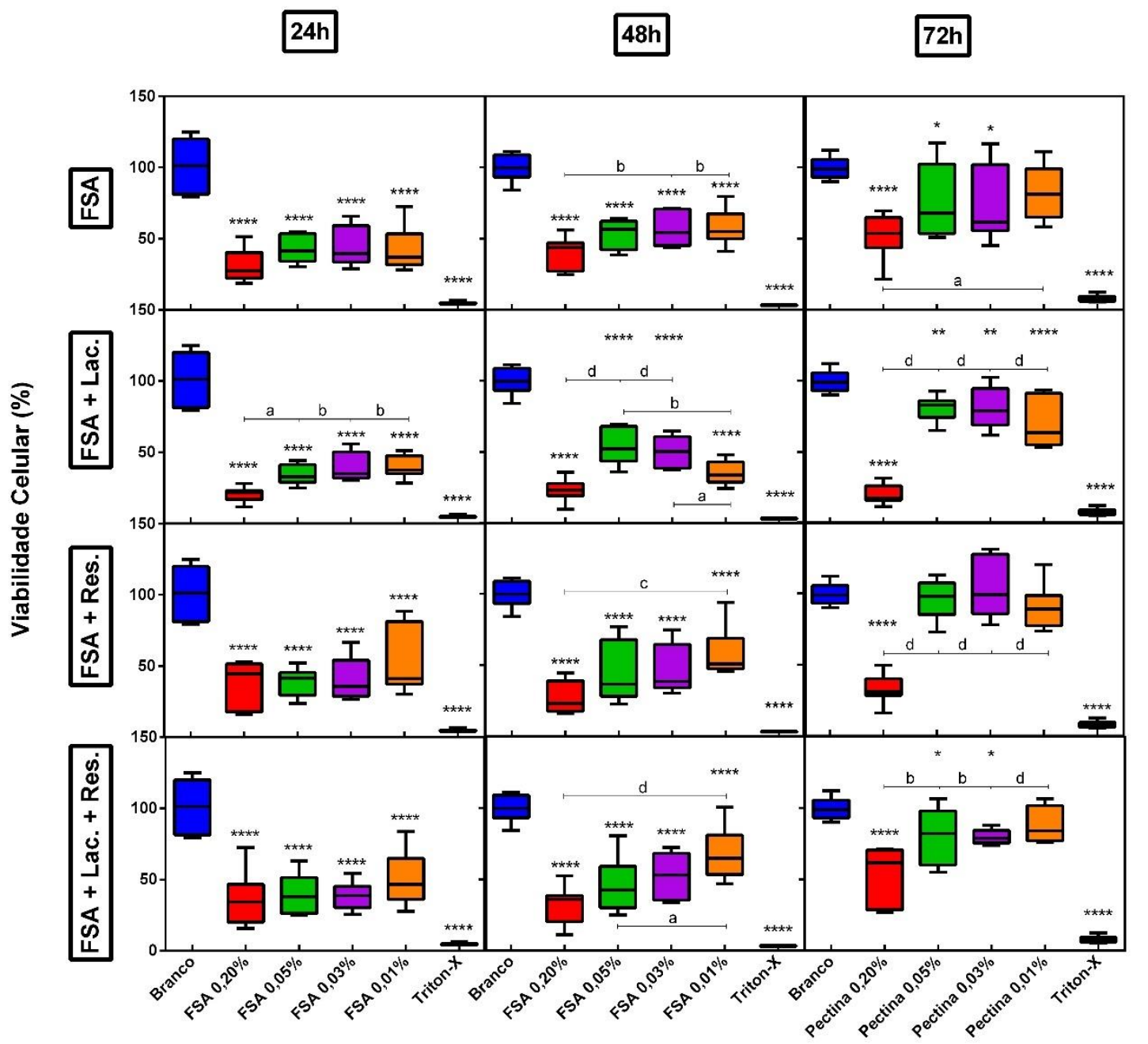

Figura 10. Gráficos de viabilidade celular (em porcentagem) da linhagem HCT116 representados como barras flutuantes para cada tratamento (pontos mínimos, pontos máximos e mediana), em cada período de tempo considerado. Os asteriscos representam, em ordem crescente de relevância, a diferença estatística obtida entre os dados comparados com o branco experimental, de acordo com teste de Dunnett $\left({ }^{*}-p \leq 0,05 ;{ }^{* *}-p \leq 0,01 ;{ }^{* * *}-p \leq 0,001 ;{ }^{* * *}-p \leq 0,0001 ; n=\right.$ 9). As letras representam, em ordem crescente de relevância, a diferença estatística obtida da comparação entre os grupos de dados considerados, de acordo com teste de Tukey, onde cada marcação presente na barra horizontal imediatamente abaixo da letra representa a comparação entre o grupo de dados considerado no início da barra, com o grupo de dados indicado pela marcação ( $a-p \leq 0,05 ; b-p \leq 0,01 ; c-p \leq 0,001 ; d-p \leq 0,0001 ; n=9$ ). FSA: Fração Solúvel em Água (T1); FSA + Lac.: Fração Solúvel em Água + N-Acetil-Lactosamina (T2); FSA + Res.: Fração Solúvel em Água + Resatorvid (T3); FSA + Lac. + Res.: Fração Solúvel em Água + NAcetil-Lactosamina + Resatorvid (T4). 
Ao avaliar os gráficos de viabilidade celular dispostos na Figura 10, é possível observar que houve queda na viabilidade celular no tempo de 24 e 48 horas para os 4 tratamentos concomitantes realizados. Às 72 horas, percebe-se que a queda da viabilidade foi mantida com maior relevância quando utilizada FSA em concentração de $0,2 \%$, sendo observável lenta recuperação da viabilidade nos demais tratamentos. Sendo assim, é possível inferir que a queda da viabilidade apresenta relação de dose-dependência para os tratamentos com as pectinas dos mamões.

Observa-se também que para esta linhagem celular, o tratamento realizado em T2 (FSA + NAcLac), produziu queda de viabilidade celular mais acentuada e duradoura que observado nos demais tratamentos, indicando que a inibição da GAL-3 é um fator importante para a eficácia da ação da FSA extraída. Conforme mencionado anteriormente, sabe-se que as pectinas utilizadas neste estudo não inibiram a GAL-3 em testes prévios realizados pelo grupo. Ao observar que uma pectina que não inibe a GAL-3 tem o efeito de diminuição de viabilidade exacerbado utilizando um inibidor de GAL-3 (T2), confirma-se que essa inibição pode ter papel secundário no efeito biológico, mas não menos importante. Além disso, ao se observar que em T3 (FSA + Resatorvid) ocorreu menor queda da viabilidade celular, quando em comparação com o observado em T2, pode-se supor que a ação da FSA extraída esteja relacionada com o estímulo dos receptores TLR4 e/ou um outro mecanismo complementar ainda não elucidado.

Curiosamente, ao avaliar a viabilidade obtida em T4, percebe-se que, ao longo do tempo, a inibição concomitante das duas proteínas estudadas aparenta promover redução do efeito de queda de viabilidade promovido pela FSA, demonstrando que ambos os fenômenos de inibição da GAL-3 e do TLR4 podem alterar os efeitos anti-proliferativos das pectinas de mamões.

\subsubsection{Efeito dos tratamentos concomitantes (T1, T2, T3 e T4) em HT29}

Os gráficos obtidos a partir de cada tratamento (realizados conforme descrito em 3.4.2.2; 3.4.2.3; 3.4.2.4 e 3.4.2.5) em linhagem HT29 estão dispostos a seguir (Figura 11): 


\section{HT29}

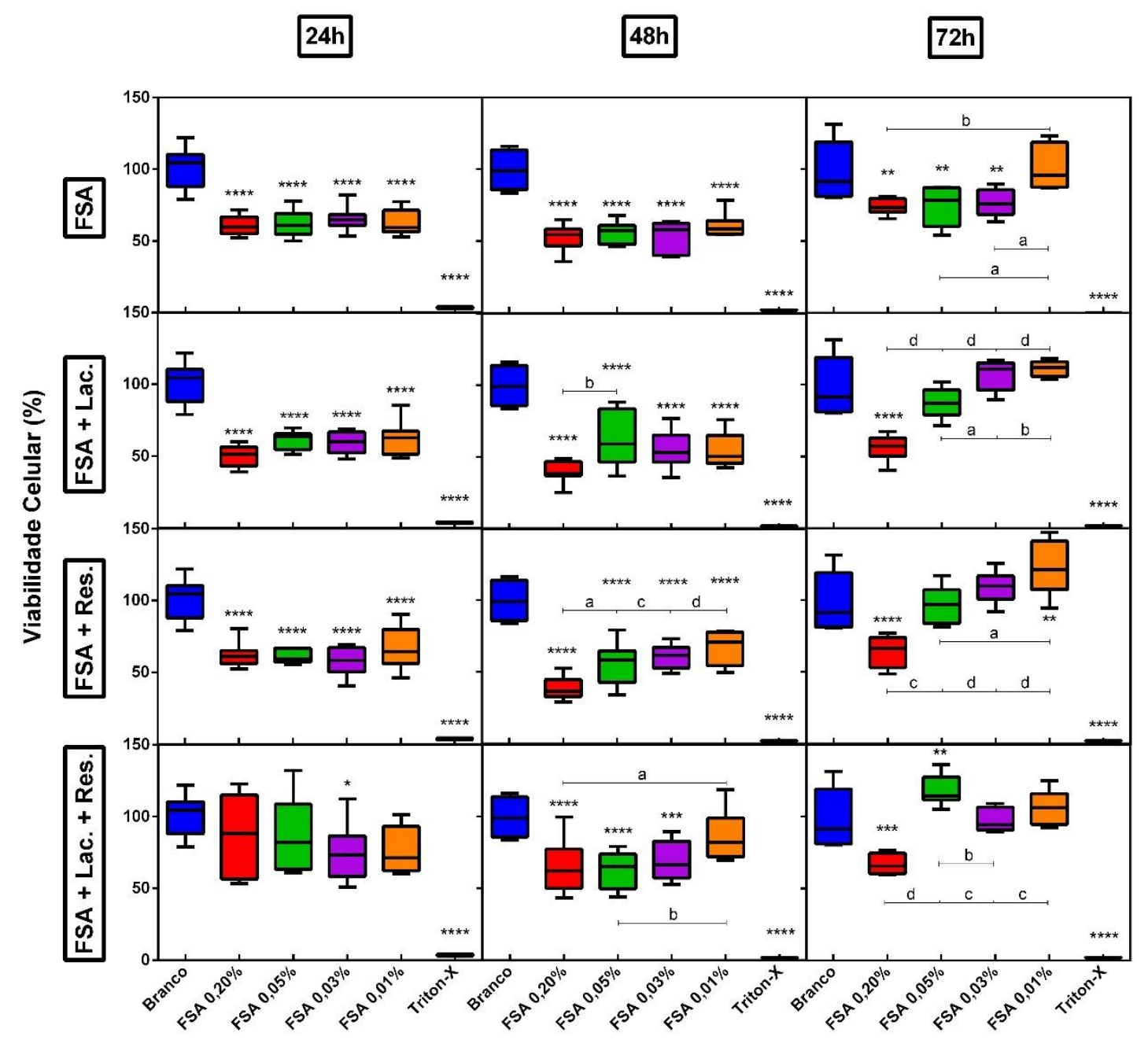

Figura 11. Gráficos de viabilidade celular (em porcentagem) da linhagem HT29 representados como barras flutuantes para cada tratamento (pontos mínimos, pontos máximos e mediana), em cada período de tempo considerado. Os asteriscos representam, em ordem crescente de relevância, a diferença estatística obtida entre os dados comparados com o branco experimental, de acordo com teste de Dunnett $\left({ }^{*}-p \leq 0,05 ;{ }^{* *}-p \leq 0,01 ;{ }^{* * *}-p \leq 0,001 ;{ }^{* * * *}-p \leq 0,0001 ; n=\right.$ 9). As letras representam, em ordem crescente de relevância, a diferença estatística obtida da comparação entre os grupos de dados considerados, de acordo com teste de Tukey, onde cada marcação presente na barra horizontal, imediatamente abaixo da letra, representa a comparação entre o grupo de dados considerado no início da barra, com o grupo de dados indicado pela marcação ( $a-p \leq 0,05 ; b-p \leq 0,01 ; c-p \leq 0,001 ; d-p \leq 0,0001 ; n=9)$. FSA: Fração Solúvel em Água (T1); FSA + Lac.: Fração Solúvel em Água + N-Acetil-Lactosamina (T2); FSA + Res.: Fração Solúvel em Água + Resatorvid (T3); FSA + Lac. + Res.: Fração Solúvel em Água + NAcetil-Lactosamina + Resatorvid (T4). 
A Figura 11 permite concluir que, assim como observado na linhagem HCT116, as células HT29 apresentam queda de sua viabilidade quando tratadas com a FSA rica em pectinas em uma relação dose-dependente. Entretanto, diferentemente do que foi observado na outra linhagem celular, a HT29 apresenta queda menos acentuada aos tratamentos em 24 horas, com maior queda às $48 \mathrm{~h}$, e ligeira recuperação às $72 \mathrm{~h}$ de tratamento, dados estes que corroboram com os dados obtidos por Prado et al. (2017), ao menos com relação às amostras extraídas de mamões maduros do terceiro dia após a colheita. Os tratamentos de FSA isoladamente com os respectivos inibidores químicos (T2 e T3) promoveram redução da viabilidade celular de maneira similar entre si, enquanto que o tratamento com os inibidores em concomitância (T4), novamente pareceu promover certa proteção contra o efeito da FSA utilizada, visto que não só a queda da viabilidade foi menos acentuada, como ocorreu uma aparente perda da relação dose-dependente do efeito de FSA, conforme observado no tratamento em 72 horas.

\subsubsection{Comparação entre os tratamentos e as linhagens celulares}

Ao comparar os tratamentos realizados, levando em consideração apenas a maior concentração de FSA utilizada nos experimentos $(0,2 \%)$, é possível visualizar que a linhagem HCT116 apresenta queda de viabilidade acentuada com 24 horas de tratamento, que se mantém ao longo do período observado, para os tratamentos T1, T2 e T3, de forma que o tratamento concomitante com $\mathrm{N}$-Acetil-Lactosamina produziu maior impacto na viabilidade. Em T4, é possível observar ligeira recuperação da viabilidade em 72 horas de tratamento. 
HCT116 HT29

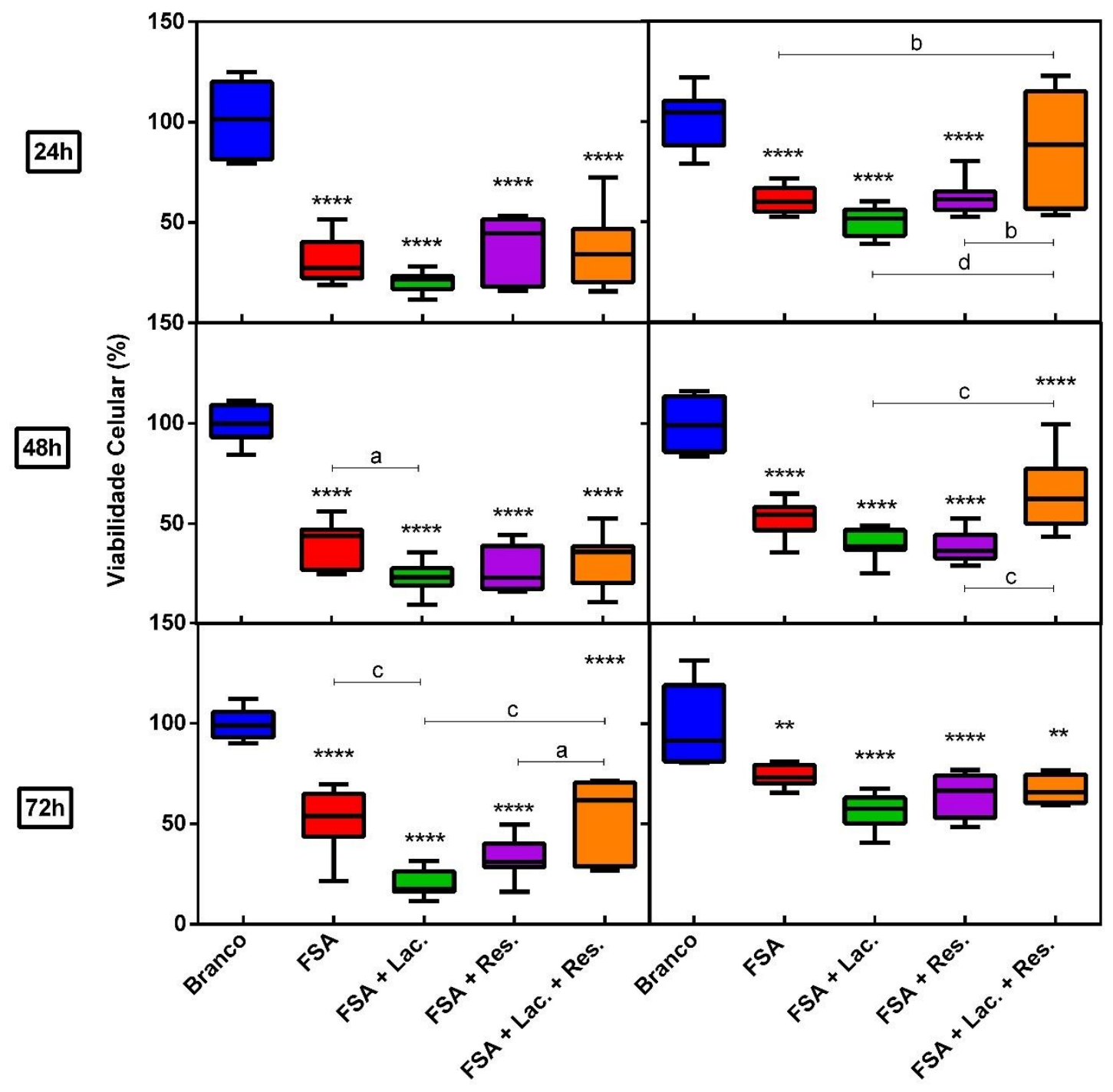

Pectina $0,2 \%$

Figura 12. Gráficos de viabilidade celular (em porcentagem) referentes aos quatro tratamentos realizados com FSA da pectina extraída, conforme tempo de tratamento e linhagem utilizada, representados como barras flutuantes para cada tratamento (pontos mínimos, pontos máximos e mediana). Os asteriscos representam, em ordem crescente de relevância, a diferença estatística obtida entre os dados comparados com o branco experimental de acordo com teste de Dunnett $\left({ }^{*}-p \leq 0,05 ;{ }^{* *}-p \leq 0,01 ;{ }^{* * *}-p \leq 0,001 ;{ }^{* * * *}-p \leq 0,0001 ; n=9\right)$. As letras representam, em ordem crescente de relevância, a diferença estatística obtida da comparação entre os grupos de dados considerados, de acordo com teste de Tukey, onde cada marcação presente na barra horizontal imediatamente abaixo da letra representa a comparação entre 0 grupo de dados considerado no início da barra, com o grupo de dados indicado pela marcação $(a-p \leq 0,05 ; b-p \leq 0,01 ; c-p \leq 0,001 ; d-p \leq 0,0001 ; n=9)$. FSA: Fração Solúvel em Água (T1); FSA + Lac.: Fração Solúvel em Água + N-Acetil-Lactosamina (T2); FSA + Res.: Fração Solúvel em Água + Resatorvid (T3); FSA + Lac. + Res.: Fração Solúvel em Água + N-AcetilLactosamina + Resatorvid (T4). 
Com relação à HT29, observa-se que esta linhagem não apresenta tanta sensibilidade à FSA da pectina de mamão quanto a HCT116, conforme já observado anteriormente (Prado et al., 2017), além de apresentar recuperação de viabilidade mais pronunciada ao longo do tempo. Além disso, verifica-se que os tratamentos demonstraram diferenças de capacidade de redução da viabilidade celular apenas entre 24 e 48 horas, demonstrando que, aparentemente, a linhagem HT29 é capaz de adaptar-se às condições adversas do ambiente com maior facilidade que a HCT116.

Conforme explicitado anteriormente, sabe-se que a amostra utilizada não é capaz de promover inibição da GAL-3, justificando o fato da queda da viabilidade em T3 não ser tão significativa quando em T2, especialmente para a linhagem HCT116, dentro deste modelo experimental. Estes dados reforçam a possibilidade de as pectinas estimularem a via necroptótica observada por Prado, et al. (2017), possivelmente pela interação com receptores TLR3, especialmente com relação à linhagem HCT116, que os expressa em maior abundância com relação aos receptores TLR4 (KLIMOSCH, 2013; ZHAO, 2007). Neste contexto, destaca-se também a importância da inibição da GAL-3 para o efeito de queda da viabilidade das células tumorais promovido pelas pectinas utilizadas, tido que em ambas as linhagens se observou a manutenção de níveis reduzidos de viabilidade com relação ao branco experimental.

\subsubsection{População celular final após tratamentos concomitantes (T1, T2, T3 e T4) em HCT116 e HT29, in vitro.}

Após a obtenção da curva padrão de crescimento (descrita em 3.4.4.) foi possível refletir os valores populacionais obtidos ao fim do teste de viabilidade celular por redução do MTT, com seus respectivos valores de absorbância. A Figura 13, exposta a seguir, ilustra as populações celulares obtidas ao longo dos tratamentos realizados conforme descritos em 3.4.3., nos tempos de 24, 48 e 72h. Considerando que os dados relativos aos tratamentos utilizando concentrações de FSA de $0,20 \%$ foram os que representaram maior impacto ao metabolismo celular, as curvas de crescimento representadas a seguir, referemse às populações tratadas com FSA 0,2\%. 


\section{Curva de crescimento HCT116}

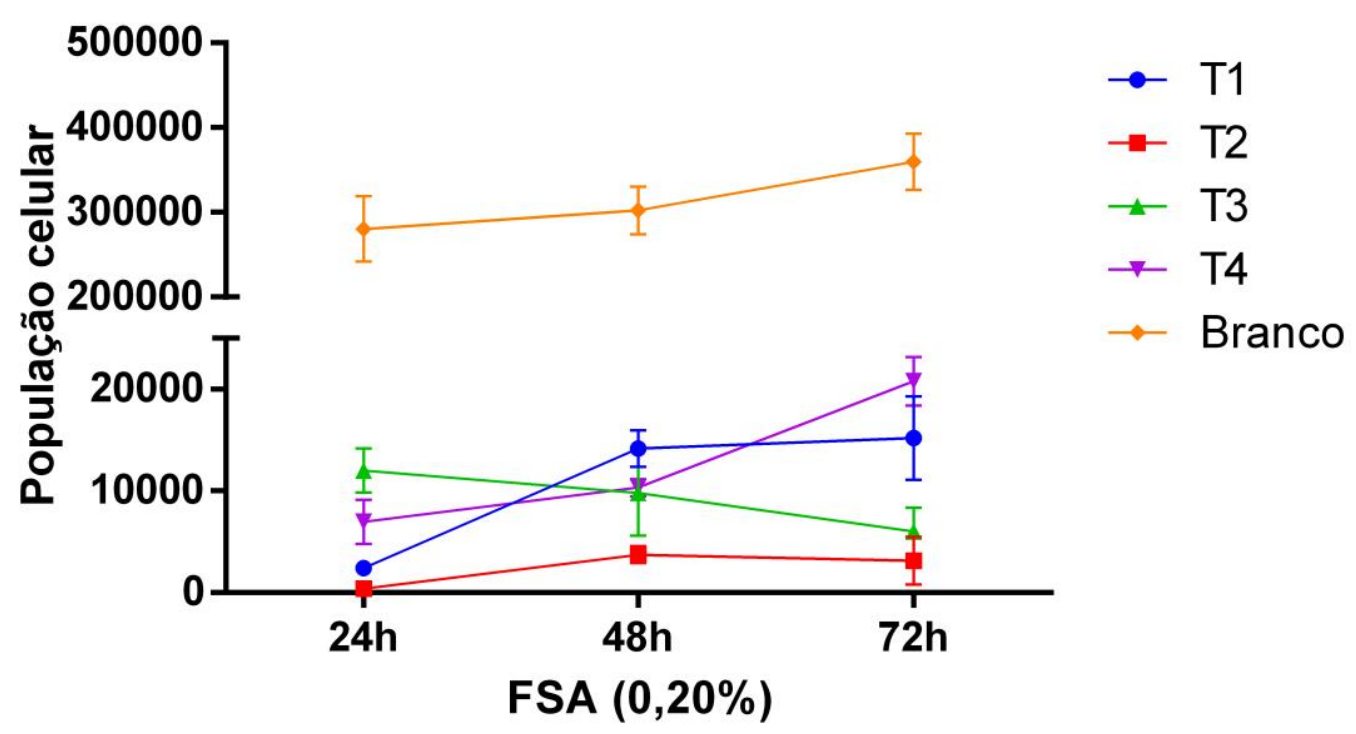

\section{Curva de crescimento HT29}

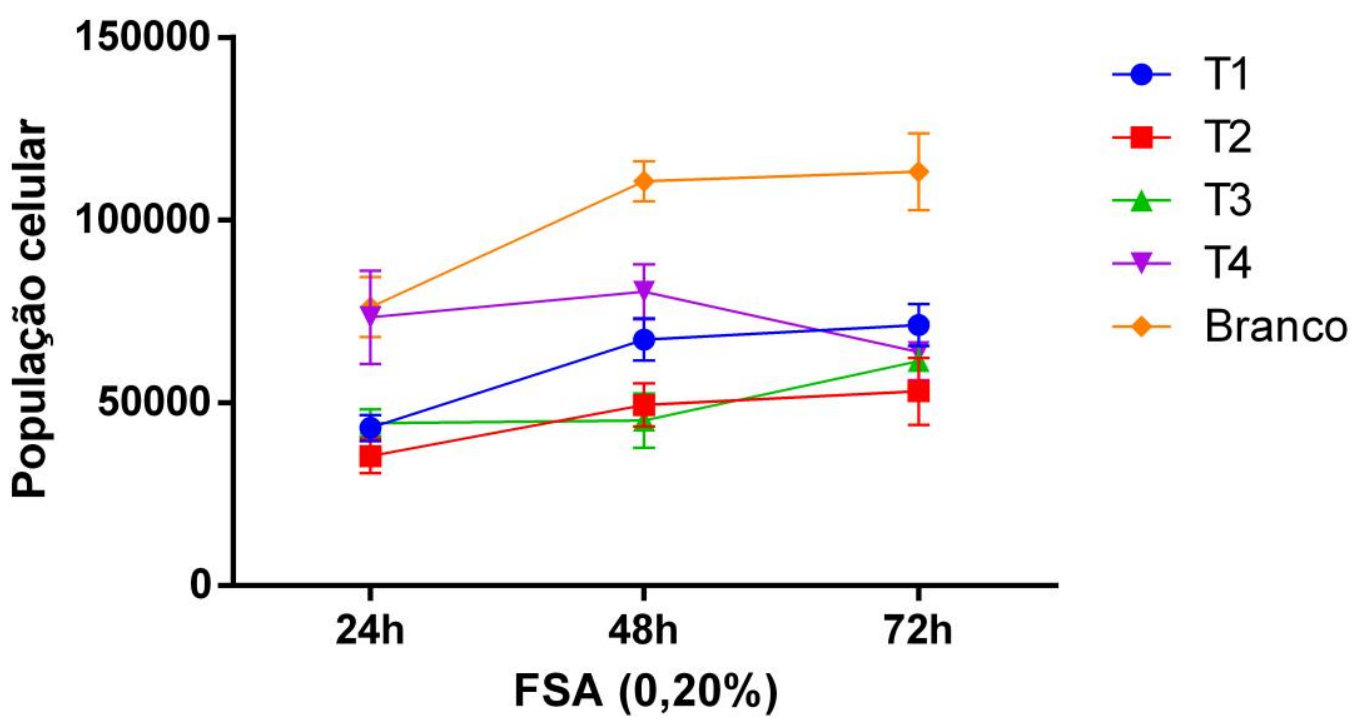

Figura 13. Gráficos das curvas de crescimento das linhagens HCT116 e HT29. Branco: Cultura de células sem tratamentos; T1: Fração Solúvel em Água; T2: Fração Solúvel em Água + NAcetil-Lactosamina; T3: Fração Solúvel em Água + Resatorvid; T4: Fração Solúvel em Água + $\mathrm{N}$-Acetil-Lactosamina + Resatorvid 
Os valores de viabilidade foram calculados com base nas seguintes regressões lineares obtidas a partir das curvas de calibração, produzidas conforme descrito em 3.4.4:

- HCT116

O Eq. da reta: $y=3,633 \times 10^{-5} x+0,3255 ; R^{2}=0,9617$

- HT29

O Eq. da reta: $y=2,432 \times 10^{-5} x+0,1385 ; R^{2}=0,9843$

Conforme observado no ensaio de viabilidade celular por redução do MTT, a curva de crescimento permitiu visualizar que, de fato, para ambas as linhagens celulares, T2 foi o tratamento que produziu a maior queda na população celular nas condições avaliadas, seguido por T3. Através do disposto, é possível confirmar que a inibição da atividade da GAL-3, in vitro, permite que a FSA de mamão papaia promova com maior intensidade a queda populacional das linhagens avaliadas. É possível notar também que a queda na população celular ocorre já nas primeiras $24 \mathrm{~h}$ de tratamento em ambas as linhagens celulares (com exceção de T4 em HT29), de tal forma que este perfil de queda se mantém em T3 para HCT116, e em T4 para HT29, corroborando com o exposto em 4.6.4.

\subsection{Knock-out gênico da expressão de GAL-3 e TLR4 via CRISPR-Cas9, e seleção celular por citometria de fluxo (FACS)}

As tentativas de knock-out da expressão das proteínas GAL-3 e TLR4 nas linhagens celulares utilizadas no trabalho foram realizadas conforme descrito em 3.4.5., para ambas as linhagens celulares. Entretanto, apenas a linhagem HCT116 sobreviveu às transformações. Algumas imagens representativas obtidas através de microscopia ótica de fluorescência são apresentadas a seguir. 


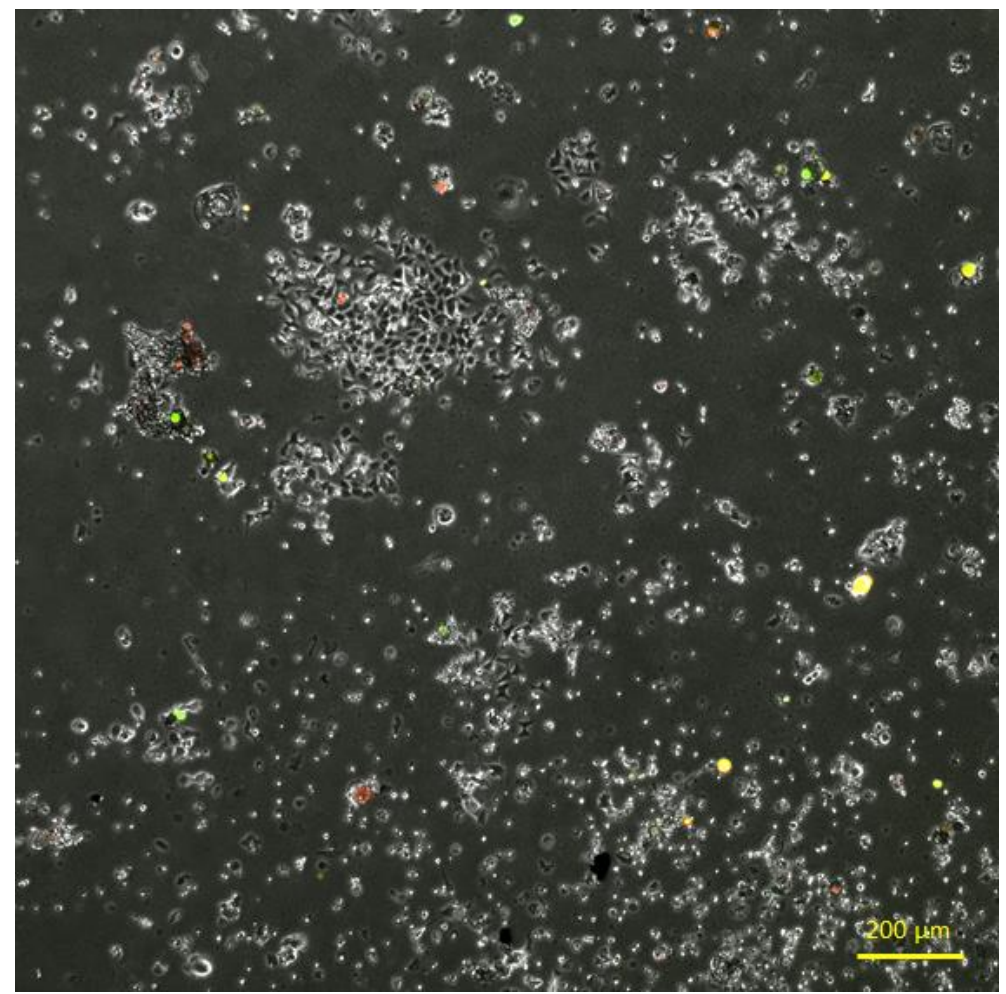

Figura 14. Microscopia ótica de fluorescência de cultura de células HCT116 após mutação gênica com sistema CRISPR-Cas9 para KO da expressão de GAL-3. Sobreposição de campos $B F+$ FITC + TRITC; visualização em aumento de 10x. Imagem obtida 3 dias após modificação gênica.

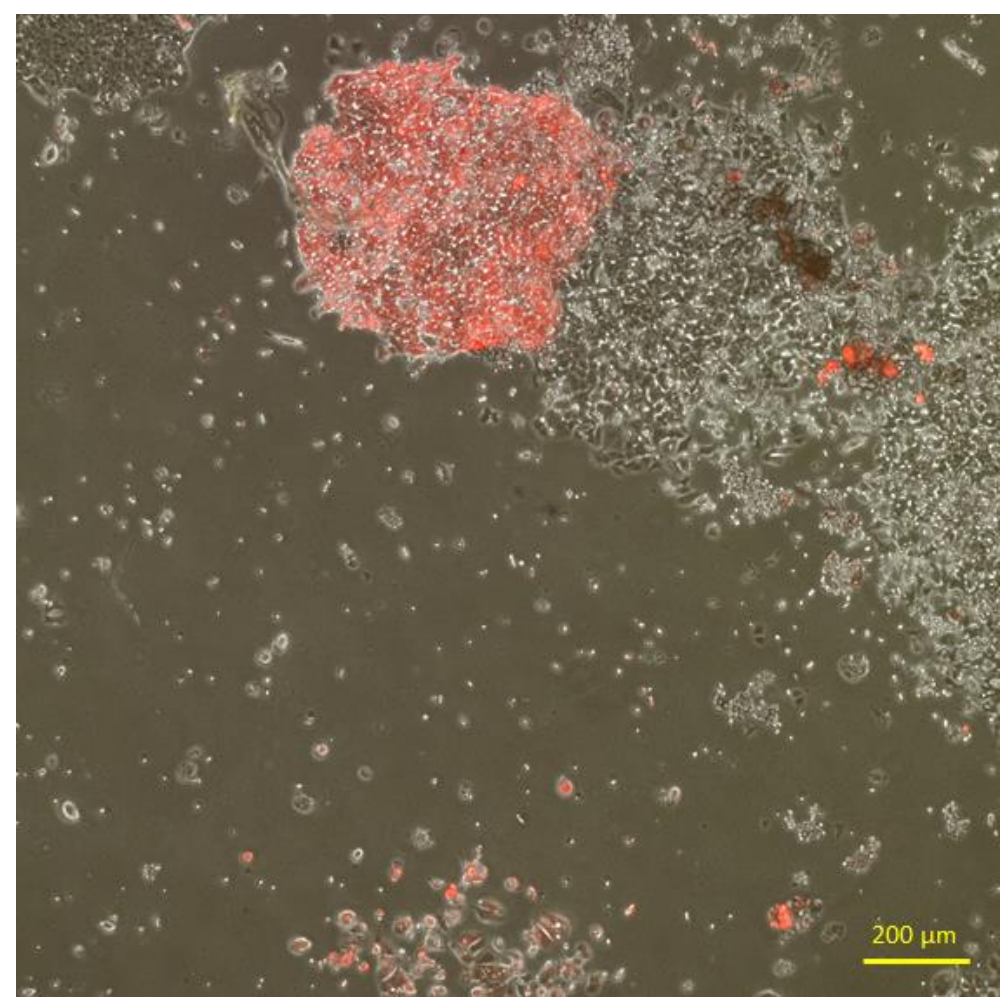

Figura 15. Microscopia ótica de fluorescência de cultura de células HCT116 após mutação gênica com sistema CRISPR-Cas9 para KO da expressão de GAL-3. Sobreposição de campos $B F+F I T C+$ TRITC; visualização em aumento de 10x. Imagem obtida 5 dias após modificação gênica. 


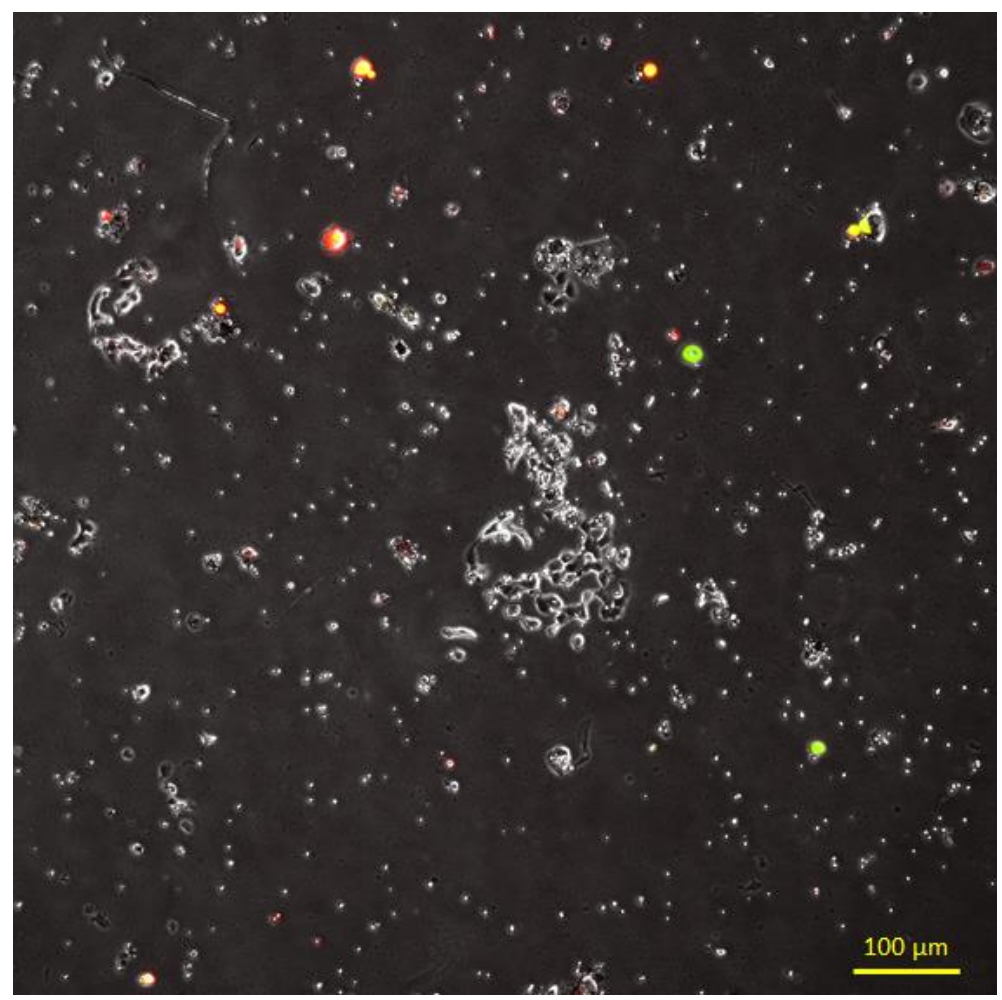

Figura 16. Microscopia ótica de fluorescência de cultura de células HCT116 após mutação gênica com sistema CRISPR-Cas9 para KO da expressão de TLR4. Sobreposição de campos $B F+F I T C+T R I T C$; visualização em aumento de 20x. Imagem obtida 7 dias após modificação gênica.

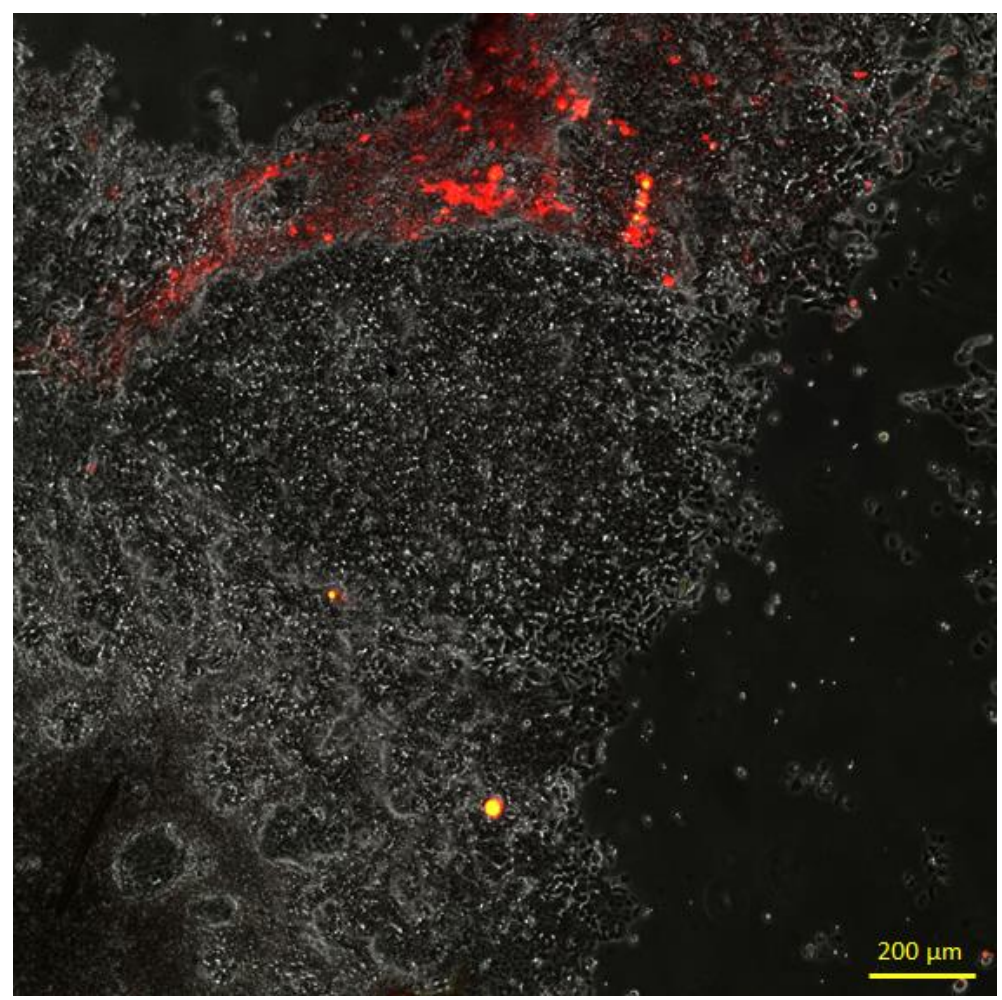

Figura 17. Microscopia ótica de fluorescência de cultura de células HCT116 após mutação gênica com sistema CRISPR-Cas9 para KO da expressão de TLR4. Sobreposição de campos $B F+F I T C+T R I T C$; visualização em aumento de 10x. Imagem obtida 14 dias após modificação gênica. 
Analisando-se as figuras 14, 16, e 17, é possível observar a emissão de fluorescência verde e vermelha em intensidades consideráveis, embora não sejam correspondentes à maioria dos clones, resultantes respectivamente da síntese de GFP e RFP, indicando que as culturas celulares assimilaram os plasmídeos utilizados para o knock-out dos genes de interesse. Em passagens celulares não submetidas à transfecção dos plasmídeos, não foram detectados sinais de fluorescência.

Conforme explorado no item 3.4.5., o sistema de plasmídeos empregado para o knock-out consistiu no uso de três grupos de plasmídeos adquiridos separadamente. O primeiro grupo de plasmídeos (CRISPR/Cas9 KO Plasmid Figura 18) consiste em uma construção plasmidial contendo a informação gênica para produção da enzima Cas9 e o gRNA de interesse, em conjunto com uma sequência gênica para a síntese de GFP, permitindo que a detecção de GFP produzida pelas células, fosse indicativo da assimilação deste plasmídeo. Além disso, considerando o fato do gene da GFP estar localizado concomitante ao gene da Cas9 e ao sistema de promotores de transcrição utilizados, a expressão da proteína fluorescente indicaria, indiretamente, que a endonuclease teria sido expressa e, portanto, o gene de interesse teria sido nocauteado através do mecanismo de quebra da fita dupla de DNA (DSB - Double Strand Break). 


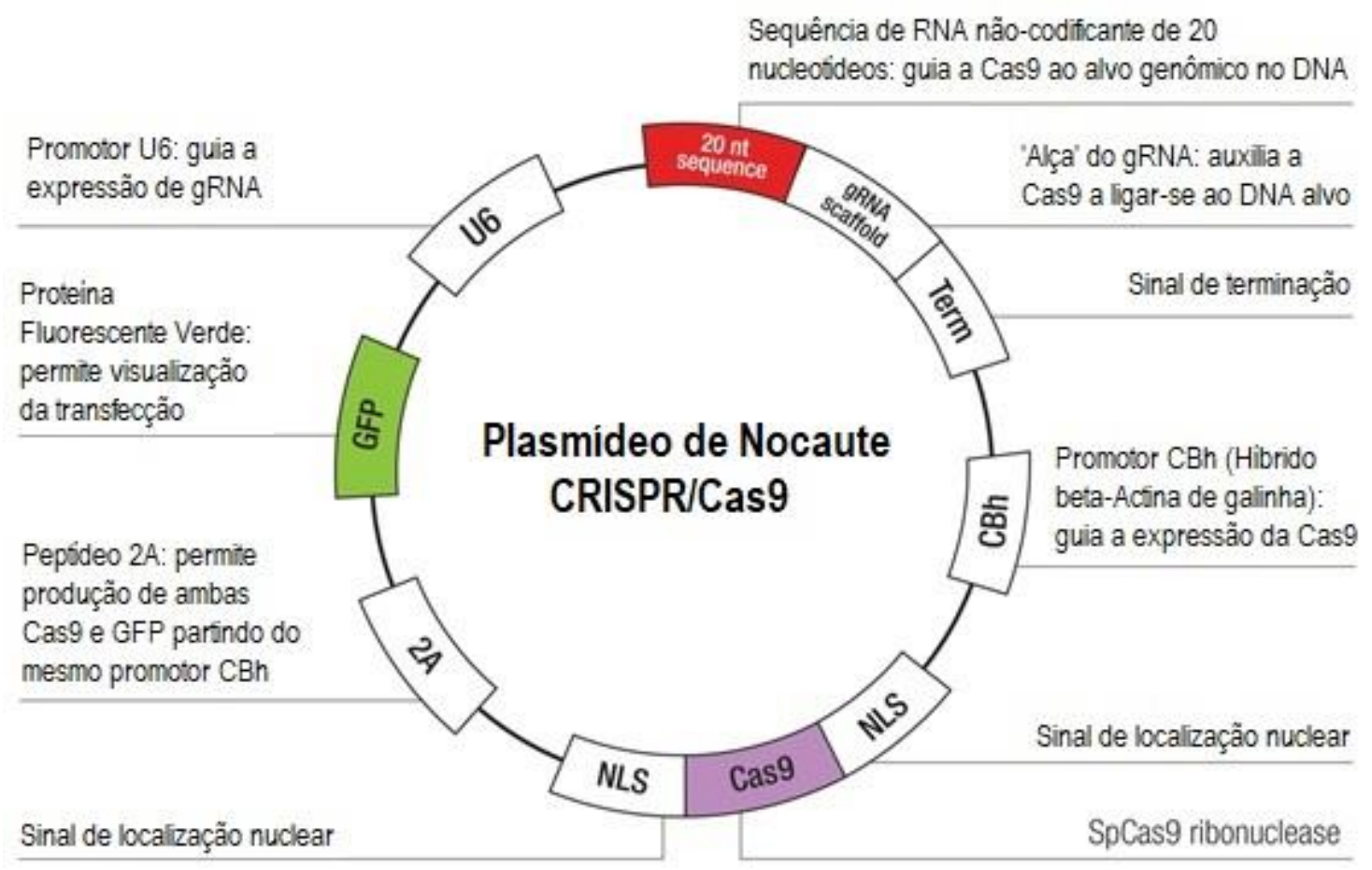

Figura 18. Representação esquemática do plasmídeo contendo gRNA + Cas9 para KO dos genes de interesse. Imagem adaptada de Santa Cruz Biotechnologies (Fonte: https://www.scbt. com/scbt/pt/product/tlr4-crispr-knockout-and-activation-products-h. Acesso em: Julho de 2016).

O segundo grupo de plasmídeos utilizado (Double Nickase Plasmid Figura 19), por sua vez, consiste em dois plasmídeos, construídos de forma que ambos permitem a inserção da informação gênica para que as células transfectadas produzam uma forma mutante da enzima Cas9, nomeada Cas9nD10A. Entretanto, um deles foi construído contendo um gene promotor de resistência ao antibiótico Puromicina, enquanto o outro contém a informação gênica para a produção de GFP pela célula. A Cas9n-D10A, diferentemente de sua forma nativa, apresenta uma modificação que faz com que a endonuclease promova a quebra de apenas uma das fitas de DNA, e não das duas fitas simultaneamente, possuindo denominação de 'nickase'. Em sistemas que visem a inserção de modificações gênicas, o emprego deste grupo de endonucleases é especialmente interessante por reduzir as chances de deleções "off-targets" (REIS, et al. 2014). No entanto, em sistemas que visem apenas a deleção de genes, como no caso deste trabalho, o emprego deste tipo de construção plasmidial em conjunto com o grupo plasmidial descrito anteriormente, aumentam as chances de sucesso do nocaute gênico. 


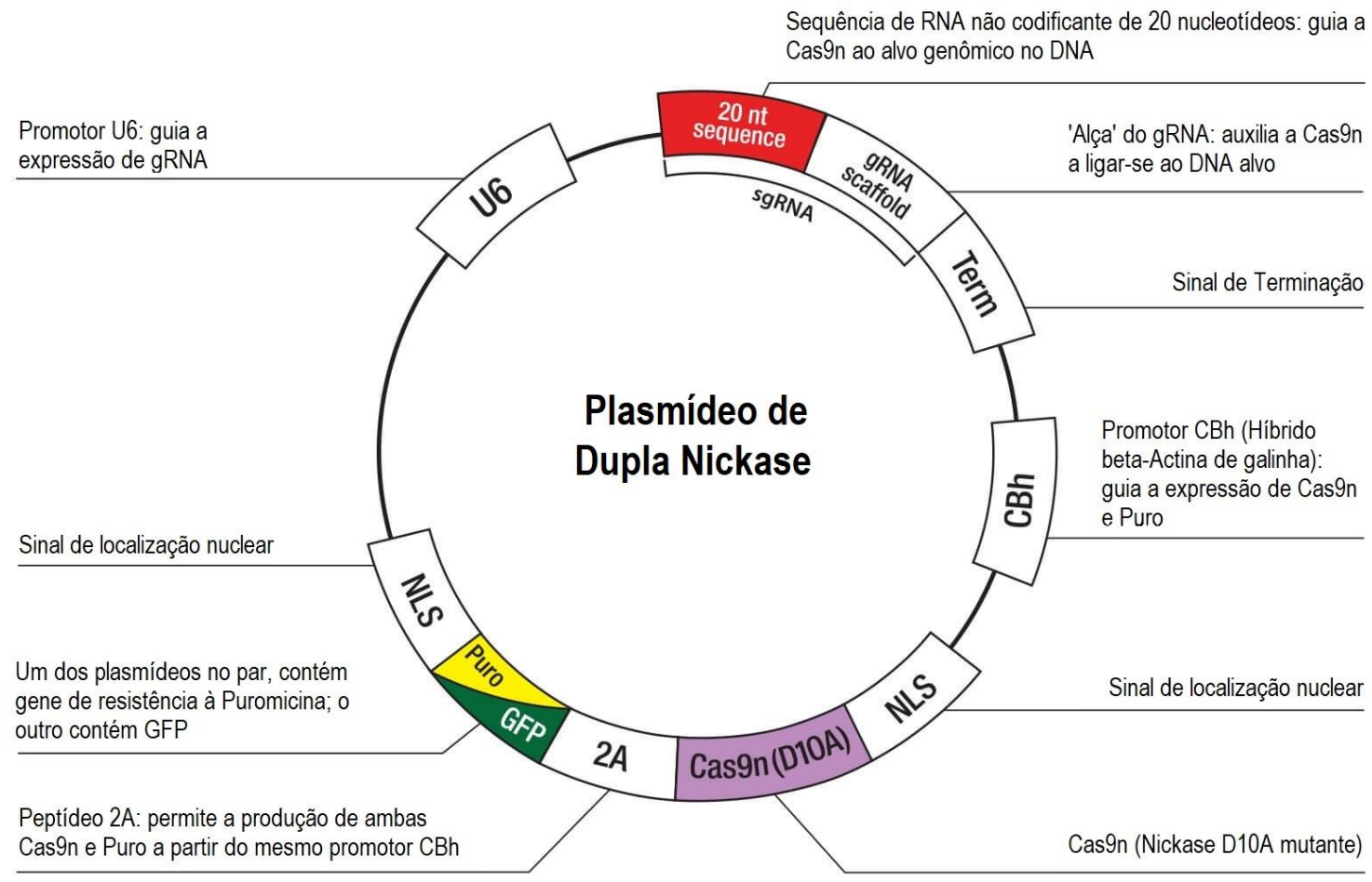

Figura 19. Representação esquemática do plasmídeo contendo gRNA + Cas9n (D10A) para auxílio do $\mathrm{KO}$ dos genes de interesse, contendo gene de resistência à Puromicina, ou para expressão de GFP acoplado. Imagem adaptada de Santa Cruz Biotechnologies (Fonte: https://datasheets.scbt.com/sc-400068-NIC.pdf. Acesso em: Julho de 2016).

Por fim, o último grupo plasmidial utilizado (HDR Plasmid - Figura 20) consiste de um plasmídeo contendo a informação gênica para a produção de RFP em conjunto com o gene para o desenvolvimento de resistência à Puromicina. Este plasmídeo foi construído a fim de ser assimilado pela célula através do mecanismo de reparo dirigido por homologia do DNA (HDR Homology Directed Repair), de tal forma que este seria incorporado ao genoma celular a partir do momento que a célula tenha sofrido a deleção genômica, passando então a expressar RFP e podendo ser selecionada com o uso da Puromicina no meio de cultura, isolando os mutantes bem-sucedidos em placa. 


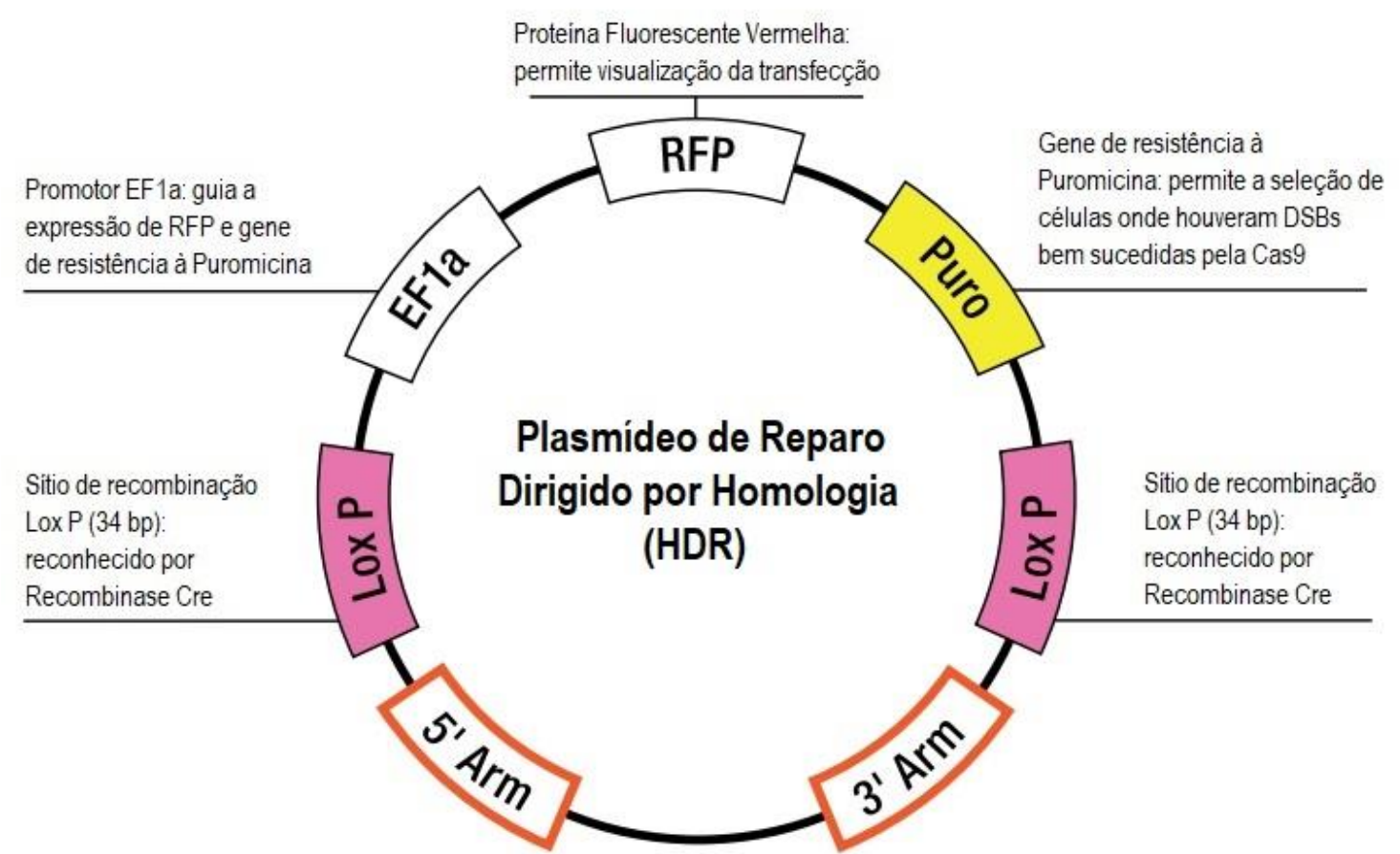

Figura 20. Representação esquemática do plasmídeo contendo gene de resistência à Puromicina e gene para a expressão de RFP acoplado. Imagem adaptada de Santa Cruz Biotechnologies (Fonte: http://datasheets.scbt.com/sc-400068-HDR.pdf. Acesso em: Julho de 2016).

Após transfecção, a seleção prévia dos clones mutantes com uso meio de cultura DMEM suplementado com Puromicina, e a constatação da assimilação dos plasmídeos através da microscopia ótica de fluorescência, foi realizado isolamento dos clones viáveis por FACS (Fluorescence Activated Cell Sorting).

O cell-sorting foi realizado com tempo máximo de uma semana após transfecção, utilizando-se das linhagens que apresentaram viabilidade celular maior que $80 \%$ para $10^{6}$ células $/ \mathrm{mL}$. Sendo assim, apenas as células submetidas ao KO da expressão de GAL-3 foram selecionadas para o procedimento, tendo em vista que as células submetidas ao KO do receptor TLR4 não apresentaram crescimento satisfatório dentro do período máximo considerado.

O FACS foi utilizado a fim de isolar as células que apresentassem fluorescência proveniente da expressão de GFP, tido que, como ilustrado anteriormente, a expressão dessa proteína estaria indiretamente relacionada à expressão da Cas9 e, portanto, as células que apresentassem fluorescência verde, seriam as mutantes com maiores chances de ter sofrido o nocaute gênico 
desejado. Os gráficos obtidos na citometria de fluxo são exibidos a seguir (Figura 21).
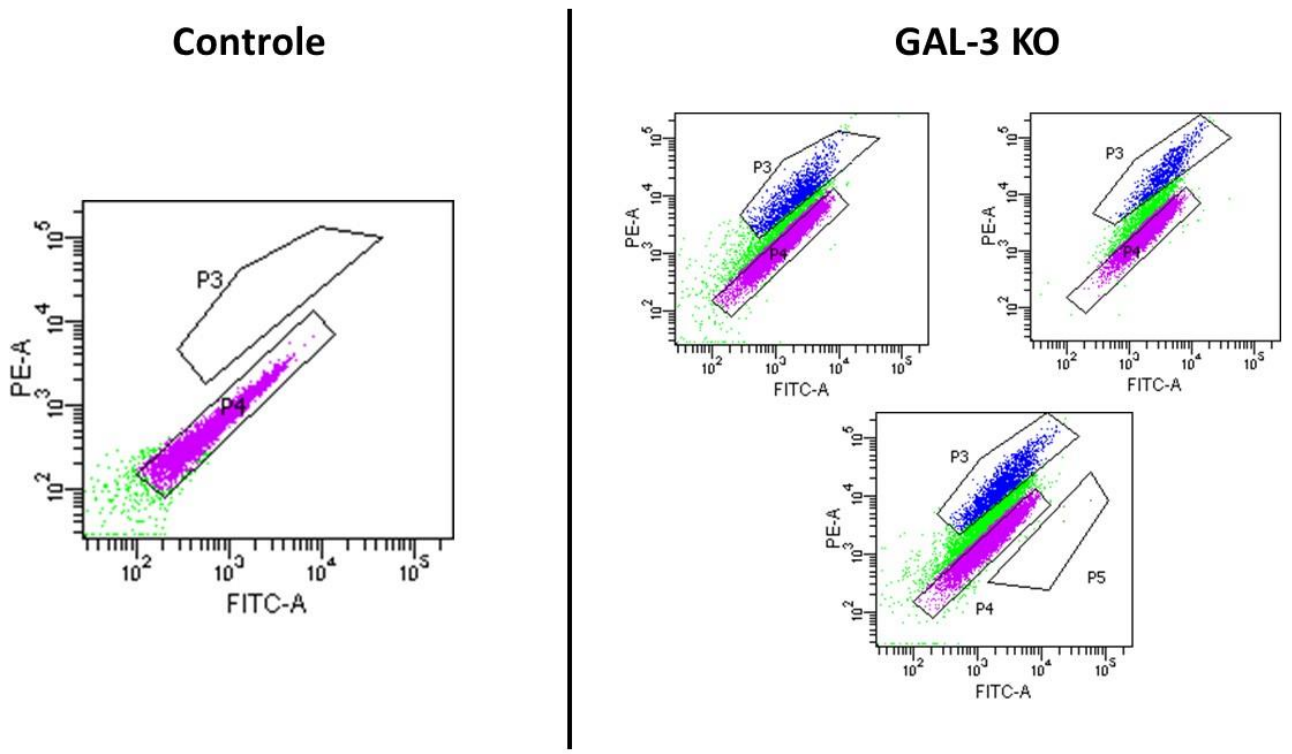

Figura 21. Gráficos correspondentes à citometria de fluxo ativada por fluorescência (FACS) do grupo Controle e dos grupos submetidos à transfecção dos plasmídeos para nocaute da expressão de GAL-3 de células HCT116. FITC-A: eixo correspondente à detecção de fluorescência verde; PE-A: eixo correspondente à detecção de fluorescência vermelha; P3: grupo correspondente aos eventos com emissão de fluorescência vermelha; P5: grupo correspondente aos eventos com emissão de fluorescência verde; P4: grupo correspondente ao controle celular, utilizado para delinear a detecção de eventos de fluorescência para os grupos P3 e P5.

Como é possível observar pelos gráficos, a linhagem submetida ao tratamento com os plasmídeos apresentou contagem de células com fluorescência correspondente ao espectro verde (eixo X - FITC-A Agrupamento P5) severamente reduzido, não sendo possível obter número satisfatório de células para isolamento em cultura, enquanto a contagem de células emitindo fluorescência vermelha (eixo Y - PE-A - Agrupamento P3) foi consideravelmente elevada. Desta forma, após a citometria de fluxo, foram obtidos dois grupos de células HCT116 submetidas ao KO da GAL-3: as células do grupo P3, que após isolamento emitiam apenas fluorescência oriunda da expressão de RFP, e o grupo de células com emissão de fluorescência majoritariamente oriunda da expressão de RFP, mas ainda com alguns focos de fluorescência proveniente da expressão de GFP. 
Considerando que a expressão de Cas9 pelas células, após incorporação dos plasmídeos, faz-se necessária apenas para a deleção do gene de interesse, uma vez que a mutação tenha sido efetuada, não é esperado que a endonuclease seja novamente produzida na próxima geração de células (DONG, et al. 2015; BÖRDING, et al. 2019). Sendo assim, embora o isolamento das células que emitissem fluorescência verde fosse de grande interesse, o resultado obtido nos gráficos de citometria expostos na Figura 21, corroboram com 0 esperado.

Novas imagens após a citometria de fluxo foram obtidas em microscopia de fluorescência, a fim de assegurar a eficiência da técnica, e são expostas a seguir.

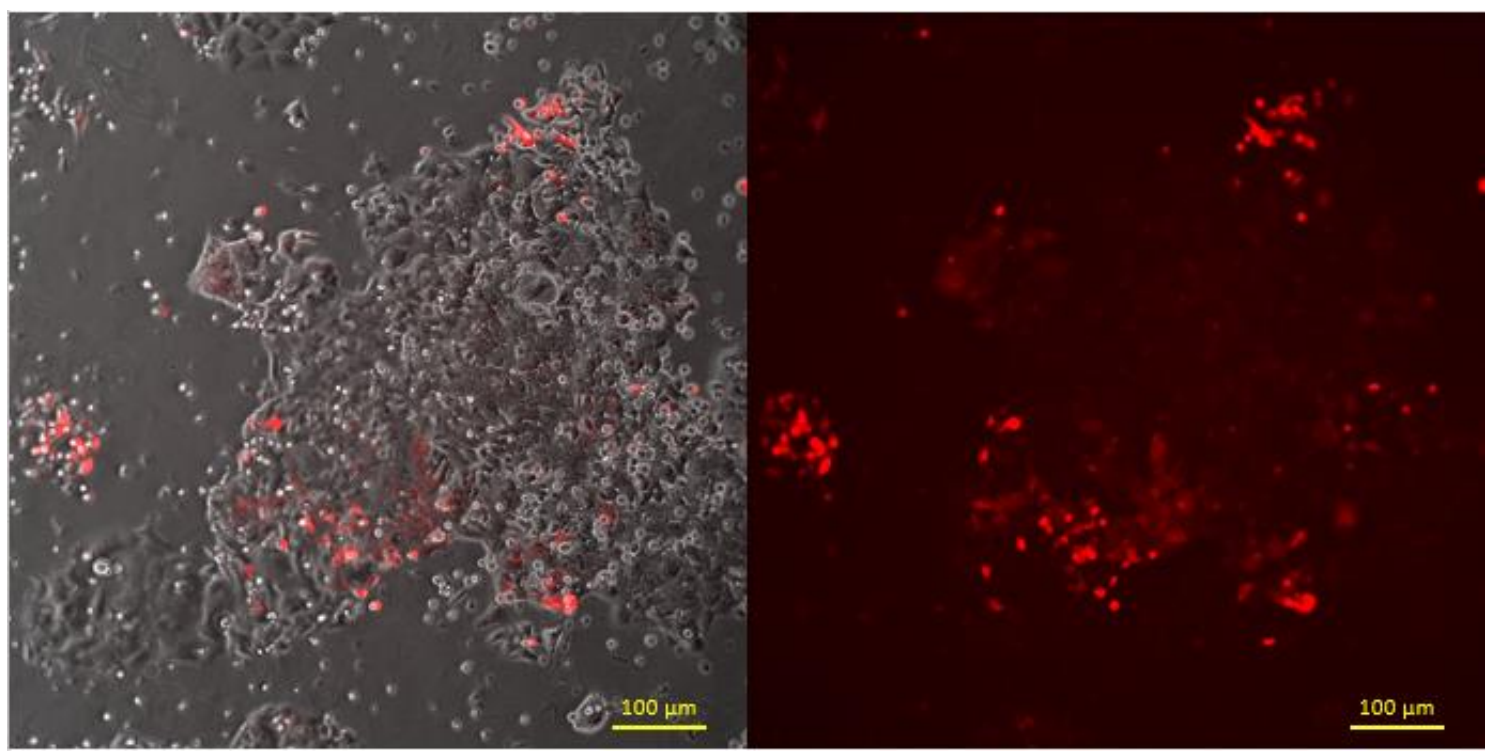

Figura 22. Microscopia ótica de fluorescência de cultura de células HCT116 após mutação gênica com sistema CRISPR-Cas9 para KO da expressão de GAL-3, submetidas a FACS. Sobreposição de campos BF + TRITC / Campo TRITC; visualização em aumento de 20x. 

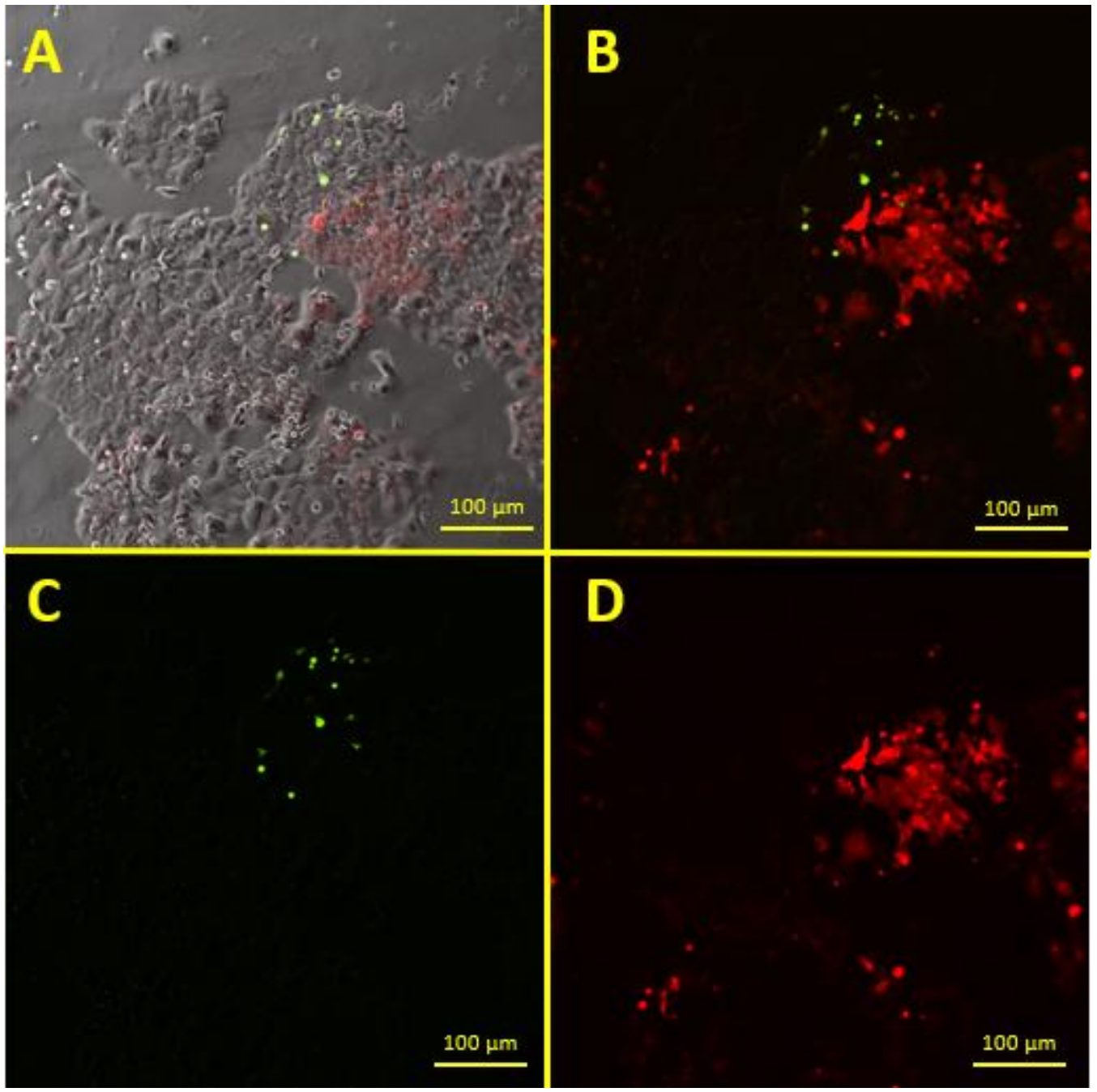

Figura 23. Microscopia ótica de fluorescência de cultura de células HCT116 após mutação gênica com sistema CRISPR-Cas9 para KO da expressão de GAL-3, recuperadas após FACS. A: Sobreposição de campos BF + FITC + TRITC; B: Campos FITC + TRITC; C: Campo FITC; D: Campo TRITC. Visualização em aumento de 20x.

As Figuras 22 e 23 permitem constatar a eficácia do FACS realizado. $\mathrm{Na}$ Figura 22, não foi detectada fluorescência oriunda da expressão de GFP, devido à seleção do grupamento P3 (Figura 21) para cultura e isolamento celular. $\mathrm{Na}$ Figura 23, por sua vez, é possível visualizar com clara distinção as fluorescências oriundas da expressão de GFP e de RFP. Nas imagens apresentadas, é possível perceber que não há sobreposição de emissão das fluorescências observadas, indicando que as culturas estariam expressando regiões diferentes de seus genes, isto é, seriam clones com padrão de expressão bem diferentes entre si. Entretanto, esses fatores não são conclusivos para a real eficácia do silenciamento dos genes por CRISPR/Cas9, demandando sua 
confirmação através de outra técnica analítica, como o ensaio de Western Blotting.

\subsection{Western Blotting}

A técnica de Western Blotting, conduzida conforme descrito em 3.4.7., foi utilizada a fim de confirmar efetivamente se o nocaute gênico das proteínas GAL3 e TLR4 foi bem-sucedido. Para tal, após determinação da quantidade de proteínas totais (Tabela 4) obtidas a partir da lise das culturas celulares selecionadas e realização do Western Blotting, foram obtidas as seguintes imagens:

Tabela 4. Determinação da quantidade total de proteínas pelo método BCA

\begin{tabular}{|c|c|c|c|c|}
\hline HCT116 Nativa & $\begin{array}{c}\text { HCT116 GAL-3 } \\
\text { KO RFP } \\
\text { isolada }\end{array}$ & $\begin{array}{c}\text { HCT116 GAL-3 } \\
\text { Ko FACS }\end{array}$ & $\begin{array}{c}\text { HCT116 TLR4 } \\
\text { KO }\end{array}$ \\
\hline Média $(\mu \mathrm{g} / \mu \mathrm{L})$ & $\mathbf{1 , 7 2}$ & $\mathbf{1 , 1 0}$ & $\mathbf{1 , 5 1}$ & $\mathbf{2 , 0 4}$ \\
\hline \multicolumn{2}{|c|}{ Regressão linear aplicada: $Y=0,001205 \mathrm{x}+0,06711 ; \mathrm{R}^{2}=0,9907$} \\
\hline
\end{tabular}

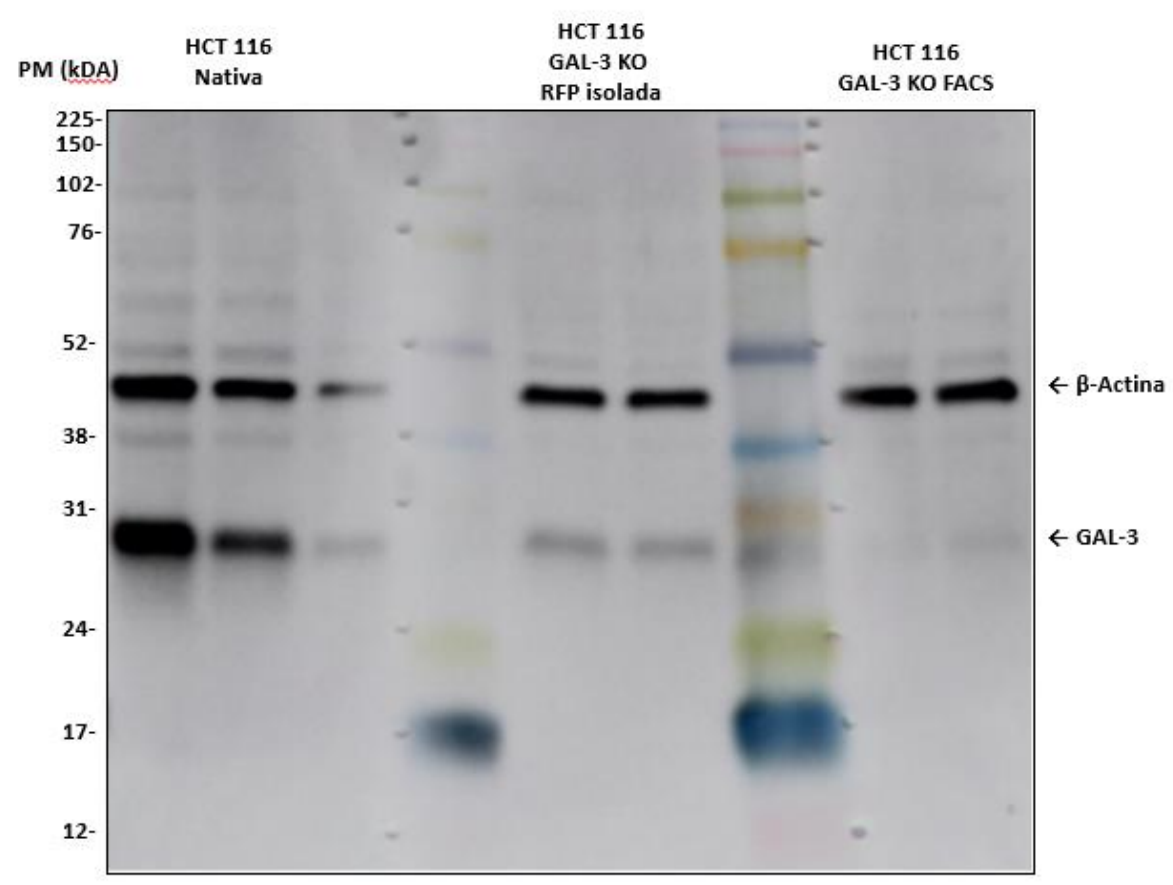

Figura 24. Western Blot das amostras de HCT116 submetidas ao tratamento visando KO da expressão de GAL-3. As bandas coloridas representam as faixas de peso molecular incluídas no padrão de pesos moleculares utilizados no teste. PM: Peso Molecular; Peso molecular da GAL3: $31 \mathrm{kDa}$. Peso molecular da $\beta$-Actina: $43 \mathrm{kDa}$. Quantidades de proteína total por banda: HCT116 = 20; 10 e $5 \mu \mathrm{g}$, respectivamente; HCT116 GAL-3 KO RFP isolada = $20 \mu \mathrm{g}$; HCT116 GAL-3 KO FACS $=20 \mu \mathrm{g}$, ambas em duplicata. 


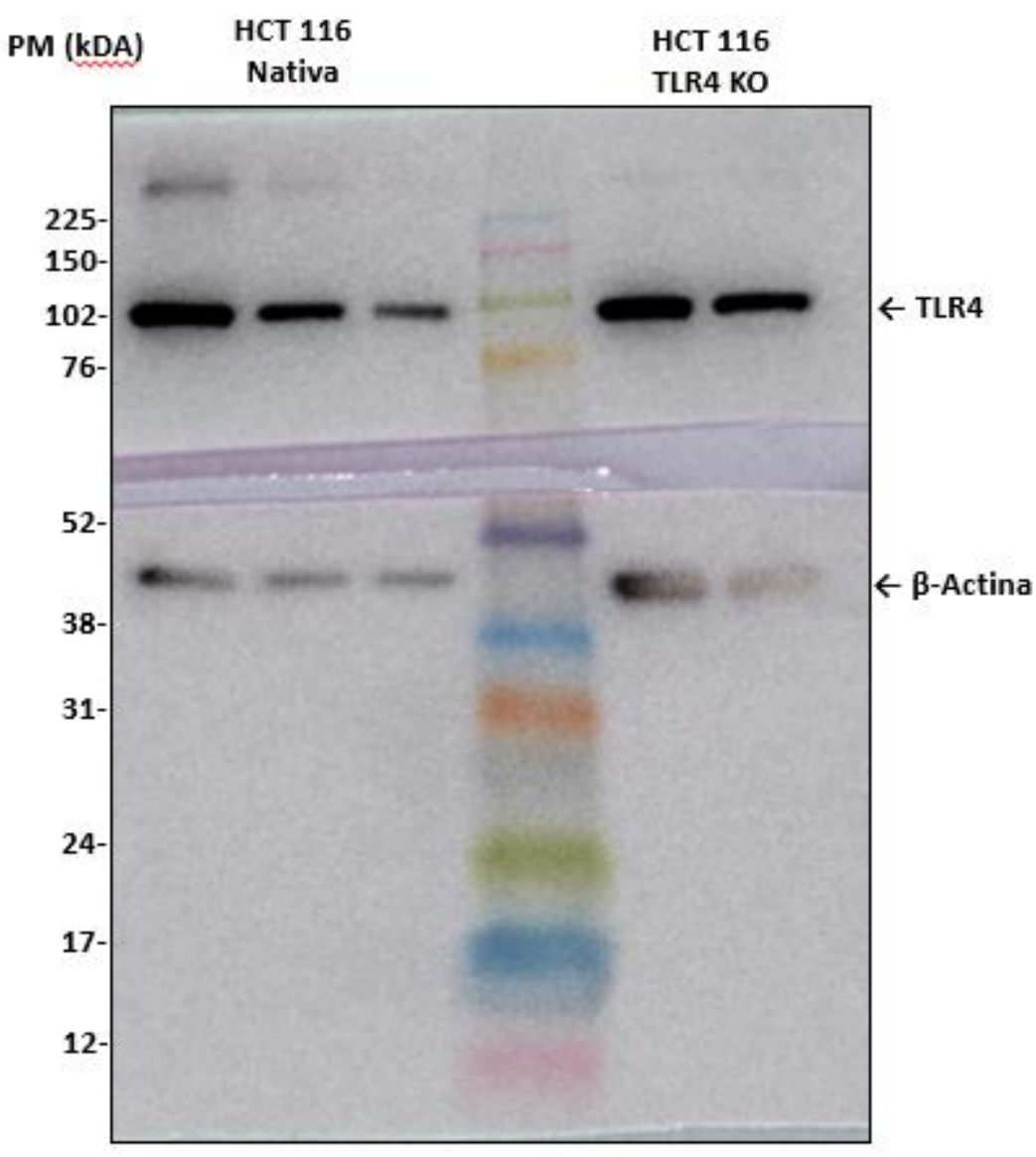

Figura 25. Western Blot das amostras de HCT116 submetidas ao tratamento visando KO da expressão de TLR4. As bandas coloridas representam as faixas de peso molecular incluídas no padrão de pesos moleculares utilizados no teste. PM: Peso Molecular; Peso molecular do TLR4: 95/120 kDa. Peso molecular da $\beta$-Actina: 43 kDa. Quantidades de proteína total por banda: HCT116 = 20; 10 e $5 \mu \mathrm{g}$, respectivamente; HCT116 TLR4 KO = $20 \mu \mathrm{g}$.

A partir da análise das figuras 24 e 25, é possível visualizar que ocorreu diminuição significativa da expressão da GAL-3 em ambas as linhagens que foram testas para a metodologia de silenciamento da expressão gênica. Entretanto, nenhuma delas silenciou completamente o gene, demonstrando que na população analisada, podem ter clones totalmente silenciados misturados aos clones não silenciados, embora os clones mutantes se apresentem em maior proporção. A linhagem representando redução significativamente expressiva da produção da referida proteína, foi aquela em que as células foram recuperadas da citometria de fluxo, ou seja, as linhagens representadas pela Figura 23.

Os resultados aqui expressos fogem do esperado, uma vez que a combinação de plasmídeos, os processos de cultivo em meio de cultura suplementado com Puromicina e a própria citometria de fluxo, deveriam favorecer a seleção das células cuja aplicação da técnica CRISPR/Cas9 tenha 
sido bem-sucedida. Neste contexto, faz-se necessário destacar que culturas de células HCT116 nativas foram cultivadas sob as mesmas condições que as células que foram submetidas ao processo de transfecção, de tal forma que, quando em contato com a Puromicina, não foram capazes de sobreviver por mais que 5 dias, além de não apresentarem qualquer tipo de fluorescência quando analisadas em microscopia ótica de fluorescência (dados não apresentados). Esta informação, em conjunto com a constatação de fluorescência (como observado nas figuras 16, 17 e 22), demonstram que, embora o silenciamento gênico completo que deveria ser promovido pela Cas9 não tenha sido bem-sucedido, as células foram capazes de assimilar os plasmídeos utilizados, e então expressar os genes introduzidos para produção de RFP, GFP e de resistência à Puromicina, indicando que os procedimentos de transfecção dos plasmídeos e, até certo ponto, da modificação genômica das células, foi bem-sucedido.

Neste contexto, duas soluções são cogitadas para refinamento da técnica em aplicações futuras no laboratório do departamento, visando unicamente o nocaute gênico:

A primeira delas, sugere que os plasmídeos utilizados sejam mantidos, e após transfecção destes, que as células sejam submetidas à citometria de fluxo tão logo possível para isolamento e cultivo dos clones que estejam expressando GFP nos primeiros dias após a transfecção, de preferência em concomitância com a primeira troca de meio a ser realizada após o procedimento. Desta forma, é esperado que estes clones isolados tenham expressado a Cas9 e estariam então aptos a crescer em um ambiente livre de competição com clones não mutantes.

A segunda solução, consistiria no uso de construções plasmidiais que contivessem a informação gênica para a síntese da endonuclease Cas9, do gRNA para a região alvo do DNA, de GFP ou RFP e do gene de resistência à algum antibiótico, como a Puromicina. Desta forma, ao submeter as células à cultura com meio suplementado com o antibiótico, apenas as células que tenham assimilado os plasmídeos seriam capazes de sobreviver, desta forma, havendo garantia de que estes clones sofreram a modificação gênica desejada. 
Independentemente do exposto, para prosseguimento dos experimentos, foi selecionada a cultura de células cuja expressão de GAL-3 foi diminuída com maior intensidade, conforme exposto na Figura 24.

\subsection{Tratamentos da linhagem HCT116 GAL-3 KO com diferentes pectinas} de mamão.

Conforme descrito em 3.4.8., submeter a linhagem nocauteada para a expressão de GAL-3 a tratamentos com pectinas com diferentes características, oriundas das suas formas de obtenção e dos tempos de maturação diferenciados, permite traçar um panorama de atividade desses polissacarídeos quanto à capacidade de afetar a atividade metabólica de células tumorais, in vitro, em um ambiente onde a GAL-3 tenha sido efetivamente removida.

Os resultados obtidos a partir do tratamento com as amostras utilizadas para os tratamentos com inibição química (item 4.6), representados na Figura 26, permitem observar que as células modificadas para a expressão de GAL-3 foram capazes de manter sua atividade metabólica ao longo de 3 dias de tratamento, sugerindo que, para esta amostra de pectinas, a inibição biológica da expressão de GAL-3 foi capaz de promover 'proteção' das culturas celulares com relação aos efeitos das pectinas, resultado esse que contradiz a inibição química da GAL-3. 


\section{HCT116 GAL-3 KO}

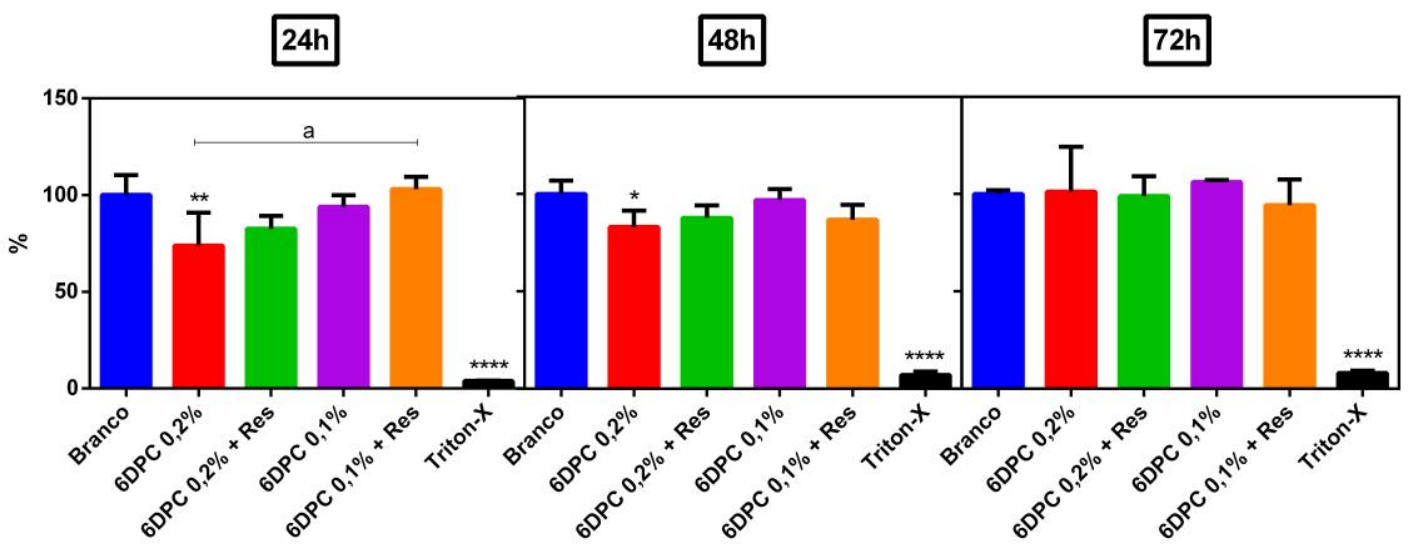

Figura 26. Gráficos de viabilidade celular (em porcentagem) da linhagem HCT116 GAL-3 KO representados como barras para cada tratamento, em cada período de tempo considerado. Os asteriscos representam, em ordem crescente de relevância, a diferença estatística obtida entre os dados comparados com o branco experimental, de acordo com teste de Dunnett ${ }^{*}-p \leq 0,05$; $\left.{ }^{* *}-p \leq 0,01 ;{ }^{* * *}-p \leq 0,001 ;{ }^{* * * *}-p \leq 0,0001 ; n=4\right)$. As letras representam, em ordem crescente de relevância, a diferença estatística obtida da comparação entre os grupos de dados considerados, de acordo com teste de Tukey, onde cada marcação presente na barra horizontal imediatamente abaixo da letra representa a comparação entre o grupo de dados considerado no início da barra, com o grupo de dados indicado pela marcação $(a-p \leq 0,05 ; b-p \leq 0,01 ; c-p \leq$ $0,001 ; d-p \leq 0,0001 ; n=9)$. 6DPC: Fração Solúvel em Água de amostras com estágio de maturação de 6 dias pós-colheita; Res: Resatorvid.

Isso pode ter ocorrido pois a inibição química é pontual, com poucas chances das células se adaptarem através de alteração da expressão gênica. Por outro lado, a inibição biológica por silenciamento gênico aumenta as chances das células se adaptarem a essa disfuncionalidade forçada e duradoura, fazendo com que a célula de adapte para continuar com o perfil agressivo de crescimento acelerado. A Figura 12 poderia corroborar essa hipótese, pois exibe que a amostra, quando isolada, é capaz de promover queda acentuada e duradoura da viabilidade de células HCT116 (T1). Quando em cenário de inibição química (T2), a amostra teria acentuado seus efeitos de promoção de queda da atividade metabólica e da população celular. Entretanto, a inibição química concomitante da GAL-3 e de TLR4 (T4) fez com que a viabilidade fosse maior do que apenas a inibição química da GAL-3, indicando que, apesar dos resultados de maior atividade metabólica das células silenciadas e a diminuição dos efeitos das pectinas da amostra 6DPC, a inibição química do TLR4 pode ter auxiliado na diminuição dos efeitos do tratamento com as pectinas. 
A Figura 27 ilustra que, ao longo do tempo, a amostra 4FSA [0,1\% p/V] + Res $[1,0 \mu \mathrm{M}]$ foi a que apresentou maior capacidade de comprometer a viabilidade celular, com relação ao grupo Branco.

\section{HCT116 GAL-3 KO}

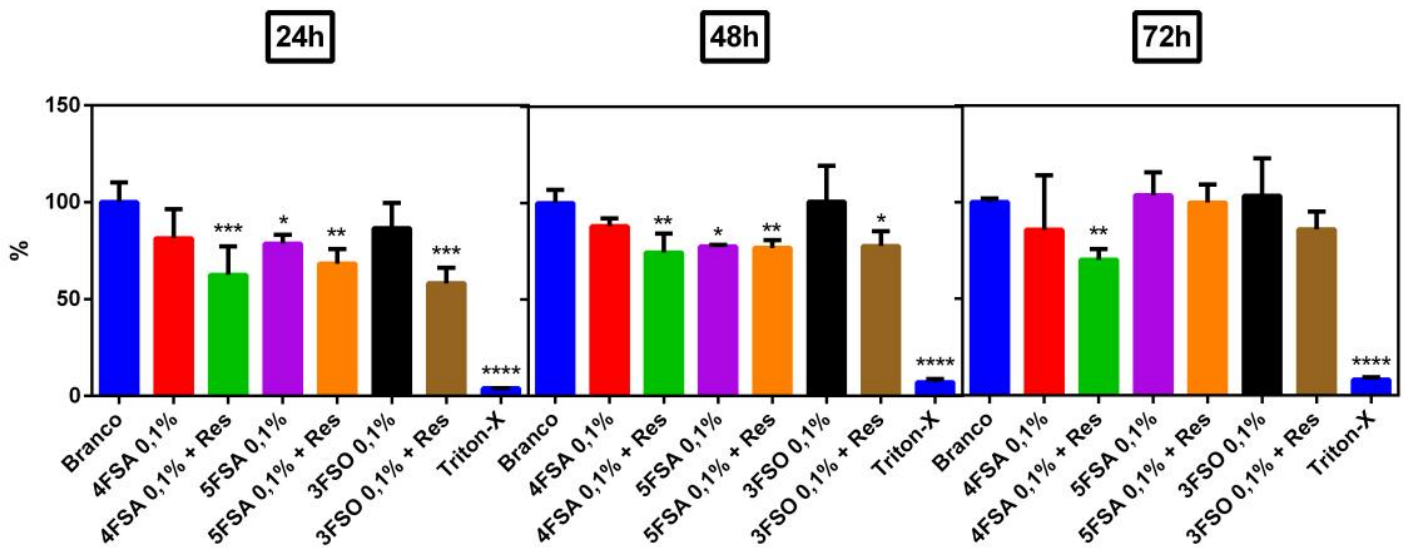

Figura 27. Gráficos de viabilidade celular (em porcentagem) da linhagem HCT116 GAL-3 KO representados como barras para cada tratamento, em cada período de tempo considerado. Os asteriscos representam, em ordem crescente de relevância, a diferença estatística obtida entre os dados comparados com o branco experimental, de acordo com teste de Dunnett ( ${ }^{*}-p \leq 0,05$; $\left.{ }^{* *}-p \leq 0,01 ;{ }^{* * *}-p \leq 0,001 ;{ }^{* * *}-p \leq 0,0001 ; n=4\right)$. As letras representam, em ordem crescente de relevância, a diferença estatística obtida da comparação entre os grupos de dados considerados, de acordo com teste de Tukey, onde cada marcação presente na barra horizontal imediatamente abaixo da letra representa a comparação entre o grupo de dados considerado no início da barra, com o grupo de dados indicado pela marcação $(a-p \leq 0,05 ; b-p \leq 0,01 ; c-p \leq$ $0,001 ; d-p \leq 0,0001 ; n=9)$. 4FSA e 5FSA: Fração Solúvel em Água de amostras com estágio de maturação de 4 e 5 dias pós-colheita, respectivamente; 3FSO: Fração Solúvel em Oxalato de amostras com estágio de maturação de 3 dias pós-colheita; Res: Resatorvid.

Explorando diferentes amostras de pectinas de mamões, vale a comparação com a amostra caracterizada no atual trabalho. A amostra 6 DPC, conforme explorado na Figura 26, não foi capaz de produzir impacto significativo no metabolismo celular geral da células ao longo do período de tratamento, e que essa amostra apresenta cadeias de aproximadamente 102,16 kDa e 6,64 kDa. Já a observação de que a amostra 4FSA (com pesos moleculares mais elevados (PRADO, et al. 2016)) foi capaz de reduzir a atividade metabólica das células nocauteadas para a expressão de GAL-3, em um cenário onde o uso de Resatorvid se fez importante, sugere que as pectinas com pesos moleculares mais elevados sejam capazes de ativar outras vias que dificultem a manutenção dos processos metabólicos normais das células tumorais, sem dependência da 
interação com GAL-3, tampouco da possível estimulação do receptor TLR4, cuja inibição química auxiliou na redução da viabilidade, ao contrário do observado para a amostra 6DPC (Figuras 12 e 26). Em outras palavras, os dados expostos evidenciam que a redução das taxas metabólicas de células de câncer colorretal por ação de pectinas de mamão, in vitro, pode também se dar por vias independentes da interação com a GAL-3 e também por vias de estimulação ou inibição dos receptores TLR4, havendo correlação com o peso molecular do polissacarídeo em questão.

O conflito originado entre os dados obtidos pelos testes descritos em 4.6.2. e em 4.9., com relação à amostra 6DPC, demonstram a complexidade das possíveis interações bioquímicas que venham a ocorrer nas células nos cenários avaliados, especialmente considerando a possibilidade de alterações metabólicas oriundas de adaptação das células em resposta ao desligamento gênico (NEWLACZYL e YU, 2011), bem como de mutações off-target que possam ter sido originadas a partir da mutação induzida por CRISPR-Cas9 e que não são incomuns (ZHANG, et al. 2015; WIENERT, et al. 2019).

A Figura 28, ilustrada a seguir, explicita que as amostras com menores pesos moleculares dentre os grupos considerados, promoveram os resultados com maior relevância estatística. 


\section{HCT116 GAL-3 KO}

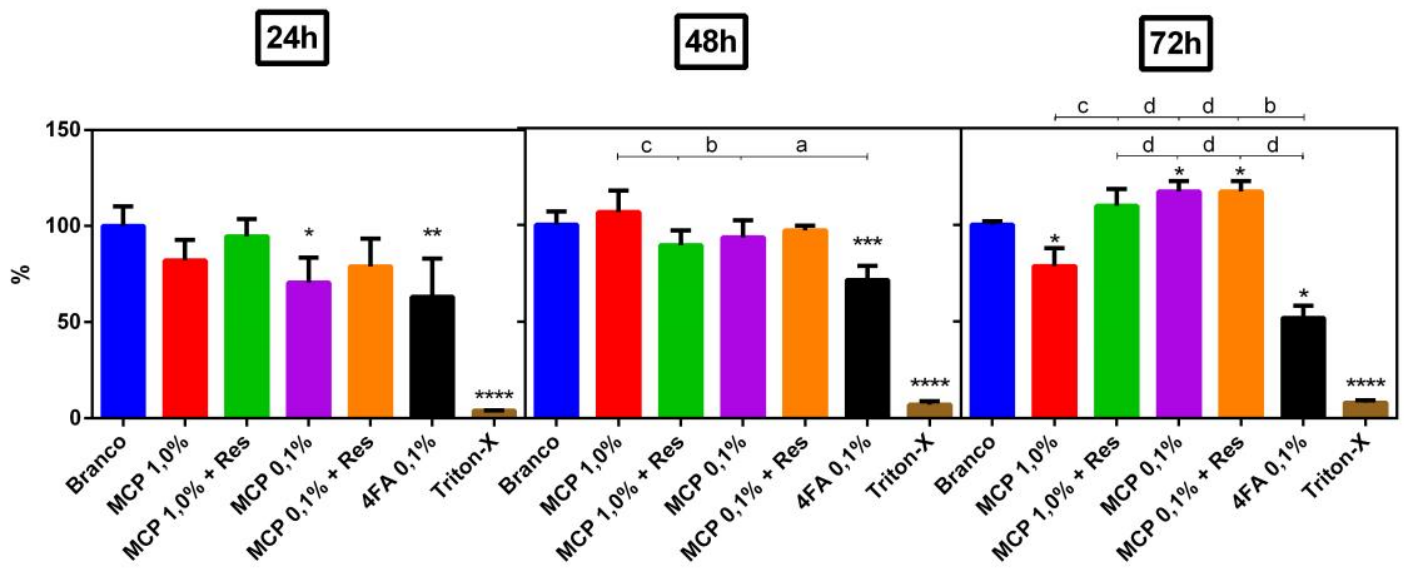

Figura 28. Gráficos de viabilidade celular (em porcentagem) da linhagem HCT116 GAL-3 KO representados como barras para cada tratamento, em cada período de tempo considerado. Os asteriscos representam, em ordem crescente de relevância, a diferença estatística obtida entre os dados comparados com o branco experimental, de acordo com teste de Dunnett ${ }^{*}-p \leq 0,05$; $\left.{ }^{* *}-p \leq 0,01 ;{ }^{* * *}-p \leq 0,001 ;{ }^{* * * *}-p \leq 0,0001 ; n=4\right)$. As letras representam, em ordem crescente de relevância, a diferença estatística obtida da comparação entre os grupos de dados considerados, de acordo com teste de Tukey, onde cada marcação presente na barra horizontal imediatamente abaixo da letra representa a comparação entre o grupo de dados considerado no início da barra, com o grupo de dados indicado pela marcação $(a-p \leq 0,05 ; b-p \leq 0,01 ; c-p \leq$ 0,001; $d-p \leq 0,0001 ; n=9$ ). MCP: Pectina de Citros Modificada; 4FA: Fração Ácida com estágio de maturação de 4 dias pós-colheita; Res: Resatorvid.

A amostra MCP utilizada no estudo apresenta peso molecular de $35 \mathrm{kDa}$ (PRADO, et al. 2019b), e no período de 72h de estudo, foi capaz de manter, isoladamente, queda na atividade metabólica das células nocauteadas para a expressão de GAL-3, de tal forma que, quando na presença de Resatorvid, este efeito deixa de ser tão pronunciado, assim como observado com a amostra 6DPC. Esse fato sugere que para ocorrer efeito redutor da viabilidade das células pela ação dessas pectinas, a interação através do receptor TLR4 possua alguma forma de atuação representativa.

Outro dado digno de destaque é o comportamento observado nas células quando tratadas com a amostra de 4FA, tratamento este que produziu o maior e mais duradouro impacto entre os grupos testados. Neste contexto, é necessário pontuar que todas as amostras testadas, em alguma intensidade, apresentavam capacidade interativa com a Galectina-3 (dados não expostos), com exceção da amostra 6DPC. Ao observar a queda de viabilidade produzida pela amostra 4FA, em grupo celular cuja expressão de GAL-3 foi nocauteada, é possível afirmar que sua atuação se dá por algum mecanismo independente da presença de GAL-3, e quando em comparação com os demais grupos, a combinação variada 
de tamanhos moleculares dos polissacarídeos presentes na amostra poderiam também ter papel fundamental no efeito observado, de forma que o efeito pode ter se manifestado por mais de uma via independente de Galectina-3. Infelizmente, devido à restrição da quantidade de amostra 4FA, não foi possível efetuar o tratamento com a inibição do TLR4.

\section{Considerações finais}

De acordo com os dados expostos, o amadurecimento natural do fruto produziu cadeias de polissacarídeos com tamanhos de aproximadamente 102 kDa e 6 kDa, valores aproximados aos apresentados pelo fruto com 3 e 4 dias de amadurecimento após a colheita. Isto se deve ao fato de ocorrer a migração de polissacarídeos pertencentes nas frações insolúveis em água para as frações de maior solubilidade em água devido à ação de pectinases endógenas estimuladas ao longo do amadurecimento, justificando assim os pesos moleculares encontrados.

Quanto à atividade biológica, pode-se inferir que a fração solúvel em água da pectina extraída da polpa de mamão papaia com 6 dias de amadurecimento após a colheita apresenta atividade, in vitro, sobre o metabolismo celular de linhagens de células de câncer colorretal, diminuindo a viabilidade destas com mecanismos dose-dependentes, e que a associação com N-Acetil-Lactosamina potencializa o efeito destes polissacarídeos. Neste contexto, é importante destacar que outros pesquisadores do grupo realizaram experimentos buscando visualizar a capacidade de inibição da GAL-3 pela FSA da amostra de mamão papaia extraída ao longo deste trabalho, e verificaram através de teste de hemaglutinação que a amostra não foi capaz de inibir a referida proteína. Estes dados, em conjunto com as observações produzidas após tratamento com células nocauteadas para a expressão de GAL-3, indicam que provavelmente a ação da FSA da amostra 6DPC se dá por alguma via que possa estar evidenciada quando a GAL-3 está inibida. Além disso, os demais dados apresentados ao longo do texto permitem supor que, provavelmente, a necroptose descrita em PRADO et al., 2017, pode ter se dado por estimulação de receptores TLRs.

Ao avaliar o comportamento das células submetidas ao nocaute gênico da GAL-3 com amostras de pectinas com características próprias, oriundas de 
suas formas de extração e do tempo de amadurecimento dos frutos a partir das quais foram extraídas, é possível perceber que, embora a interação com a GAL3 pareça exercer papel fundamental para a promoção de efeito supressor da atividade metabólica das células tumorais, outras vias metabólicas podem também ser acionadas a depender de caracteres como peso molecular das amostras, reforçando os eventos descritos em PRADO, et al. 2017.

\section{Conclusão}

Os dados coletados ao longo do projeto, em conjunto com informações oriundas dos demais projetos do departamento, permitem constatar que a via biológica pela qual as pectinas de mamão papaia impactam negativamente na capacidade metabólica de células tumorais de câncer colorretal, in vitro, pode estar correlacionada com o peso molecular da fibra em questão, de tal forma que seus efeitos podem envolver, mas não se limitando, a interação com a GAL-3.

\section{Bibliografia}

AMERICAN CANCER SOCIETY. Global Cancer Facts \& Figures 3rd Edition. Atlanta: American Cancer Society; 2015.

AMITAI, G; SOREK, R. CRISPR-Cas adaptation: insights into the mechanism of action. Nature Reviews - Microbiology. Fevereiro de 2016, v.14.

BÖRDING, T; ABDO, A. N; MAIER, B; GABRIEL, C; KRAMER, A. Generation of Human CRY1 and CRY2 Knockout Cells Using Duplex CRISPR/Cas9 Technology. Frontiers in Physiology. Maio de 2019.

BRATTAIN, M. G; FINE, W. D; KHALED, F. M; THOMPSON, J; BRATTAIN, D. E. Heterogeneity of Malignant Cells from a Human Colonic Carcinoma. Cancer research, Maio de 1981, v. 41 , p. $1751-1756$.

BRAY, F; FERLAY, J; SOERJOMATARAM, I; SIEGEL, R. L; TORRE, L. A; JEMAL, A; Global Cancer Statistics 2018: GLOBOCAN Estimates of Incidence and Mortality Worldwide for 36 Cancers in 185 Countries. CA Cancer J Clin 2018, Nov; 68:394-424

BRUCE, W. R; GIACCA, A; MEDLINE, A. Possible Mechanisms Relating Diet and Risk of Colon Cancer. Cancer Epidemiology, Biomarkers \& Prevention, Dezembro de 2000, vol. 9, p. $1271-1279$.

BODE, A. M; DONG, Z. Cancer Prevention Research-Then and Now. Nat. Rev. Cancer, Julho de 2009, 9(7), p. 508-516.

CANCER STATISTICS CENTER. Colorectum at a glance. 2015. Disponível em:

<https://cancerstatisticscenter.cancer.org/?_ga=1.111042245.1774109092.1456442227\#/cance r-site/Colorectum>. Acesso em: 03 de junho de 2016. 
CARDOSO, A. C. F; ANDRADE, L. N. de S; BUSTOS, S. O; CHAMMAS, R. Galectin-3 determines tumor cell adaptive strategies in stressed tumor microenvironments. Frontiers in Oncology, 23 de Maio de 2016, vol. 6, 127.

CARIO, E; ROSENBERG, I. M; BRANDWEIN, S. L; BECK, P. L; REINECKER, H-C; PODOLSKY, D. K. Lypopolysaccharide Activates Distinct Signaling Pathways in Intestinal Epithelial Cell Lines Expressing Toll-Like Receptors. The Journal of Imunology, 2000, v. 164, p. 966-972.

CARRINGTON, C. M; GREVE, L. C; LABAVITCH, J. M. Cell Wall Metabolism in Ripening Fruit. Effect of the Antisense Polygalacturonase Gene on Cell Wall Changes Accompanying Ripening in Transgenic Tomatoes. Plant Physiol. vol. 103, 1993, p. 429-434.

CHRISTENSEN, J; EL-GEBALI, S; NATOLI, M; SENGSTAG, T; DELORENZI, M; BENTZ, S; BOUZOURENE, H; RUMBO, M; FELSANI, A; SIISSALO, S; HIRVONEN, J; VILA, M. R; SALETTI, P; AGUET, M; ANDERLE, P. Defining new criteria for selection of cell-based intestinal models using publicly available databases. BMC Genomics, 2012, $13: 274$

DONG, S; LIN, J; HELD, N. L; CLEM, R. J; PASSARELLI, A. L; FRANZ, A. W. E. Heritable CRISPR/Cas9-Mediated Genome Editing in the Yellow Fever Mosquito, Aedes aegypti. PLoS One. 2015; 10(3).

FABI, J. P; BROETTO, S. G; SILVA, S. L. G. L. da; ZHONG, S; LAJOLO, F. M; NASCIMENTO, J. R. O. do. Analysis of Papaya Cell Wall-Related Genes during Fruit Ripening Indicates a Central Role of Polygalacturonases during Pulp Softening. PLOS ONE, Agosto de 2014, v. 9, edição 8.

FÁVARO, W. J; NUNES, O. S; SELVA, F. R. F; NUNES, I. S; WOOLHISER, L. K; DURÁN, N; LENAERTS, A. J. Effects of P-MAPA Immunomodulator on Toll-Like Receptors and p53: Potential Therapeutic Strategies for Infectious Diseases and Cancer. Infectious Agents and Cancer 2012, p. 7-14

FLEMING, M; RAVULA, S; TATISHCHEV, S. F; WANG, H. L. Colorectal carcinoma: Pathological aspects. Gastrointestinal oncology, 2012; 3 (3), 153-173.

GAO, X; ZHI, Y; SUN, L; PENG, X; ZHANG, T; XUE, H; TAI, G; ZHOU, Y. The Inhibitory Effects of a Rhamnogalacturonan I (RG-I) Domain from Ginseng Pectin on Galectin-3 and Its Structure-Activity Relationship. The Journal of Biological Chemistry Vol. 288, NO. 47, p. 33953-33965, November 22, 2013.

GATOF, D; AHNEN, D. Primary prevention of colorectal cancer: diet and drugs. Gastroenterology clinics of north America. 2002, vol. 31, p. 587 - 623.

GLINSKY, V. V; RAZ, A. Modified citrus pectin anti-metastatic properties: one bullet, multiple targets. Carbohydrate Research. 2009 September 28; 344(14): 1788-1791

GUTIÉRREZ-GRIJALVA, E. P; AMBRIZ-PÉRE, D. L; LEYVA-LÓPES, N; CASTILLO-LÓPEZ, R. I; HEREDIA, J. B. Dietary phenolic compounds, health benefits and bioaccessibility. Archivos latinoamericanos de nutrición, 2016, vol. 66, no 2, p. 87 - 100.

HARHOLT, J; SUTTANGKAKUL, A; SCHELLER, H. V. Biosynthesis of Pectin. Plant Physiol. Vol. 153, 2010

HAO, M; YUAN, X; CHENG H; XUE H; ZHANG, T; ZHOU, Y; TAI, G. Comparative studies on the anti-tumor activities of high temperature- and $\mathrm{Ph}$-modified citrus pectins. Food Funct., 2013, 4, p. 960-971.

HEKMATI, M; POLAK-CHARCON, S; BEM-SHAUL, Y. A morphological study of a human adenocarcinoma cell line (HT29) differentiating in culture. Similarities to intestinal embryonic development. Cell Differentiation and Development. 1990, vol. 31, p. $207-218$. 
HOUBEN, K; JOLIE, R. P; FRAEYE, I; van LOEY, A. M; \& HENDRICKX, M. E; Comparative study of the cell wall composition of broccoli, carrot, and tomato: Structural characterization of the extractable pectins and hemicelluloses. Carbohydrate Research, 2011. 346(9), 1105-1111.

INCA - INSTITUTO NACIONAL DE CÂNCER JOSÉ ALENCAR GOMES DA SILVA. ESTIMATIVA 2018 - Incidência de câncer no Brasil. 2018. Disponível em: $<$ https://www.inca.gov.br/sites/ufu.sti.inca.local/files//media/document//estimativa-incidencia-decancer-no-brasil-2018.pdf>. Acesso em: 10 de março de 2019.

IRWIN, D. C; CHENG, M; XIANG, B; ROSE, J. K. C; WILSON, D. B. Cloning, expression and characterization of a family-74 xyloglucanase from Thermobifida fusca. Eur. J. Biochem. Vol. 270, 2003, p. 3083-3091.

JACKSON, C. L; DREADEN, T. M; THEOBALD, L. K; TRAN, N. M; BEAL, T. L; EID, M; GAO, M. Y; SHIRLEY, R. B; STOFFEL, M. T; KUMAR, M. V; MOHNEN, D; Pectin induces apoptosis in human prostate cancer cells: correlation of apoptotic function with pectin structure. Glycobiology vol. 17, n. 8, p. 805-819, 2007.

JUNIOR, J. C. M. de F; SILVA, B. du R. D’A; SOUZA, W. F. de; ARAÚJO, W. M. de; ABDELHAY, E. S. F. W; MORGADO-DÍAZ, J. A. Inhibition of N-linked glycosylation by tunicamycin induces E-cadherin-mediated cell-cell adhesion and inhibits cell proliferation in undifferentiated human colon cancer cells. Cancer Chemother Pharmacol, 2011, 68:227-238.

KLIMOSCH, S. N; FORSTI, A; ECKERT, J; KNEZEVIC, J; BEVIER, M; SCHONFELS, W. von; HEITS, N; WALTER, J; HINZ, S; LASCORZ, J; HAMPE, J; HARTL, D; FRICK, J.-S; HEMMINKI, $\mathrm{K}$; SCHAFMAYER, C; WEBER, A. N. R. Functional TLR5 genetic variants affect human colorectal cancer survival. Cancer Research, 15 de Dezembro de 2013.73 (24).

KOUBALA, B. B; CHRISTIAENS, S; KANSCI, G; VAN LOEY, A. M; HENDRICKX, M. E. Isolation and structural characterization of papaya peel pectin. Food Research International 55 (2014), p. 215-221.

WIENERT, B; WYMAN, S. K; RICHARDSON, C. D; YEH, C. D; AKCAKAYA, P; PORRITT, M. J; MORLOCK, M; VU, J. T; KAZANE, K. R; WATRY, H. L; JUDGE, L. M; CONKLIN, B. R; MARESCA, M; CORN, J. E. Unbiased detection of CRISPR off-targets in vivo using DISCOVER-Seq. Science, 19 de Abril de 2019 - v. 364 (6437), pp. 286-289.

LECLERE, L; CUTSEM, P. V; MICHIELS, C. Anti-cancer activities of pH- or heat-modified pectin. Frontiers in Pharmacology, Outubro de 2013; 4:128.

LEVINE, J. S; AHNEN, D. J. Adenomatous Polyps of the Colon. New England Journal of Medicine., 2006, v. 355, p. $2551-2557$.

LIU, L; LI, Y. H; NIU, Y. B; SUN, Y; GUO, Z. J; LI, Q; LI, C; FENG, J; CAO, S. S; MEI, Q. B. An apple oligogalactan prevents against inflammation and carcinogenesis by targeting LPS/TLR4/NF-Kb pathway in a mouse model of colitis-associated colon cancer. Carcinogenesis vol.31, no.10, p.1822-1832, 2010.

M'SAKNI, N. H; MAJDOUB, H; ROUDESLI, S; PICTON, L; LE CERF, D; RIHOUEY, C; MORVAN, C. Composition, structure and solution properties of polysaccharides extracted from leaves of Mesembryanthenum crystallinum. European Polymer Journal, 2006. 42, 786-795.

MARKOWITZ, S. D; BERTAGNOLLI, M. M. Molecular Basis of Colorectal Cancer. New England Journal of Medicine, 2009; v. 361, p. $2441-2460$. 
MARKOWSKA, A. I; LIU F-T; PANJWANI, N. Galectin-3 is an important mediator of VEGFand bFGF-mediated angiogenic response. J. Exp. Med. Vol. 207, 16 de Agosto de 2010, n. 9, P. 1981-1993.

MATSUNAGA, N; TSUCHIMORI, N; MATSUMOTO, T; II, M. TAK-242 (Resatorvid), a SmallMolecule Inhibitor of Toll-Like Receptor (TLR) 4 Signaling, Binds Selectively to TLR4 and Interferes with Interactions between TLR4 and Its Adaptor Molecules. Mol Pharmacol 79, 2011, p. 34-41.

MAXWELL, E. G; COLQUHOUN, I. J; CHAU, H. K; HOTCHKISS, A. T; WALDRON, K. W; MORRIS, V. J; BELSHAW, N. J. Modified sugar beet pectin induces apoptosis of colon cancer cells via an interaction with the neutral sugar side-chains. Carbohydrate Polymers 136 (2016), p. 923-929.

MAXWELL, E. G; COLQUHOUN, I. J; CHAU, H. K; HOTCHKISS, A. T; WALDRON, K. W; MORRIS, V. J; BELSHAW, N. J. Rhamnogalacturonan I containing homogalacturonan inhibits colon cancer cell proliferation by decreasing ICAM1 expression. Carbohydrate Polymers 132 (2015), p. 546-553.

MAZURECK, N; BYRD, J. C; SUN, Y; HAFLEY, M; RAMIREZ, K; BURKS, J; BRESALIER, R. S. Cell-surface galectin-3 confers resistance to TRAIL by impeding trafficking of death receptors in metastatic colon adenocarcinoma cells. Cell Death and Differentiation, 2012, vol. 19 , p. 523-533.

MORRIS, S; AHMAD, N; ANDRÉ, S; KALTNER, H; GABIUS, H-J; BRENOWITZ, M; BREWER,

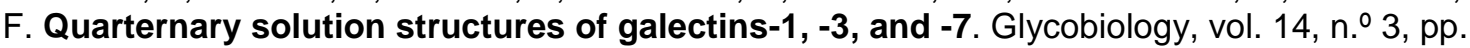
$293-300,2004$.

NANGIA-MAKKER, P; HOGAN, V; HONJO, Y; BACCARINI, S; TAIT, L; BRESALIER, R; RAZ, $A$. Inhibition of human cancer cell growth and metastasis in nude mice by oral intake of modified citrus pectin. Journal of the National Cancer Institute, 18 de Dezembro de 2002. v. 94, n. 24.

NEWLACZYL, A. U; YU, L-G. Galectin-3 - A jack-of-all-trades in cancer. Cancer Letters 313 (2011), p. 123-128.

NEWTON, K; MANNING, G. Necroptosis and Inflammation. Annual Reviews. 1 de Fevereiro de 2016.

OLANO-MARTIN, E; RIMBACH, G. H; GIBSON, G. R; RASTALL, R. A. Pectin and Pecticoligosaccharides induce apoptosis in in vitro human colonic adenocarcinoma cells. Anticancer Research, 23: 341-346 (2003).

ORTEGA-GONZÁLEZ, M; OCÓN, B; ROMERO-CALVO, I; ANZOLA, A; GUADIX, E; ZARZUELO, A; SUÁREZ, M. D; MEDINA, F. S. de; MARTÍNEZ-AUGUSTIN, O. Nondigestible oligosaccharides exert nonprebiotic effects on intestinal epithelial cells enhancing the immune response via activation of TLR4-NFKB. Mol. Nutr. Food Res. 2014, 58, 384-393.

PERES, C. M; CURI, R. Como cultivar células. 1를 edição. Rio de Janeiro: Guanabara-Koogan S.A., 2005.

PRADO, S. B. R. do; CASTRO-ALVES, V. C; FERREIRA, G. F; FABI, J. P. Ingestion of Nondigestible carbohydrates from plant-source foods and decreased risk of colorectal cancer: a review on the biological effects and the mechanisms of action. Frontiers in nutrition, Maio de 2019a; 6:72

PRADO, S. B. R. do; FERREIRA, G. F; HARAZONO, Y; SHIGA, T. M; RAZ, A; CARPITA, N. C; $F A B I$, J. $P$. Ripening-induced chemical modifications of papaya pectin inhibit cancer cell proliferation. Scientific Reports, 2017. 
PRADO, S. B. R. do; MELFI, P. R; CASTRO-ALVES, V. C; BROETTO, S. G; ARAÚJO, E. S; NASCIMENTO, J. R. O. do; FABI, J. P. Physiological Degradation of Pectin in Papaya Cell Walls: Release of Long Chains Galacturonans Derived from Insoluble Fractions during Postharvest Fruit Ripening. Frontiers in Plant Science, July 2016, vol. 7.

PRADO, S. B. R. do; SANTOS, G. R. C; MOURÃO, P. A. S; FABI, J. P. Chelate-soluble pectin fraction from papaya pulp interacts with galectin- 3 and inhibits colon cancer cell proliferation. International Journal of Biological Macromolecules, Abril de 2019c. V. 126; pp 170-178.

PRADO, S. B. R. do; SHIGA, T. M; HARAZONO, Y; HOGAN, V. A; RAZ, A; CARPITA, N. C; $\mathrm{FABI}, \mathrm{J}$. $\mathrm{P}$. Migration and proliferation of cancer cells in culture are differentially affected by molecular size of modified citrus pectin. Carbohydrate Polymers 211 (2019b), 141-151.

REIS, A; HORNBLOWER, B; ROBB, B; TZERTZINIS, G. CRISPR/Cas9 \& Targeted Genome Editing: New Era in Molecular Biology. New England Biolabs - Issue I, 2014.

SANTA CRUZ BIOTECHNOLOGY, INC. CRISPR KO Transfection Protocol. Disponível em: $<$ http://datasheets.scbt.com/CRISPR_protocol.pdf>. Acesso em: 03 de Junho de 2016.

SATHISHA, U. V; JAYARAM, S; NAYAKA, M. A. H; DHARMESH, S, M. Inhibition of galectin3 mediated cellular interactions by pectic polysaccharides from dietary sources.

Glycoconj J (2007) 24, p.497-507.

SHIGA, T. M; FABI, J. P; NASCIMENTO, J. R. O; PETKOWICZ, C. L. de O; VRIESMANN, L. C; LAJOLO, F. M; CORDENUSI, B. R. Changes in Cell Wall Composition Associated to the Softening of Ripening Papaya: Evidence of Extensive Solubilization of Large Molecular Mass Galactouronides. J. Agric. Food Chem. 2009, 57, p. 7064-7071

SIEGEL, R. L; MILLER, K. D; JEMAL, A. Cancer Statistics, 2015. CA Cancer J. Clin. 2015; vol. 65 , p. 5-29.

STREETLY, M. J; MAHARAJ, L; JOEL, S; SCHEY, S. A; GRIBBEN, J. G; COTTER, F. E. GCS100, a novel galectin-3 antagonist, modulates MCL-1, NOXA, and cell cycle to induce myeloma cell death. BLOOD, 13 de maio de 2010 - volume 115, n. 19, p. 3939 - 3948.

STRUM, W. B. Colorectal Adenomas. New England Journal of Medicine, 2016; v. 374, p. 1065 -1075 .

SUZUKI, M; HISAMATSU, T; PODOLSKY, D. K. Gamma Interferon Augments the Intracellular Pathway for Lipopolysaccharide (LPS) Recognition in Human Intestinal Epithelial Cells through Coordinated Up-Regulation of LPS Uptake and Expression of the Intracellular Toll-Like Receptor 4-MD-2 Complex. Infection and Immunity, Junho de 2003, p. 3503-3511.

TABUSA, H; BROOKS, T; MASSEY, A. J. Knockdown of PAK4 or PAK1 Inhibits the Proliferation of Mutant KRAS Colon Cancer Cells Independently of RAF/MEK/ERK and PI3K/AKT Signaling. Molecular Cancer Research, 11 (2), Fevereiro de 2013.

TYCKO, J; HESS, G. T; JENG, E. E; DUBREUIL, M; BASSIK, M. C. The expanding CRISPR toolbox. Nature Methods. 2017

VOGT, L. M; SAHARABUDHE, N. M; RAMASAMY, U; MEYER, D; PULLENS, G; FAAS, M. M; VENEMA, K; SCHOLS, H. A; VOS, P. de. The impact of lemon pectin characteristics on TLR activation and T84 intestinal epithelial cell barrier function. Journal of functional foods, 2016, v. 22, p. 398-407. 
WU, K-L; HUANG, E-Y; JHU, E-W; HUANG, Y-H; SU, W-H; CHUANG, P-C; YANG, K. D. Overexpression of galectin-3 enhances migration of colon cancer cells related to activation of the K-Ras-Raf-Erk1/2 pathway. J Gastroenterol, 2013, 48, p.350-359.

ZHANG, X-H; TEE, L. Y; WANG, X-G; HUANG, Q-S; YANG, S-H. Off-target Effects in CRISPR/Cas9-mediated Genome Engineering. Molecular Therapy-Nucleic Acids, 2015 - 4, e264.

ZHAO, L; KWON, M-J; HUANG, S; LEE, J. Y; FUKASE, K; INOHARA, N; HWANG, D. H. Differential Modulation of Nods Signaling Pathways by Fatty Acids in Human Colonic Epithelial HCT116 Cells. The Journal of Biological Chemistry, 20 de Abril de 2007, vol. 282, n. 16, p. 11618-11628. 